Illinois State University

ISU ReD: Research and eData

Theses and Dissertations

3-16-2021

\title{
"Natural Ties For Patriotic Purposes": The Committee On Public Information, Americanization, And Swedish-American Transnationalism
}

\author{
Race L. Fisher \\ Illinois State University, fisherrace@gmail.com
}

Follow this and additional works at: https://ir.library.illinoisstate.edu/etd

Part of the European Languages and Societies Commons, and the United States History Commons

\section{Recommended Citation}

Fisher, Race L., "'Natural Ties For Patriotic Purposes": The Committee On Public Information, Americanization, And Swedish-American Transnationalism" (2021). Theses and Dissertations. 1367. https://ir.library.illinoisstate.edu/etd/1367

This Thesis is brought to you for free and open access by ISU ReD: Research and eData. It has been accepted for inclusion in Theses and Dissertations by an authorized administrator of ISU ReD: Research and eData. For more information, please contact ISUReD@ilstu.edu. 


\section{"NATURAL TIES FOR PATRIOTIC PURPOSES": THE COMMITTEE ON PUBLIC INFORMATION, AMERICANIZATION, AND SWEDISH-AMERICAN \\ TRANSNATIONALISM}

\section{RACE L. FISHER}

\section{Pages}

The Committee on Public Information (CPI) was the official propaganda agency of the United States during the First World War, seeking to homogenize American public opinion and spread American ideals across the globe. Through a case study of Edwin Björkman's work among Swedish Americans, this thesis illuminates how the CPI approached its work among immigrants, engaging questions of Americanization and transnationalism. Through an analysis of the John Ericsson League of Patriotic Service and the Scandinavian Bureau — both its domestic and foreign operations - this thesis argues that Edwin Björkman and the CPI promoted cultural pluralism rather than assimilation to a dominant Anglo-American culture. Central to this was a distinction between nationality and ethnicity. Though Björkman wanted Swedish Americans to cement their political loyalty to the United States, this did not imply the abandonment of their Swedish cultural identity. Furthermore, this study reveals the complexity of Swedish Americans' transnational ties to Sweden, as they were both influenced by and influenced public and political opinion abroad. Björkman coopted the circulatory transnational relationship between homeland Swedes and Swedish Americans for the American war effort. Serving as agents, objects, and subjects of propaganda, Swedish Americans used their "natural ties for patriotic purposes," organizing themselves along ethnic lines to affirm their loyalty, support the war, and sway the 
public opinion of their countrymen abroad in favor of the United States, its war aims, and its postwar vision of a peaceful and democratic world.

KEYWORDS: Committee on Public Information, Swedish-American history, ScandinavianAmerican history, propaganda, Edwin Björkman, transnationalism 
"NATURAL TIES FOR PATRIOTIC PURPOSES": THE COMMITTEE ON PUBLIC INFORMATION, AMERICANIZATION, AND SWEDISH-AMERICAN

TRANSNATIONALISM

RACE L. FISHER

A Thesis Submitted in Partial Fulfillment of the Requirements

for the Degree of

MASTER OF ARTS

Department of History

ILLINOIS STATE UNIVERSITY

2021 
(C) 2021 Race L. Fisher 
"NATURAL TIES FOR PATRIOTIC PURPOSES": THE COMMITTEE ON PUBLIC INFORMATION, AMERICANIZATION, AND SWEDISH-AMERICAN

TRANSNATIONALISM

RACE L. FISHER

COMMITTEE MEMBERS:

Ross Kennedy, Chair

Christine Varga-Harris 


\section{ACKNOWLEDGMENTS}

I am grateful to the Luther College Dean's Office and Dr. Richard Mtisi for providing the funding to travel to the National Archives in College Park, Maryland to collect documents which constitute the very heart of this thesis. I am thankful for Dr. Ross Kennedy and Dr. Christine Varga-Harris for their guidance, counsel, and insight through the writing process. Thanks to Dr. Anna Peterson for first setting me on the path of this project, advising me in its first iteration, and encouraging me to take it as far as I could. Thanks to Dr. Maren Johnson and Kari Grønningsæter for providing me with the Scandinavian language skills vital to this research and fostering my interest in Scandinavian culture and history. Thanks to my parents for their love and support throughout this academic adventure, and thanks to the boys for the conversations and laughs along the way.

R. L. F. 


\section{CONTENTS}

Page

ACKNOWLEDGMENTS

$\begin{array}{ll}\text { CONTENTS } & \text { ii }\end{array}$

FIGURES iv

$\begin{array}{ll}\text { CHAPTER I: INTRODUCTION } & 1\end{array}$

CHAPTER II: HISTORY OF SWEDISH IMMIGRATION TO 1917

$\begin{array}{ll}\text { Early Immigration } & 10\end{array}$

Urbanization, Professionalization, and Institutionalization 14

$\begin{array}{ll}\text { Creation of a Swedish-American Identity } & 15\end{array}$

$\begin{array}{ll}\text { Swedish Americans During WWI, 1914-17 } & 19\end{array}$

$\begin{array}{ll}\text { Conclusion } & 22\end{array}$

CHAPTER III: OVERVIEW OF THE COMMITTEE ON PUBLIC INFORMATION 23

CHAPTER IV: BACKGROUND ON EDWIN BJÖRKMAN 29

CHAPTER V: THE CPI AND AMERICANIZATION 43

CHAPTER VI: THE JOHN ERICSSON LEAGUE OF PATRIOTIC SERVICE 53

$\begin{array}{ll}\text { Organizational Structure } & 54\end{array}$

$\begin{array}{ll}\text { Expansion of the League } & 56\end{array}$

Björkman and the League's Message: Nationality vs. Ethnicity 59

Activities of the League $\quad 64$

$\begin{array}{ll}\text { Conclusion } & 70\end{array}$

CHAPTER VII: THE CPI, JELPS, AND THE FOURTH OF JULY 1918

$\begin{array}{ll}\text { Background on the Celebration } & 73\end{array}$ 
$\begin{array}{ll}\text { Björkman Cancels Midsummer } & 75\end{array}$

$\begin{array}{ll}\text { The New York Parade } & 76\end{array}$

$\begin{array}{lr}\text { Conclusion } & 83\end{array}$

CHAPTER VIII: THE SCANDINAVIAN BUREAU, PRESS WORK AND CENSORSHIP 85

$\begin{array}{ll}\text { Press Work } & 87\end{array}$

Björkman and the Censorship of the Swedish-American Press 94

$\begin{array}{ll}\text { Björkman and the Augustana Synod } & 100\end{array}$

$\begin{array}{ll}\text { Conclusion } & 104\end{array}$

$\begin{array}{ll}\text { CHAPTER IX: THE SCANDINAVIAN BUREAU ABROAD } & 107\end{array}$

$\begin{array}{ll}\text { Palmer's Stockholm Office } & 115\end{array}$

CHAPTER X: CONTENT OF THE BUREAU'S FOREIGN PROPAGANDA 123

$\begin{array}{ll}\text { General Propaganda } & 125\end{array}$

$\begin{array}{ll}\text { Scandinavian-American Propaganda } & 128\end{array}$

$\begin{array}{ll}\text { CHAPTER XI: CONCLUSION } & 135\end{array}$

$\begin{array}{ll}\text { BIBLIOGRAPHY } & 145\end{array}$

$\begin{array}{ll}\text { Abbreviations } & 145\end{array}$

$\begin{array}{ll}\text { Primary Sources } & 145\end{array}$

$\begin{array}{ll}\text { Secondary Sources } & 147\end{array}$ 


\section{FIGURES}

Figure

Page

1. Helge Nelson's “Map of the Swedish-Born in North America According to the Census of 1920 in the United States and of 1921 in Canada.” Reproduced from Helge Nelson, The Swedes and the Swedish Settlements in North America, Vol. II (New York: Arno Press, 1979), 4.

2. George Creel. Signal Corps, Photograph No. 111-SC-184, "George Creel, Chairman of the Committee on Public Information," Photographs of American Military Activities, ca. 1918-ca. 1981, RG 111, NACP

3. Edwin Björkman, July 1918. Photograph No. 165-WW-134A-3, “Edwin Björkman, Director, Scandinavian Bureau, Committee on Public Information,” July 1918, Committee on Public Information - Personnel, American Unofficial Collection of World War I Photographs, 1917-1918. RG 165, NACP.

4. "The Sunday News War Map," The Sunday News, 1914. Courtesy of the David Rumsey Historical Map Collection, David Rumsey Map Center, Stanford Libraries. 
5. Jonas Lie, "Roald Amundsen, Discoverer of the South Pole, Direct from American Trenches," poster, 1918. Reproduced from The AmericanScandinavian Review 6, no. 3, (May-June 1918), 150, digitized by Google. The caption states that Roald Amundsen "lectured throughout the country" as "the guest of our government." This poster, painted by Norwegian-American artist Jonas Lie, advertised a lecture at the Century Theater in New York on March 17.

6. The Swedish-American float depicting the colonists of New Sweden in the New York parade, July 4, 1918. Und. \& Und., 165-WW-72D-8, “July 4th Parade on Fifth Avenue, New York City. Swedish float in the parade. More than forty-two nations were represented in parade," July 4, 1918, Ceremonies - Independence Day, 1918, 1917-1918, American Unofficial Collection of World War I Photographs, 1917-1918, RG 165, NACP.

7. Swedish Americans wearing traditional folk dress in the New York parade, July 4, 1918. Und. \& Und., 165-WW-72D-82, "The Swedish Section in the Independence Day Parade, New York City, July 4, 1918,” July 4, 1918. Ceremonies - Independence Day, 1918, 1917-1918, American Unofficial Collection of World War I Photographs, 1917-1918, RG 165, NACP.

8. Lt. Edward B. Robinette, 1914. Courtesy of "United States Passport Applications, 1795-1925," FamilySearch, M1490, Passport Applications, January 2, 1906 - March 31, 1925, roll 227, 1914 Nov-Dec, certificate no 44334-45100, image 197; citing NARA microfilm publications M1490 and M1372. 
9. Eric H. Palmer. Reproduced from Brooklyn Press Club: About Ourselves, By Ourselves, 1912-1922, ed. by the Brooklyn Press Club (Brooklyn: Brooklyn Press Club, 1922), 11. 


\section{CHAPTER I: INTRODUCTION}

As Allied forces prepared to defend against the final German offensive of the First World War in early July 1918, Hjalmar Branting, leader of the Swedish Social Democrats, said in an interview in Paris, "I am pleased to know that among the Americans who are in France there are a great number of Swedish descent. I have always thought it necessary to reunite the bond between Swedes in Sweden and Swedes in America. I hope the stand Swedish-Americans are taking will influence opinion in my country."1 By the end of July, the statement appeared throughout the Swedish-American press nationwide, showing Swedish Americans that their sacrifices made in the name of democracy had the power to inspire reform and strengthen the bond between the New and Old Country. ${ }^{2}$ This moving remark by one of Sweden's leading politicians did not appear in the Swedish-American press organically, but rather was disseminated by the Scandinavian Bureau of America's wartime propaganda organization, the Committee on Public Information (CPI).

The Scandinavian Bureau, under the leadership of Swedish-American journalist, translator, and literary critic Edwin Björkman, sought first to instill in America’s Swedish immigrant population an unwavering loyalty to their adopted nation and its war aims. Björkman then expanded the Bureau abroad, establishing American press offices in the Swedish and Danish capitals in order to combat pervasive German propaganda and win over the Scandinavian people to American liberal-democratic ideals.

The Committee on Public Information was significant in that it was the United States' first large-scale propaganda agency with offices spanning the globe. The CPI sought to

\footnotetext{
${ }^{1}$ Palmer to Björkman, telegram, 5 July 1918, file 103.93/470, CDF.

${ }^{2}$ Edwin Björkman wrote that the statement was sent "to the entire Swedish-American press." Edwin Björkman to Eric H. Palmer, August 14, 1918, entry 106, box 16-17, CPI. Examples include: "Ett uttalande af Hjalmar Branting," Nordstjernan, July 19, 1918, 2; "Ny Brantingsintervju," Svenska tribunen-nyheter, July 24, 1918, 1; "Sverige Sympatiserar med demokratien” Svea, July 24, 1918, 4; and Svenska amerikanaren, July 25, $1918,1$.
} 
homogenize American public opinion, encourage patriotic contribution to the war effort, and win support for President Woodrow Wilson's post-war goals articulated in his Fourteen Points. The Committee further sought to educate foreign populations about the realities of life in America, its military and industrial strength, its leading role in innovation and progress, and its president's vision for a peaceful, democratic world. Such an ambitious mission necessitated engaging every possible demographic through all forms of media. Widespread immigration to the United States around the turn of the century created a multiplicity of groups of diverse beliefs and backgrounds and thus posed a great obstacle to the CPI's vision of a nation imbued with the ideals of Americanism. This fact begs the question: how did the Committee on Public Information approach its work among immigrants? How did they view Americanization? How did the CPI negotiate immigrants' transnational ties to their homelands?

In the chapter "Propaganda: Wilson and the Committee on Public Information," Dr. Richard L. Hughes identifies the numerous angles historians have taken in their approach to understanding the work of the Committee on Public Information: their reliance on voluntarism or coercion, their relationship with Progressive Era reform, their ties to educational institutions and the American film industry, and their work among individual groups such as women, workers, and African Americans. ${ }^{3}$ The broad scope of the CPI's work divided up by various divisions and bureaus allows for a multitude of scholarly approaches, and numerous books and articles have made the organization a well-studied topic. Despite having a Foreign Language Newspaper Division and Division of Work with the Foreign Born, there has yet to be a study dedicated to the Committee's work among America's immigrant population. This being said, historians have touched on questions regarding the CPI's work with immigrants.

\footnotetext{
${ }^{3}$ Richard L. Hughes, "Propaganda: Wilson and the Committee on Public Information," in A Companion to Woodrow Wilson, ed. Ross A. Kennedy (Chichester, West Sussex: Wiley-Blackwell, 2013): 308-322.
} 
The first question pertains to the CPI's approach toward Americanization. By way of defining the term, Milton Gordon identifies three different models of Americanization. The first is the Anglo-conformity model, where immigrants must abandon all traces of ethnicity and embrace a dominant Anglo-American Protestant norm. Second is the melting pot model, which alleges that a distinctly American identity is forged through the amalgamation of various peoples, cultures, and traditions. The third is cultural pluralism, which demanded political allegiance to American democratic institutions, fluency in English, and naturalization, but allowed for the retainment of an ethnic cultural identity. Advocates around the turn of the century such as Horace Kallen and John Dewey argued that ethnic diversity had value, as it enriched American culture through the introduction of new traditions. ${ }^{4}$ Did the CPI promote Anglo-American cultural homogeneity, the melting pot, or cultural pluralism?

James R. Mock and Cedric Larson argued in Words that Won the War, that the CPI was "a social innovation brilliantly conceived and in many ways brilliantly executed." The committee's chairman, George Creel, largely "withstood the temptation to dictatorship" despite wielding unprecedented censorship power and used his position justly to homogenize American public opinion. ${ }^{6}$ Mock and Larson's characterization of the CPI's Division of Work with the Foreign Born is seen in a similar light. Though the CPI used the coercive power of the Trading with the Enemy Act to compel the loyalty of the foreign-language press, they relied more so on the "education" of immigrants through the distribution of pamphlets, flooding the foreignlanguage press with CPI material, and encouraging participation in ethnic patriotic leagues. ${ }^{7}$

\footnotetext{
${ }^{4}$ Desmond King, Making Americans: Immigration, Race, and the Origins of the Diverse Democracy (Cambridge: Harvard University Press, 2000), 85, 29.

${ }^{5}$ James R. Mock and Cedric Larson, Words That Won the War: The Story of the Committee on Public Information, 1917-1919 (Princeton: Princeton University Press, 1939), 338.

${ }^{6}$ Mock and Larson, Words That Won the War, 338.

${ }^{7}$ Mock and Larson, Words That Won the War, 216.
} 
From Mock and Larson's assessment, it is difficult to gauge the goal of the CPI's efforts beyond cementing immigrant loyalty and creating support for the war.

In Holding Fast the Inner Lines, Stephen Vaughn argues that the CPI, staffed with "liberal, reform-minded journalists and intellectuals," was emblematic of the Progressive Era. ${ }^{8}$ The committee sought to reform society and strengthen democracy through the promotion of American nationalism. The Progressive leaders of the CPI saw American nationalism—rooted in the ideals of democracy, individual liberty, and human equality — as a secular religion capable of bringing the nation together under a shared ideology. Vaughn states that “converting” America's immigrants was a chief obstacle in this nationalizing process. ${ }^{9}$ Through their National School Service, the CPI encouraged immigrants to abandon "Old World ways," naturalize, and learn English, while also encouraging "native" Americans to aid their integration into American life through tolerance and mutual understanding. While Vaughn remains rather vague on the nature of CPI Americanization, he indicates that the goal of immigrant education was practical— that is, economic and political-rather than cultural, meaning that the Committee was more tolerant and less focused on cultural assimilation than other wartime Americanizing efforts. ${ }^{10}$

In his work on the history of American nativism, Strangers in the Land, John Higham places the CPI within the tradition of liberal Progressivism. He writes that while the CPI engaged in the process of Americanization, their approach was unique in that they sought to showcase immigrant "gifts," or contributions to the building of the United States and gave them a sense of participation in the nation's cause. ${ }^{11}$ Though he does not apply the term himself, his assessment

\footnotetext{
${ }^{8}$ Stephen Vaughn, Holding Fast the Inner Lines: Democracy, Nationalism, and the Committee on Public Information (Chapel Hill: University of North Carolina Press, 1980), 37.

${ }^{9}$ Vaughn, Holding Fast the Inner Lines, 49.

${ }^{10}$ Vaughn, Holding Fast the Inner Lines, 105-7.

${ }^{11}$ John Higham, Strangers in the Land: Patterns of American Nativism, 1860-1925 (New Brunswick: Rutgers University Press, 1988), 216, 247, 252-3.
} 
seems to identify the CPI with support for cultural pluralism. In response to Higham's view of the CPI's liberal Progressivism, David M. Kennedy argues in Over Here that despite holding this ideology, "homogeneity remained the ideal" for George Creel. The CPI's goal was not "pluralism" but to "root out ethnic peculiarity," which was a sentiment shared by "even the most liberal Americanizers." ${ }^{12}$ The distinction between the CPI's work from more aggressive assimilation was merely a matter of "tactics" rather than "ultimate goal." 13

Historians of Scandinavian-American immigration also tend to place the CPI's work among the foreign born within the context of wartime repression and Americanization. Sture Lindmark described the CPI as "an intensely organized program of indoctrination" with the head of its Scandinavian Bureau, Edwin Björkman, characterized as someone concerned only with "rank, title, position, and authority," who unjustly censored and harassed the press, threw around accusations of disloyalty, and urged Swedes to abandon the Swedish language. ${ }^{14} \mathrm{H}$. Arnold Barton simply characterized Björkman as a proponent of "100\% Americanism."15

Coming to the defense of the Committee's pluralistic motives, Robyn Muncy argues in Relentless Reformer, a biography of Josephine A. Roche, director of the CPI's Division of Work with the Foreign Born, that Roche's "work at the CPI, an agency often associated with wartime repression, furthered the cause of democracy and cultural diversity, as she created a forum in which immigrant groups represented themselves to the federal government and a larger American public even as her agency tried to recruit immigrants to U.S. war aims." 16

\footnotetext{
${ }^{12}$ David M. Kennedy, Over Here: The First World War and American Society (New York: Oxford University Press, 1980), 66.

${ }^{13}$ Kennedy, Over Here, 65-66.

${ }^{14}$ Sture Lindmark, Swedish America, 1914-1932: Studies in Ethnicity with Emphasis on Illinois and Minnesota (Stockholm: Läromedelsförlaget, 1971), 109-10.

${ }^{15}$ H. Arnold Barton, A Folk Divided: Homeland Swedes and Swedish Americans, 1840-1940 (Carbondale: Southern Illinois University Press, 1994), 247.

${ }^{16}$ Robyn Muncy, Relentless Reformer: Josephine Roche and Progressivism in Twentieth-Century America (Princeton: Princeton University Press, 2014), 102.
} 
To a lesser extent, scholars have also observed a transnational element to the CPI's domestic work among immigrants and their efforts in foreign nations. The theory of transnationalism pertains to the ways in which immigrants retain meaningful ties to their homeland after settling in a new country. Thomas Faist defines this phenomenon through his concept of a "transnational social space," which contains "combinations of social and symbolic ties, positions in networks and organizations, and networks of organizations that can be found in at least two geographically and internationally distinct places." 17 These networks—whether personal, community, business, or organizational—facilitate an asymmetrical, two-way circulation of ideas, symbols, and material goods between immigrants and their homeland, creating a system of social and symbolic ties that transcend territorial boundaries. ${ }^{18}$ The immigrant, in turn, develops a hybrid identity which contains cultural elements of both places.

Hints of the CPI engaging immigrants' transnational ties to their homeland appear in studies of both their domestic and foreign work. James R. Mock and Cedric Larson noted the Scandinavian Bureau's employment of propaganda detailing the activities of Swedish-Americans abroad, pointing out that Edwin Björkman's domestic activities as well as “the numerous contacts between Sweden and America" facilitated such work. ${ }^{19}$ David M. Kennedy stated in Over There that so strong was Creel's desire to Americanize that the CPI "mobilized American ethnic groups to carry propaganda back to their European homelands," with Creel remarking how immigrants made the "best propagandists" abroad. ${ }^{20}$ Lastly, Daniela Rossini's study of the CPI in Italy, Woodrow Wilson and the American Myth in Italy, comes the closest to revealing the

\footnotetext{
17 Thomas Faist in Peter Kivisto, "Theorizing transnational immigration: a critical review of current efforts," Ethnic and Racial Studies 24, no. 4 (July 2001): 567.

18 Thomas Faist, "Diaspora and Transnationalism: What Kind of Dance Partners?," in Diaspora and

Transnationalism: Concepts, Theories, and Methods, ed. Rainer Bauböck and Thomas Faist (Amsterdam: Amsterdam University Press, 2010): 29.

${ }^{19}$ Mock and Larson, Words That Won the War, 279.

${ }^{20}$ Kennedy, Over Here, 65-66.
} 
relationship between immigrant transnationalism and the CPI's foreign work. In her first chapter, she argues that Italian-American letters to friends and relatives back in Italy before the war created the "myth of America" and spread American ideals, which ultimately formed a foundation for the CPI's propaganda. ${ }^{21}$ She also discussed the employment of Italian-Americans as arbiters of propaganda, but because the focus of the study was on Italy, a link between the domestic work among Italian Americans and the foreign work was absent. ${ }^{22}$

By placing the CPI within the context of American immigration history, this thesis intends to provide greater insight into the ways in which the CPI went about organizing and Americanizing immigrants through a case study of Edwin Björkman's work among Swedish Americans. Through an analysis of the John Ericsson League of Patriotic Service and the Scandinavian Bureau — both its domestic and foreign operations - this thesis argues that Edwin Björkman and the CPI promoted cultural pluralism.

Björkman's portrayal by Scandinavian-American historians solely as an Americanizer does not capture the nuance of the Scandinavian Bureau's work, as he emphasized a distinction between one's ethnicity and nationality. Though he was anxious for Swedish Americans to make clear their loyalty to the United States and abandon their political allegiance to Sweden, Björkman's efforts did not imply the abandonment of Swedish cultural identity in America. The CPI's work among America's foreign born was a Progressive reaction to the nativism and chauvinism of the popular Americanization campaign, advocating for cultural pluralism and organic assimilation. While Björkman pressed for an unwavering loyalty to the United States, the learning of English, and naturalization, he communicated his message through the Swedish language, Swedish-American organizations, and their ethnic leadership. Furthermore, Björkman

\footnotetext{
${ }^{21}$ Daniela Rossini, Woodrow Wilson and the American Myth in Italy: Culture, Diplomacy, and War Propaganda (Cambridge: Harvard University Press, 2008), 25-29.

${ }^{22}$ Rossini, Woodrow Wilson and the American Myth in Italy, 106-11.
} 
affirmed ethnic affiliations by organizing their patriotic activity along ethnic lines, organizing aid for Swedish-American troops, and highlighting Scandinavian contributions to the building of the United States. In this way, Edwin Björkman encouraged the persistence of Swedish-American ethnic identity during the war. The use of Swedish Americans' "natural ties for patriotic purposes" was not limited to one side of the Atlantic. ${ }^{23}$

In his work for the CPI, Edwin Björkman encouraged and capitalized on transnational relationships between Swedish Americans and Swedes in Sweden. This aspect of Björkman's work was built on the assumption that Swedish Americans were influenced by political, social, and cultural developments in Sweden through the news and information they received. Björkman also believed the opposite to be the case, that Swedes could be influenced by the beliefs and actions of its emigrant population gleaned from statements by its leading figures, personal correspondence, and news regarding their loyalty and intense patriotic activity. It was Björkman's objective to coopt this circulatory transnational relationship between homeland Swedes and Swedish Americans for the American war effort. By strengthening the bonds between these two populations, Björkman hoped to spread democracy and strengthen support for President Woodrow Wilson's program of international reform, as well as facilitate mutual understanding and cultural exchange between the United States and Sweden.

Serving as agents, objects, and subjects of propaganda, Björkman encouraged Swedish Americans to use their "natural ties for patriotic purposes," organizing themselves along ethnic lines to affirm their loyalty, support the war, and sway the public opinion of their countrymen abroad in favor of the United States, its war aims, and its postwar vision of a peaceful and democratic world.

\footnotetext{
${ }^{23}$ Edwin Björkman, “Confidential circular \#2,” April 29, 1918, entry 105, box 4-5, CPI.
} 


\section{CHAPTER II: HISTORY OF SWEDISH IMMIGRATION TO 1917}

The Committee on Public Information organized its Scandinavian Bureau first to Americanize the United States' sizeable Swedish immigrant population, and second to propagate American ideas in Sweden. To accomplish this task, the Bureau engaged an existing network of Swedish-American organizations, a Swedish-American ethnic leadership, and links between immigrants and their homeland. By 1914, this organizational and transnational infrastructure was firmly in place. For this reason, it is relevant to survey the history of Swedish immigration to America.

First, this chapter will discuss the push and pull factors that caused Swedes to emigrate in the mid- to late nineteenth century, Swedish settlement patterns, and population statistics. Immigrant "America letters" were early signs of a transnational relationship between Swedish Americans and Swedes in Sweden, as they encouraged Swedes to emigrate, provided a critique of Swedish society, and spread American ideals in Sweden. Swedish Americans had their "heyday" from 1890-1914, reaching a high degree of organization across the United States. The establishment of Swedish-American religious and secular institutions facilitated the creation of a distinct Swedish-American identity by the emerging ethnic leadership. Cultural figureheads discussed the importance of preserving Swedish culture in America and pursued academic and cultural exchange with Sweden. Lastly, this chapter discusses the difficulties Swedish Americans faced during the first years of World War I amidst calls for "100 per cent Americanism."

This context is essential to understanding the salience of Swedish-American ethnic identity, its far-reaching institutions, its leading cultural and professional citizens, and Swedish America's transnational relationship with Sweden. The work of the CPI's Scandinavian Bureau built upon the existing institutions and transnational culture which was in place upon its creation. 


\section{Early Immigration}

Sustained Swedish immigration to the United States began in the mid-1840s and continued - with interruptions during the Civil War and World War I — until the Johnson-Reed Act of 1924 . From 1850 to 1930 , approximately 1.3 million Swedes immigrated to North America. In raw numbers Swedish immigration was dwarfed by that of Germans, Italians, and the Irish, however when put in terms of the population of the sending country, Sweden placed third behind Ireland and Norway. ${ }^{24}$

The motivations for Swedish immigration to America can be understood as a series of push and pull factors. The image of America as a land of freedom and opportunity appealed to people across Europe seeking religious freedom, economic independence, and social mobility. Many early Swedish immigrant travelled to America for religious freedom. Dissatisfaction with the Swedish state church spurred pietist revivals and led to religious dissidents like Eric Jansson to establish utopian colonies in America. ${ }^{25}$

Swedes looking to improve their material circumstances also looked to the United States. As worldwide transportation networks developed, the United States became more integrated into European agricultural markets. The transportation of goods and people across the Atlantic improved with the rise of the steam ship, lowering the cost and risk of transatlantic travel and allowing American grain to compete in European markets. As railroads expanded across the North American continent, more farmland became available and transcontinental shipping increased in speed and efficiency. As a result, European agriculture faced a crisis, lowering

\footnotetext{
${ }^{24}$ Dag Blanck, The Creation of an Ethnic Identity: Being Swedish American in the Augustana Synod, 1860-1917 (Carbondale: Southern Illinois University Press, 2006), 2.

${ }^{25}$ Barton, A Folk Divided, 15-6. Jansson and his followers founded the utopian colony at Bishop Hill, Illinois in 1846.
} 
farmers' income and economic opportunities in Sweden. ${ }^{26}$ Peasant farmers owning or renting small tracts of land in Sweden were thus drawn to America's expanding frontier.

The Homestead Act of 1862 offered free and cheap farmland in the Midwestern states. Swedish settlements concentrated in western Illinois, Iowa, southern Minnesota, and western Wisconsin. Young, unmarried men, tempted by the prospect of the wealth and status presented by a large American farm, took advantage of innovations in new transportation technology by taking a steamship westward to settle among their countrymen in Midwestern Swedish colonies. A process of "chain migration" occurred as Swedes settled among relatives, friends, or those from the same town or province. Immigrant letters, known as "America letters," played a key role in creating these migratory links. The letters often described life in America in extravagant terms, boasting of vast and fertile farmlands, great wealth, social equality and mobility, the availability of education, and religious and political freedom. Letters were passed among families and friends and were occasionally published in part or whole in provincial newspapers. ${ }^{27}$ In this way the "myth of America" spread among Swedes, infecting them with "America Fever," and convincing them to abandon their families and communities in Sweden for a better life in America, where relatives and friends were waiting for them. ${ }^{28}$

This circulation of ideas about America via immigrant letters marked the beginning of a transnational relationship between Swedish Americans and Swedes in Sweden. The grand descriptions of America as a land of freedom, prosperity, and equality also contained implicit or explicit critiques of life in Sweden. The vast lands in America contrasted with small tenant farms in Sweden; political freedom contrasted limited suffrage; religious freedom contrasted the

\footnotetext{
${ }^{26}$ Barton, A Folk Divided, 37-8; Daron Olson, Vikings Across the Atlantic: Emigration and the Building of a Greater Norway, 1860-1945 (Minneapolis: University of Minnesota Press, 2013), 6-10.

${ }^{27}$ Barton, A Folk Divided, 17.

${ }^{28}$ As stated in the introduction, Daniela Rossini argued in that the "America letters" of Italian immigrants laid the foundation for CPI propaganda in Italy. See Rossini, Woodrow Wilson and the American Myth in Italy, 25-29.
} 
repression of the state church; social mobility and a sense of classlessness contrasted a rigid class structure; and American industrial progress and increased wages contrasted Swedish stagnation. This critique of Sweden spurred not only a desire to emigrate among the peasants, but also broader desire for change within Sweden. Carl Frederik Peterson wrote in Sverige i Amerika (Sweden in America) that America letters "have planted an idea among those who stayed home which in time will make its mark in the Riksdag and bear fruit in new, liberal institutions."29

Furthermore, this critique resulted in introspection within the Swedish government to understand the causes and consequences of mass emigration. The appeal of America had deprived Sweden of physical and intellectual manpower which posed a serious problem for the future of Sweden. Using America as a model, some Swedish officials considered reforms like universal male suffrage, broader education, increased home ownership, and general economic development. In this way, they could "bring America over to Sweden," make Sweden appear as "the land of the future," and thus dissuade further emigration. ${ }^{30}$

The passing of universal male suffrage in 1907 facilitated the rise of the Swedish Social Democrats under Hjalmar Branting, who advocated for further reforms in Sweden, and who was praised by Swedish Americans for seeking to cure the ills which had drove them from their country. ${ }^{31}$ Through this process, Swedish immigration was of transnational significance through the spread of Americanism among the Swedish people via immigrant letters and also in the way that the crisis of mass emigration pushed Swedish officials to pursue democratic reforms.

\footnotetext{
${ }^{29}$ Carl Frederik Peterson in Barton, A Folk Divided, 124. The Riksdag is the Swedish parliament.

${ }^{30}$ Barton, A Folk Divided, 149.

${ }^{31}$ Barton, A Folk Divided, 132; Jørn Brøndal, Ethnic Leadership and Midwestern Politics: Scandinavian Americans and the Progressive Movement in Wisconsin, 1890-1914 (Northfield, MN: Norwegian-American Historical Association, 2004), 228.
} 


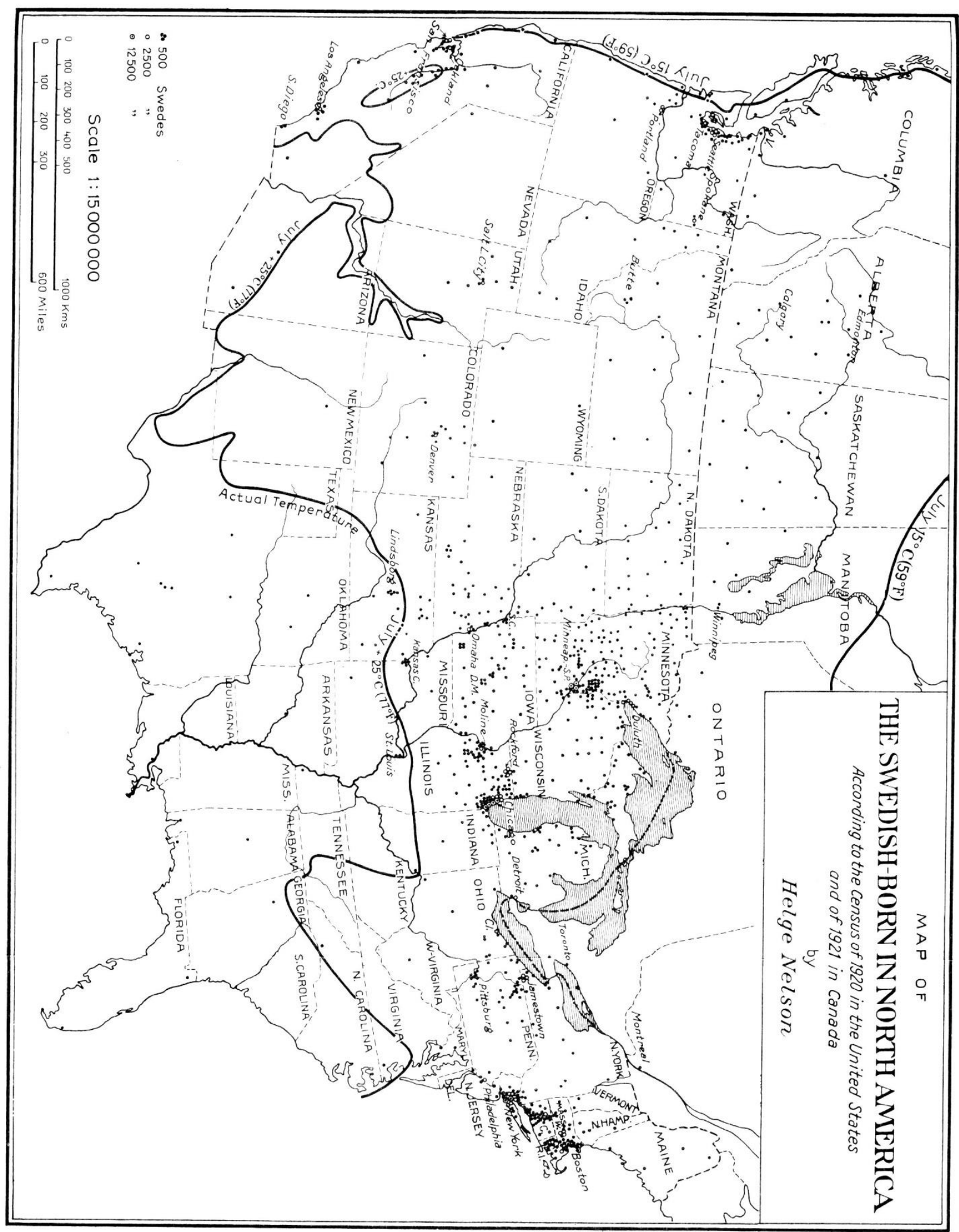

Figure 1: Helge Nelson's "Map of the Swedish-Born in North America According to the Census of 1920 in the United States and of 1921 in Canada." Reproduced from Helge Nelson, The Swedes and the Swedish Settlements in North America, Vol. II (New York: Arno Press, 1979), 4. 


\section{Urbanization, Professionalization, and Institutionalization}

While many Swedes immigrated to the United States as farmers, by the turn of the century Swedes were drawn into the cities, attracted to the new opportunities presented by growing industry. ${ }^{32}$ Swedes dispersed from their Midwestern epicenters, populating cities from coast to coast. Notable cities with large Swedish-American populations include Minneapolis and St. Paul, Minnesota; Jamestown, New York; Worcester, Massachusetts; and Seattle, Washington. In 1910, 100,000 Swedes inhabited Chicago, Illinois, making it home to ten percent of all Swedes in America, as well as the city with the second largest number of Swedes in the world behind Stockholm. ${ }^{33}$

With urbanization came a growing Swedish-American professional middle class of skilled laborers, journalists, lawyers, doctors, and politicians. The presence of large numbers of Swedes in cities also led to the creation of Swedish-American clubs, organizations, and institutions.

From the beginning of Swedish settlement in America, immigrants developed institutions to meet their practical and spiritual needs in the new country. Secular organizations included mutual-aid societies, banks, clubs, choirs, theaters, political organizations, and labor unions. Various Swedish religious groups formed local congregations, hospitals, and benevolent institutions like orphanages and homes for the aged. The Augustana Synod, formed in June 1860, was one of the most organized and prolific Swedish cultural institutions, spawning several colleges, academies, a theological seminary, a publishing house, periodicals, and over one thousand local congregations across the country. In 1915, the Synod boasted 274,000 members. ${ }^{34}$ Lastly, the Swedish-American press played a significant role in providing a source of

\footnotetext{
${ }^{32}$ Blanck, The Creation of an Ethnic Identity, 23.

${ }^{33}$ Blanck, The Creation of an Ethnic Identity, 24.

${ }^{34}$ Blanck, The Creation of an Ethnic Identity, 25.
} 
information for local, national, and world news and served as a space of public discourse within Swedish-American communities. Anywhere from 600 to 1,000 Swedish-language newspapers were published in the United States with a circulation of 650,000 in 1910 , making it the secondlargest foreign-language press in America behind the Germans. ${ }^{35}$ These organizations all served to meet the social, economic, political, and spiritual needs of Swedish-American immigrants who shared a common language, history, traditions, and culture as they adjusted to life in America. Dag Blanck estimates that nearly half a million Swedish Americans - one third of their population - participated in Swedish-American organizations in the 1920s, showing their "high degree of ethnic identification." 36

\section{Creation of a Swedish-American Identity}

It is within the network of Swedish-American organizations and institutions that an ethnic leadership emerged who forged a distinct ethnic identity. Early Swedish immigrants emphasized swift Americanization among their people — to learn English and assimilate into American society as quickly as possible. Erland Carlsson, a founder of the Augustana Synod once said, "that the Swedish language would be dead in America in twenty years, and therefore I prepared myself for the change and studied the English language," a position which was reflected in the curriculum of Augustana College, with an initial push for English to be the primary language of instruction. ${ }^{37}$

By the 1890s, a Swedish-American consciousness began to develop and be articulated by leading Swedish-American cultural figures. Rather than argue for swift Americanization as early Swedish immigrants had done, Swedish-American leaders began seeking to preserve Swedishness - its language, culture, and traditions - in America. Johan Alfred Enander, a

\footnotetext{
${ }^{35}$ Blanck, The Creation of an Ethnic Identity, 26.

${ }^{36}$ Blanck, The Creation of an Ethnic Identity, 27.

${ }^{37}$ Blanck, The Creation of an Ethnic Identity, 59-60.
} 
prolific Swedish-American author, editor of the Swedish-language Chicago newspaper Hemlandet, and public speaker, was a key figure in advocating for the preservation of Swedish culture in America. Enander's writings and speeches on the significance of Sweden and the Swedish people in American history have been classified as homemaking myths by Orm Øverland. Øverland argues in Immigrant Minds, American Identities that around the turn of the century, ethnic leaders created homemaking myths to legitimize their group's belonging in America and to justify the preservation of its culture and traditions, often competing for legitimacy and status with other ethnic groups. ${ }^{38}$ Homemaking myths, generally expressed through amateurish and filiopietistic treatments of history, can be placed into three categoriesmyths of foundation, blood sacrifice, and ideological gifts.

Exemplary of a foundation myth, Enander pointed to the Viking discovery and subsequent colonization of North America, displacing the discovery of Christopher Columbus and providing Swedish Americans with a unique claim to America. ${ }^{39}$ Furthermore, the colony of New Sweden founded in 1638 showed that Swedes colonized the continent alongside the English. Again reaching far back into history, Enander argued that the ideological foundation of the United States—-freedom, legality, and self-governance—originated in Sweden. He argued that the Vikings first introduced these ideas to England, which were then reasserted by the Normans, who were of Viking origin. The Magna Carta of 1215 embodied these ideals and served as a template for the American Constitution. Furthermore, Viking settlement in England

\footnotetext{
${ }^{38}$ Orm Øverland, Immigrant Minds, American Identities: Making the United States Home, 1870-1930 (Urbana: University of Illinois Press, 2000).

${ }^{39}$ The Norwegians claimed Leif Ericsson, the leader of the Viking expedition that discovered North America, solely for themselves while the Swedes identified them as Scandinavians more broadly. Claims of the Viking discovery of North America brought Scandinavians into conflict with the Italians, whose ethnic identity embraced Columbus as a mythological foundational figure. See Øverland, Immigrant Minds, American Identities, 72, 79; Blanck, The Creation of an Ethnic Identity, 163-67.
} 
also provided an argument for a close biological relationship between Anglo-Saxons and Scandinavians.

As examples of blood sacrifice, Enander pointed towards Swedish-American soldiers who fought in the Revolutionary and Civil Wars. Furthermore, Swedish-American homemaking mythology created its own pantheon of heroes. Enander wrote about John Morton, a settler of New Sweden who casted the deciding vote in favor of the Declaration of Independence in Pennsylvania. Other Swedish-Americans pointed to the engineer John Ericsson, whose invention of the Monitor, an ironclad warship equipped with a rotating turret, saved the Union fleet from destruction at the Battle of Hampton Roads during the Civil War. Lastly, Enander and others argued that Swedish immigrants played a key role in settling the expanding frontier as pioneers, bringing civilization to a wild, untamed landscape. ${ }^{40}$

Enander's writings created a Swedish-American mythology, complete with heroes and key events, which took on a life of its own as it was recited and embellished by other SwedishAmerican leaders and was disseminated through the press, speeches, institutions, and organizations.

The articulation of a Swedish-American identity was the recognition that the immigrants possessed a transnational hybrid identity. $\emptyset$ verland makes the important point that the purpose of homemaking myths was not to celebrate a foreign nationality, but to celebrate the group's distinct American identity by espousing its unique contributions and sacrifices to the building of America; while they were of Swedish origin, the heroes of the homemaking myths made their

\footnotetext{
${ }^{40}$ Blanck, The Creation of an Ethnic Identity, 163-67, 175-77; Dag Blanck, "Constructing and Ethnic Identity: The Case of the Swedish-Americans," in The Ethnic Enigma: The Salience of Ethnicity for European-Origin Groups, ed. Peter Kivisto (Philadelphia: The Balch Institute Press, 1989), 142-46; Øverland, Immigrant Minds, American Identities, 126.
} 
sacrifice for America. In a speech in Chicago in 1899, Enander explained that "it has not been Sweden's, but rather Swedish America's cause for which I have above all striven." ${ }^{\prime 1}$

While Swedish-Americans argued for their right to call America their home, they recognized that their cultural identity was still tied to Sweden. Swedish Americans sought to be recognized as legitimate heirs to Swedish culture in America, maintaining cultural contacts and exchange with Sweden to keep their unique identity alive in America. Enander hoped for a "new union between two brother peoples in Sweden and America," based on a common cultural heritage, joining "the best, the noblest our people possesses on both sides of the Atlantic." 42

With the professionalization and institutionalization of an ethnically conscious Swedish America, their transnational relationships with Sweden took on a formal shape. Scandinavian Americans interested in studying their heritage as well as Anglo-Americans interested in Old Norse language and Viking history established educational institutions to facilitate academic study and exchange between the United States and Scandinavia. In 1910, the NorwegianAmerican Julius E. Olson of the University of Wisconsin-Madison established the Society for the Advancement of Scandinavian Study (SASS) to promote the study of Scandinavian language, culture, and history. The following year the American-Scandinavian Foundation (ASF) was founded to promote educational exchange between the United States and Scandinavia. ${ }^{43}$

Scholars often regard the period from 1890-1914 as the "heyday" of Swedish America. The period saw a high degree of organization and strong institutions developed in this time. A strong ethnic leadership emerged and articulated a Swedish-American identity, carving out a

\footnotetext{
${ }^{41}$ Johan A. Enander in Barton, A Folk Divided, 116.

${ }^{42}$ Barton, A Folk Divided, 217.

${ }^{43}$ Dag Blanck, "Scholars across the Seas: The American-Scandinavian Foundation and the Sweden America Foundation in the Trans-Atlantic Exchange of Knowledge," American Studies in Scandinavia 40, no. 1-2 (2008): 112.
} 
place for themselves in the history of America while also maintaining transnational ties to Sweden.

\section{Swedish Americans During WWI, 1914-17}

At the outbreak of the First World War on July 28, 1914, many Swedish Americans held pro-German sentiments due to Sweden's historical relationships with the belligerent powers.

While Sweden declared its neutrality in the first days of August, it had a historically antagonistic relationship with Russia, having fought numerous wars for control of the Baltic Sea and Finland. Sture Lindmark writes how a fear of Russia was instilled in many Swedes before emigration through general public attitudes and their education. ${ }^{44}$ In contrast, Sweden had a strong cultural affinity with Germany, the foremost example being that Sweden's Lutheran religion originated in Germany. Many Swedish-American newspapers came out in support of the Central Powers at the beginning of the war, with Germany being a stronghold against Russian westward expansion. ${ }^{45}$ Some papers supported Britain due to Germany's aggressive militarism, and others argued for a true American neutrality favoring neither side. Despite the differences in opinion, Lindmark argues that most Swedish-American papers agreed that the United States should remain neutral in the conflict, either to prevent the United States from aiding the Allies against Germany or because of the immoral nature of war profiteering. ${ }^{46}$

As Wilson issued ultimatums to the German government regarding their submarine warfare, asserting American neutral rights and freedom of the seas, Swedish-American papers pressed more firmly for neutrality. With the German declaration of unrestricted submarine warfare in February 1917, war seemed inevitable. When America finally declared war on the

\footnotetext{
${ }^{44}$ Lindmark, Swedish America, 72.

${ }^{45}$ Lindmark, Swedish America, 71.

${ }^{46}$ Lindmark, Swedish America, 73-4.
} 
Germans on April 7, Swedish Americans ceased their open critique of the government and affirmed their loyalty to the United States. ${ }^{47}$

The American declaration of war brought with it the nationalistic ideology of "100 per cent Americanism," demanding an undivided loyalty to American ideals and its democratic institutions through aggressive patriotic activity. Proponents of one hundred percent Americanism saw the ethnic ties of immigrants as a sign of divided loyalty, which could lead to a subversion of the war effort at home through foreign propaganda, espionage, and sabotage. Immigrants therefore must only speak English, naturalize, and support the war effort in any way they could - be it through the purchasing of Liberty or Thrift Loans, participating in Red Cross work, or attending patriotic rallies. As stated by Øverland, America’s entrance into the war came with the "requirement that immigrants forget their past, their language, and their culture and become 100 percent American."48

The movement saw activity at all levels of society. Several federal agencies pursued different routes to promote Americanization, such as the Bureau of Education, the National Americanization Committee, the Council of National Defense, and the Bureau of Naturalization. At the local level, schools, churches, and trade unions took initiative of their own to promote Americanization, and patriotic organizations cropped up across the nation. Aggressive grassroots Americanization sometimes turned to mob violence, especially against German Americans whose loyalty to the Kaiser was brought into question. In the most extreme cases, mobs forced German Americans to kiss American flags, tarred-and-feathered them, and lynched them. ${ }^{49}$

\footnotetext{
${ }^{47}$ Lindmark, Swedish America, 77-8.

48 Øverland, Immigrant Minds, American Identities, 45.

49 John Higham, Ethnic Leadership in America (Baltimore: John Hopkins University Press, 1978), 209.
} 
In this context of a popular and aggressive Americanization movement, Swedish Americans were in a precarious situation. Before the war, Swedish Americans were largely regarded as a group of well-assimilated members of America's "old stock" due to their early frontier settlement and success in urban life, coupled with new waves of immigration from southern and eastern Europe and emerging racial science. ${ }^{50}$ Their accepted status was quickly brought into question in the new war with Germany. Their group had been openly pro-German and anti-war before American entry. Their Lutheran faith suggested that Swedes might be loyal to Germany as the home of Martin Luther. Lastly, Sweden remained neutral, which left some questioning how Swedish Americans would react if their old homeland joined the Central Powers. This question became increasingly important as the actions of the conservative Swedish government - led by prime minster Hjalmar Hammarskjöld until March 1917 then Arvid Lindman until September 1917-conveyed pro-German sentiments. In one particular scandal known as the Luxburg Affair, the Swedish legation in Buenos Aries sent a coded message from the German chargé d'affaires Karl von Luxberg to Berlin via Stockholm which suggested destroying neutral Argentinian vessels. ${ }^{51}$

In response to the hostility towards ethnic affiliations, some Swedish Americans limited their use of the Swedish language in public and stopped attending the meetings of ethnic organizations, societies, and clubs. Some business owners removed "Swedish-American" from

\footnotetext{
${ }^{50}$ The pseudo-anthropological and Social Darwinist racial hierarchy placed Nordics at the top, followed by Alpines, Latins, Slavs, Asians, and Africans. Nordic peoples, such as the Anglo-Saxons, Germans, and Scandinavians were argued to have been more democratic and progressive, and their proven success in all walks of American life was evidence of their superiority. The Protestantism of Scandinavians and Germans was also more appealing to AngloAmerican sensibilities. See Erika K. Jackson, Scandinavians in Chicago: The Origins of White Privilege in Modern America (Urbana: University of Illinois Press, 2019).

${ }^{51}$ Patrick Salmon, Scandinavia and the Great Powers, 1890-1940 (New York, N.Y., Cambridge University Press, 1997), 121-2; Lindmark, Swedish America, 101-2. Salmon states that the Americans published the Luxberg telegrams during the September 1917 Swedish general elections with the intention of discrediting their Conservative government as unneutral and pro-German. This strategy proved effective, as the coalition of Liberals and Social Democrats gained control of parliament following the election. See Salmon, Scandinavia and the Great Power, 145.
} 
their signage. Others were eager to prove their loyalty through enthusiastic participation in patriotic rallies and Liberty Loan campaigns. ${ }^{52}$

While some Swedish Americans succumbed to the demands of the one hundred percent American campaign to avoid any questioning of their loyalty, members of the ethnic leadership came to the defense of Swedish-American ethnicity. They argued that despite the fears of a divided loyalty, there was no conflict of interest between their group's cultural and political loyalties. Making arguments along similar lines of those of cultural pluralists and engaging heroes and stories of their homemaking mythology, Swedish American leaders argued that their ethnic group had made significant contributions and sacrifices to the building of America, therefore, to question their loyalty was absurd.

\section{Conclusion}

In January 1918, George Creel hired Edwin Björkman to conduct Americanizing work among Swedish Americans. Björkman's work was firmly rooted within the larger historical context of Swedish immigration - its organizational and institutional networks, its homemaking mythology, its leading cultural figures and professional class, the relationship between Swedish Americans and the homeland, and the pro-Germanism of Swedish Americans present until American entry into the war. Before delving into Björkman's efforts, it is necessary to understand the work of the CPI more broadly.

\footnotetext{
${ }^{52}$ Carl Chrislock explains a similar impact on Norwegian Americans. See Carl Henry Chrislock, Ethnicity Challenged: The Upper Midwest Norwegian-American Experience in World War I, Topical Studies 3 (Northfield, MN: Norwegian-American Historical Association, 1981), 61.
} 


\section{CHAPTER III: OVERVIEW OF THE COMMITTEE ON PUBLIC INFORMATION}

On April 13, 1917, one week after the United States entered the Great War, President Woodrow Wilson created the Committee on Public Information via executive order. The CPI emerged from an expressed need to supply the American public with accurate information from federal offices, to galvanize support for the war effort, and to fill the masses with a missionary zeal in their dedication to American ideals. President Wilson appointed the muckraking journalist and devout Wilsonian George Edward Creel to serve as the civilian chairman of the Committee alongside Secretaries of State, War, and the Navy. Wilson and Creel created the Committee on Public Information, or the Creel Committee as it came to be known, as an alternative to wholesale censorship. The CPI advised newspaper editors in voluntary censorship to prevent the publishing of sensitive war information, and in return supplied editors with official information, statistics, and news stories. Although complying with the Committee's program was voluntary in theory, the Espionage and Trading with the Enemy Acts of 1917, as well as the Sedition Act of 1918, gave a legal precedent for complying with the Committee's regulations. ${ }^{53}$ Editors also knew that Creel had the ear of the President, sat on the Censorship Board, had connections within the Department of Justice, Military and Naval Intelligence, and the Post Office, and therefore conformity felt less than voluntary. ${ }^{54}$ Through this close monitoring of American media, the CPI effectively gained a media monopoly.

In addition to news censorship, an objective of the Committee was the homogenization of American public opinion centered around American nationalism and Wilsonian Mission-

Exceptionalism. Americans from across the nation, regardless of culture or creed, were to rally in

\footnotetext{
${ }^{53}$ Vaughn, Holding Fast the Inner Lines, 215-16.

${ }^{54}$ Mock and Larson, Words That Won the War, 20.
} 


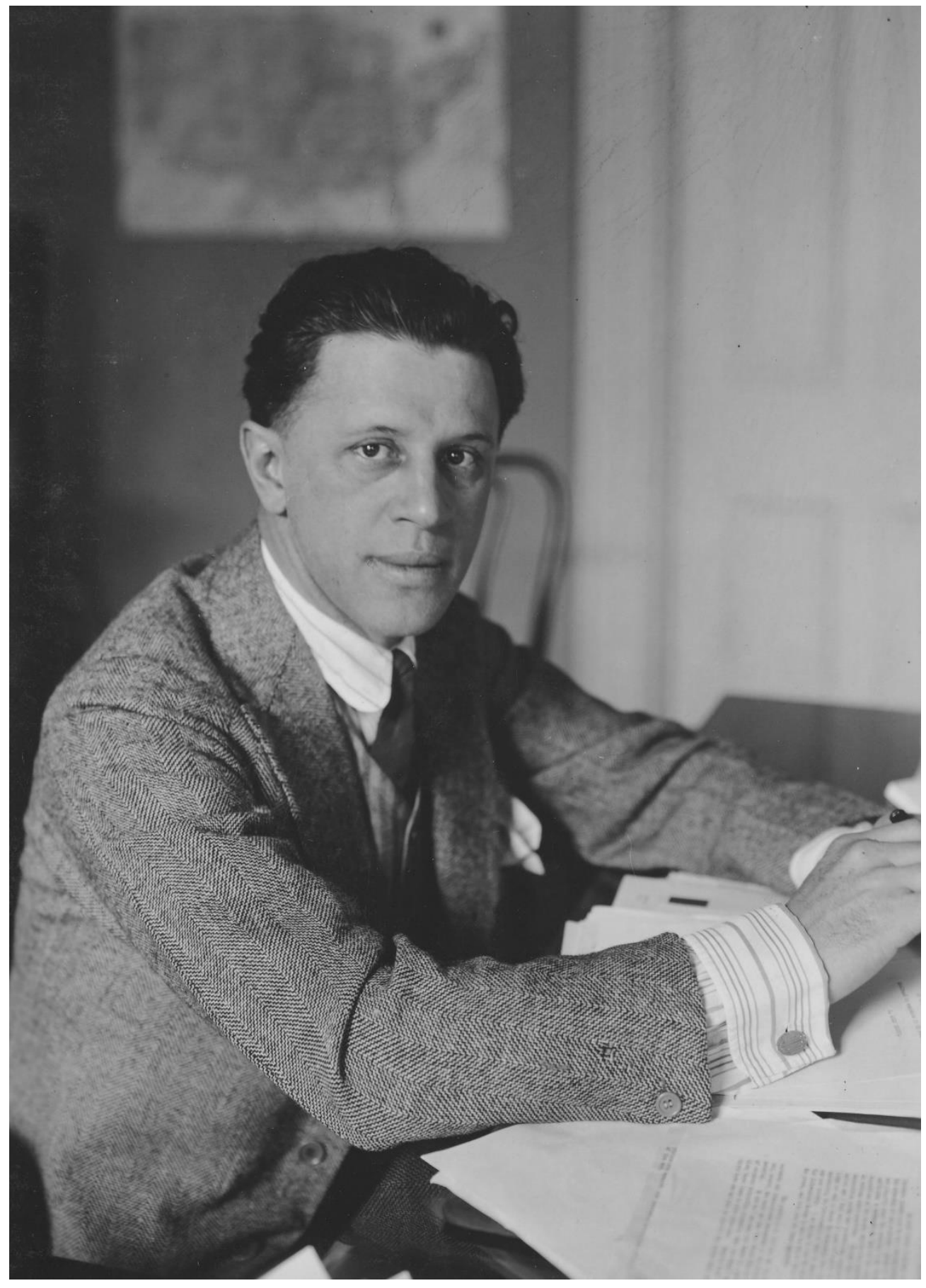

Figure 2: George Creel. Signal Corps, Photograph No. 111-SC-184, "George Creel, Chairman of the Committee on Public Information,” Photographs of American Military Activities, ca. 1918-ca. 1981, RG 111, NACP 
full support behind the ideals of freedom and individual liberty embodied in America's democratic institutions. Arthur S. Link argued that President Wilson believed deeply in American Mission-Exceptionalism, the idea that America was unique politically by organizing a diverse population into a successful democratic system, socially through its emphasis on equality over a class or caste system, and morally through its ideals of freedom, welfare, righteousness, justice, and hope. Furthermore, Wilson believed that America's success was due to God's providence, and that it was America's mission to spread freedom and democracy across the globe.$^{55}$ Wilson's peace program—articulated in his Fourteen Points—embodied this ideology, advocating for an end to the unstable system of European power politics, a system of collective security, and national self-determination.

The CPI, composed of Progressives and Wilsonians, utilized every possible means to inspire American nationalism and spread Wilson's message. Stephen A. Vaughn shows how the CPI was a magnet for Progressive intellectuals, journalists, socialists, and reformers who believed with a crusading spirit that Americanism could serve as a secular religion to unify the nation, improve society, promote morality, and strengthen democracy. ${ }^{56}$ Having a strong faith in democracy, the CPI put the education of the masses at the center. Their logic was that if they presented the facts before the public, they would naturally see the righteousness of the American cause and the evils of Prussian autocracy, feel compelled to embrace American ideals, participate in the democratic system, and support the war effort. At this time, "propaganda" lacked much of the negative connotations it gained after its use by twentieth century authoritarian regimes. Creel

\footnotetext{
55 Arthur S. Link, Woodrow Wilson: Revolution, War, and Peace (Arlington Heights: Harlan Davidson, Inc, 1979), 6. ${ }^{56}$ Vaughn, Holding Fast the Inner Lines, 23-4, 37-8.
} 
never intended to mislead the public; he merely wanted to provide them with the facts to would allow them to rationally arrive at the proper conclusions on their own. ${ }^{57}$

The result of Creel's vision for an idealistically homogenous United States was the creation of numerous divisions within the CPI to engage every segment of American society. The Division of News published the Official Bulletin, the first governmental daily newspaper, and supplied newspapers across the nation with breaking news stories; the Division of Pictorial Publicity furnished storefronts with photographs; the Division of Films supplied theaters with moving pictures; the Division of Education provided schools and libraries with books and periodicals; the Division of the Four-Minute Men filled public spaces with speakers; and other divisions and bureaus produced advertisements, cartoons, posters, and pamphlets to engage every possible demographic from workers, women, and farmers to African Americans and immigrants, all with a more or less unified message. The CPI under Creel was constantly improvising and adapting, with the opening of new offices and hiring of new personnel throughout its brief existence, eventually extending beyond the borders of the United States. ${ }^{58}$

As stated by Mock and Larson, Creel's vision for the CPI was "to make President Wilson's theories known to every village crossroads in [America] and in remote corners of foreign lands. ${ }^{\prime 59}$ The Committee established its Foreign Section consisting of three branchesthe Wireless-Cable Service, Foreign Press Bureau, and Foreign Film Division—-to supply its agents abroad with American propaganda material. Successive directors Arthur Woods, William Henry Irwin, Edgar Grant Sisson, and H. N. Rickey exported the CPI's message through fourteen

\footnotetext{
${ }^{57}$ Vaughn, Holding Fast the Inner Lines, 149. To Creel's dismay, in some instances the CPI's work turned into blatant attempts to manipulate public opinion by exploiting people's fears and creating a hatred of the enemy through atrocity propaganda. See Vaughn's example of Charles Dana Gibson in the Division of Advertising, in Vaughn, Holding Fast the Inner Lines, 149-158.

${ }^{58}$ Mock and Larson, Words That Won the War, 65.

${ }^{59}$ Mock and Larson, Words That Won the War, 49.
} 
foreign-language bureaus in countries across North and South America, Europe, and Asia. The objective of the Foreign Section varied from country to country. CPI agents abroad hoped to boost the morale of America's allies, demoralize its enemies, and sway the opinion of neutrals.

Many nations simply lacked information about the United States and others were subjected to intentionally misleading or false information through German propaganda. Creel explains how "[f]or years Germany had been building a vast publicity machine, designed to convince foreign peoples of her military power and her overwhelming pre-eminence in industry, commerce, science, and the arts. By 1917 it operated in every corner of the earth. ${ }^{\circ 0}$ The Germans emphasized their own military and industrial strength to reinforce the idea of an inevitable German victory. Upon the United States' entrance into the war, German agents had filled neutral newspapers with the idea that "by no possibility could the United States raise or train an army, and if by some miracle this did happen, the army could not be transported. America was a fat, loblolly nation, lacking courage, equipment, ships, etc." ${ }^{61}$ The CPI intended to correct such misrepresentations by stating that the United States was militarily and industrially powerful and would stop at nothing to crush Germany. Furthermore, America's goals were wholly selfless, seeking not to increase its power or territory but to "make the world safe for democracy," create a system of collective security through the League of Nations, and support national self-determination.

In addition to misrepresentations of America's strength and war aims, foreign nations also lacked more general information about life in America. Before the war, there existed few means of sending news across the Atlantic. American news that did make it to Europe, Creel stated, "dealt almost entirely with the violent and unusual in our national life: strikes, graft

${ }^{60}$ George Creel, Rebel at Large: Recollections of Fifty Crowded Years (New York: G.P. Putnam's Sons, 1947), 166.

${ }^{61}$ Creel, Rebel at Large, 167. 
scandals, sensational divorce suits, murders and riots, lynchings, and the bizarre extravagances of the newly rich and addlepated heirs to huge fortunes." ${ }^{62}$ Additionally, Creel wrote how the United States was "looked upon as a Nation of dollar-mad materialists. All the American news in foreign papers confirmed that view of us." 63 Such stories were pushed by German agents to create an image of American society that Creel intended to correct through a comprehensive educational propaganda campaign: "It was not enough to give the world daily news and daily answers to German lies. There were misconceptions of long standing that had to be met and defeated. What the other countries needed were descriptions of our development as a nation and a people; our social and industrial progress; our schools, our labor unions, and our labor laws; everything, in fact, that had bearing on the American way of life." ${ }^{64}$ The public diplomatic work of the CPI served to endear foreign populations to America's people, cities, nature, industry, entertainment, art and showcase the United States as a progressive, democratic, and powerful nation.

To lead the CPI's ambitious efforts to shape public opinion both at home and abroad, George Creel required skilled and loyal individuals, capable of effectively conveying the government's message to their target demographic. For the work among immigrants and foreign nations, an individual with intimate knowledge of the language, culture, and history of the group was preferred but not always obtained. ${ }^{65}$ In the case of the work with Swedish Americans, however, Creel was approached by the perfect man for the job, Edwin Björkman.

\footnotetext{
${ }^{62}$ Creel, Rebel at Large, 168-9.

${ }^{63}$ Creel, Rebel at Large, 168-9.

${ }^{64}$ Creel, Rebel at Large, 168-9.

${ }^{65}$ In several of the CPI's foreign offices, their representatives had scant knowledge of the language, culture, and histories of the nations in which they operated, sometimes to the detriment of the CPI's efforts. See: Gregg Wolper, "The Origins of Public Diplomacy: Woodrow Wilson, George Creel, and the Committee on Public Information" (PhD diss., University of Chicago, 1991).
} 


\section{CHAPTER IV: BACKGROUND ON EDWIN BJÖRKMAN}

As stated by CPI historians James R. Mock and Cedric Larson, Edwin Björkman was "the great driving force" behind the Committee on Public Information's Scandinavian Bureau. ${ }^{66}$ With Björkman as the primary architect of the Bureau, it is important to examine his background to understand his approach to his Americanization and propaganda work. This chapter will first examine Björkman's experience as a Swedish immigrant, his philosophical and political leanings, his literary career, his time serving the British government in Scandinavia in the first years of the Great War, his understanding of Scandinavia in the war, and his employment at the CPI. Through such an analysis of his background, it is clear that Björkman was a Swedish American, a modernist, a Progressive socialist, someone who wanted Scandinavian culture to be appreciated by the anglophone world, and one who saw the Swedish upper class clinging to their positions of power and privilege against the forces of democracy. These aspects of Björkman's identity, philosophy, and character informed his transnational worldview, which made him feel particularly qualified to serve the United States in the CPI in order to inspire the patriotism of his fellow Swedish-Americans and to facilitate a closer relationship between Sweden and the United States.

Edwin August Björkman was born on October 19, 1866 in Stockholm, Sweden to Anders August Björkman and Johanna Elizabeth Anderson Björkman. He attended South-End Higher Latin School in Stockholm. As a young man Björkman was involved in cultural affairs in Sweden, working as an actor and journalist while developing a passion for modern Swedish literature, particularly that of August Strindberg. ${ }^{67} \mathrm{He}$ also worked as a clerk, founding the

\footnotetext{
${ }^{66}$ Mock and Larson, Words That Won the War, 226.

67 "Biographical Information," in Finding Aid, 3070, Edwin Björkman Papers, Southern Historical Collection, The Wilson Library, University of North Carolina at Chapel Hill.
} 


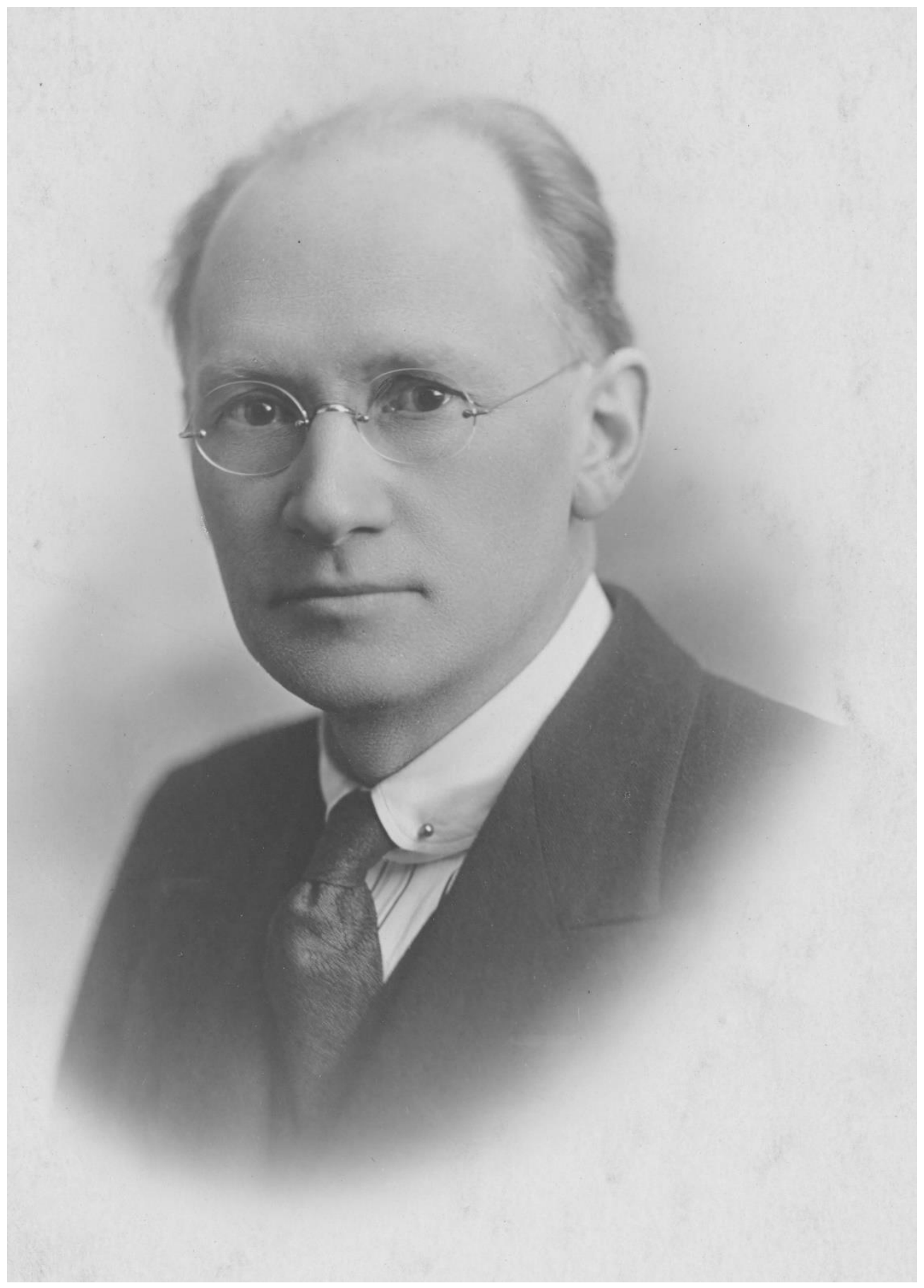

Figure 3: Edwin Björkman, July 1918. Photograph No. 165-WW-134A-3, "Edwin Björkman, Director, Scandinavian Bureau, Committee on Public Information,” July 1918, Committee on Public Information - Personnel, American Unofficial Collection of World War I Photographs, 1917-1918. RG 165, NACP. 
Swedish Wholesale Clerks' Association, which John Maxwell Hamilton identified as demonstrating Björkman's early “aptitude for organization."

Björkman's autobiographical novel, Gates of Life, published in 1923, detailed the years of his life leading up to his emigration to the United States. ${ }^{69}$ The main character, Keith Wellander, who represented Björkman, expressed sentiments similar to those of many Swedes before emigration: a desire to escape a rigid social structure and a want for greater economic opportunity. He also showed how knowledge of Swedish America, America letters, and migratory links influenced his decision to emigrate. In the novel, Keith received letters from relatives who had immigrated to the United States and "urged Keith to come to the great land of opportunity, where they were all doing very well" and where "he could surely do better than in Sweden." ${ }^{70}$ Furthermore, Björkman wrote how Keith knew he had employment opportunities among the Swedish-American press and theater, as well as romantic opportunities among the plentiful and beautiful American women. ${ }^{71}$ Keith caught the "American fever," and quickly began learning English and saving money to purchase a ticket for a steamer across the Atlantic. ${ }^{72}$ Björkman concluded his novel writing how Keith "was merely on the way...to the land of work, of youth, of the future... and perhaps it might also bring him a little real love...." ${ }^{, 73}$ The autobiographical Gates of Life reveals Björkman's emigration experience as similar to that of many other Swedes who chose to leave their homeland for greater opportunity among their countrymen in America. It shows Björkman's personal awareness of the transnational

\footnotetext{
${ }^{68}$ John Maxwell Hamilton, Manipulating the Masses: Woodrow Wilson and the Birth of American Propaganda (Baton Rouge: Louisiana State University Press, 2020), 221.

69 "Biographical Information," Edwin Björkman Papers.

${ }^{70}$ Edwin Björkman, Gates of Life (New York: Alfred A. Knopf, 1923), 148-9.

${ }^{71}$ Björkman, Gates of Life, 329.

${ }^{72}$ Björkman, Gates of Life, 150.

${ }^{73}$ Björkman, Gates of Life, 383.
} 
significance of America letters for circulating the myth of America in Sweden and highlighting the cultural vibrance of Swedish America.

Björkman arrived in New York City in 1891, then traveled to Chicago, the capital of Swedish America, where he worked for a Swedish language newspaper. The following year he moved to another Scandinavian hub in Minneapolis, Minnesota where he edited the Swedish paper Minnesota Posten. It was there that Björkman married his first wife, Rosa Odquist, a young immigrant from Goteborg, Sweden, with whom he had his only child, Frances Elizabeth, one year later. Björkman continued his newspaper career in Minneapolis, becoming a reporter and music critic for the Minneapolis Times. Having branched out from the immigrant press, Björkman returned to New York, leaving his wife and daughter behind, to write for the Sun and Times. During the Spanish-American War in 1898, Björkman served in the New York Militia. In 1906, he joined the editorial staff of the New York Evening Post and served as department editor for the World's Work in 1909. ${ }^{74}$

Edwin Björkman also showed a close personal and philosophical relationship to Progressive and socialist circles in the United States. In 1906 he married his second wife, Frances Maule of Denver, Colorado, a prominent journalist and spokesperson for the women's suffragist movement. Together they joined the Helicon Home Colony in 1907, a utopian, socialistic community in Englewood, New Jersey founded by author Upton Sinclair, and resided there until it was destroyed by fired in March of the same year. In his 1911 publication Is There Anything New Under the Sun?, a collection of essays published in various periodicals, Björkman articulated his philosophy of human social evolution from individualism, to self-consciousness, to (human) race-consciousness, and finally to what he calls the Life Spirit. Björkman explained, "Call it socialism, mutualism, solidarism, anything you care—at heart it is going to mean just

\footnotetext{
74 “Biographical Information,” Edwin Björkman Papers.
} 
this: a voluntary surrender on the part of the individual self, whereby it will be assured of all the freedom it needs and wants within the limits of a larger self." ${ }^{75} \mathrm{He}$ outlined his philosophy with “An Evolutionist's Creed," stating "I believe that life constantly seeks its own perfection through evolutionary processes that embrace every form of being." ${ }^{, 76}$

Björkman further outlined his modernist, universalist, moderate socialist, and spiritual philosophy in a 1912 collection of aphorisms, Gleams. Among the brief statements loosely organized by theme, he identified socialism as a mass movement equated with "the future way of the [human] race" and a progression toward "the material perfection of life." 77 He condemned both "the extreme individualist" who refused to accept progress as well as "the radical socialist who does not understand that natural processes are gradual and not to be hurried by man." 78 He recognized "the key to all modern thought" as "the realization of life's fluidity and relativity."79 He looked to the future with great optimism, seeing a slow and steady march toward progress and seeing humanity as moving gradually toward a spiritual universal consciousness. The final aphorism of his text reads: "My own clearest vision of God is—the Future!" 80 With Björkman's personal philosophy of optimistic moderate socialism and modernism, it is no question that he fit in well among Wilsonian Progressives, cultural pluralists, and transnationalists of the Committee on Public Information like George Creel. In fact, after Björkman had joined the CPI, NorwegianAmerican Republican Senator of Minnesota Knute Nelson wrote with disdain how Creel "is a

\footnotetext{
${ }^{75}$ Edwin Björkman, Is There Anything New Under the Sun? (New York: Mitchell Kennerley, 1911), 30-1.

${ }^{76}$ Björkman, Is There Anything New, 119.

${ }^{77}$ Edwin Björkman, Gleams: A Fragmentary Interpretation of Man and His World (New York: Mitchell Kennerley, 1912), 29.

${ }^{78}$ Björkman, Gleams, 26.

${ }^{79}$ Björkman, Gleams, 82.

${ }^{80}$ Björkman, Gleams, 93.
} 
rank Socialist, and the man Björkman, who he had employed to cooperate with the Swedes out there [in New York], is one of the same creed." 81

In addition to a philosophical treatise, Is There Anything New Under the Sun? also contained an article lamenting the ignorance of Scandinavian literature in the anglophone world. He argued that "one of the serious problems of our civilization is how to make the literary treasures of each nation the common property of mankind." 82 He explained how the Germans had often come to discover and appreciate Swedish literature but questioned how many Americans or Englishmen had ever heard of Scandinavia's contemporary writers. ${ }^{83}$ Arguing on behalf of his native land, Björkman wrote that Scandinavia possessed modern literary figures “worthy of cosmopolitan reputation," most notably, August Strindberg. ${ }^{84}$ For this reason Björkman was interested in cultural exchange between Scandinavia and the United States. He hoped to see the modern literary treasures of Scandinavia appreciated in the English-speaking world.

Björkman rose to prominence as the translator of August Strindberg and the Norwegian Bjørnstjerne Bjørnson, publishing several volumes of their plays in English from 1912-16. Furthermore, in 1912, Björkman was given the editorship of the Modern Drama Series, a collection of modern European dramas translated for American audiences. Books published in this series included plays by Norwegians Henrik Ibsen and Bjørnson. Björkman himself translated works by the Danish Hjalmar Bergstrom. ${ }^{85}$ After rising to prominence as a translator and editor of Scandinavian dramas, Björkman gained further opportunity to spread Scandinavian

\footnotetext{
${ }^{81}$ Knute Nelson to Nicolay Andreas Grevstad, March 14, 1918, 1-2, P 553, Box 2, Folder 3, Nicolay Andreas Grevstad Papers, Norwegian American Historical Association Archives, Northfield, Minnesota. Nelson feared that the CPI would assist the Non-Partisan League in the Upper Midwest in the 1918 senatorial election.

${ }^{82}$ Björkman, Is There Anything New, 201.

${ }^{83}$ Björkman, Is There Anything New, 203.

${ }^{84}$ Björkman, Is There Anything New, 201; Edwin Björkman, Voices of To-Morrow: Critical Studies of the New Spirit in Literature (New York: Mitchell Kennerley, 1913), 72.

85 "Biographical Information," Edwin Björkman Papers.
} 
literary culture in the United States when he received a fellowship by the AmericanScandinavian Foundation (ASF) in 1914. From July to December 1914, Björkman travelled to Christiania (Oslo), Stockholm, and Copenhagen "to collect materials for a history of modern Scandinavian literature." $\$ 86$

It was right as Björkman arrived in Scandinavia for his literary studies that the First World War broke out in Europe. While visiting the Scandinavian capitals, Björkman made his own assessments of the social and political situations of each nation, the moods and sympathies of their governments and public, speaking with officials and commoners alike. According to Hamilton, Björkman passed a piece of intelligence onto Wellington House while in Sweden and was then placed in charge of British propaganda there, serving as an employee of the British Department of Information from 1915-17. Hamilton states that Björkman "was ostensibly a correspondent with Reuters and the London Daily Telegraph," writing articles for British and American newspapers on the position of Scandinavia in the war while also passing information onto British intelligence. ${ }^{87}$ Björkman was regarded as one of the leading experts on Scandinavia's position in the war, and his various publications outline his understanding of their society, culture, politics, and relationship to the great powers. This view directly informed the direction of his later propaganda work for the American Committee on Public Information.

In his 1914 "Scandinavia and the War" and subsequent articles, Björkman assessed Scandinavia's internal political and social environments as well as its geopolitical relationships to the great powers. He began his 1914 pamphlet by pointing out the important fact that despite perceptions in England and America, Sweden, Norway, and Denmark were distinct political and cultural entities; "they still think and speak and act as Swedes, Norwegians, or Danes, and not

\footnotetext{
${ }^{86}$ The American-Scandinavian Foundation, Third Annual Report, 1914 (New York, American-Scandinavian Foundation, 1915), 6.

${ }^{87}$ Hamilton, Manipulating the Masses, 221.
} 
primarily as Scandinavians.." ${ }^{\$ 8}$ This being said, their geographical, historical, and cultural closeness as well as their small sizes and weak militaries encouraged cooperation between them, as seen in their joint declaration of neutrality in early August 1914. Beginning with Denmark, Björkman stated that the nation had a historically antagonistic relationship with Germany, having fought several wars over control of the southern border region of Schleswig-Holstein. While Denmark remained culturally and economically tied to Germany, they were increasingly drawn into English orbit and maintained a friendly relationship with Russia. From this, Björkman concluded, that the Danes were generally sympathetic towards the Allies. ${ }^{89}$

Norway's geographical position separated them from both Germany and Russia and oriented their maritime trade westward toward Britain. Björkman stated that the Norwegians' greatest fear was being dragged into the war through the belligerence of Denmark or Sweden, in which case Norway would be put in a position to join them. ${ }^{90} \mathrm{He}$ concluded however that given their strong maritime trade relationship with England, "their sympathies are beyond all doubt with the Allies. And with England Norway has probably more in common than with any other non-Scandinavian nation." ${ }^{\prime 1}$

For Björkman, Sweden appeared to be the largest threat to Scandinavian neutrality. From a historical and geopolitical standpoint, Björkman explained Sweden's fear of Russia, with whom they had fought numerous wars for control of Finland and the Baltic region. In the Napoleonic Wars, Sweden had lost Finland to Russia, but was compensated by gaining control over Norway from Denmark. In 1905, however, Norway gained its independence, and therefore Sweden lost the last fragment of its northern empire and was left feeling vulnerable to further

\footnotetext{
${ }^{88}$ Edwin Björkman, Scandinavia and the War (London: Oxford University Press, 1914), 4.

${ }^{89}$ Björkman, Scandinavia and the War, 6.

${ }^{90}$ Björkman, Scandinavia and the War, 8ish.

${ }^{91}$ Björkman, Scandinavia and the War, 12.
} 


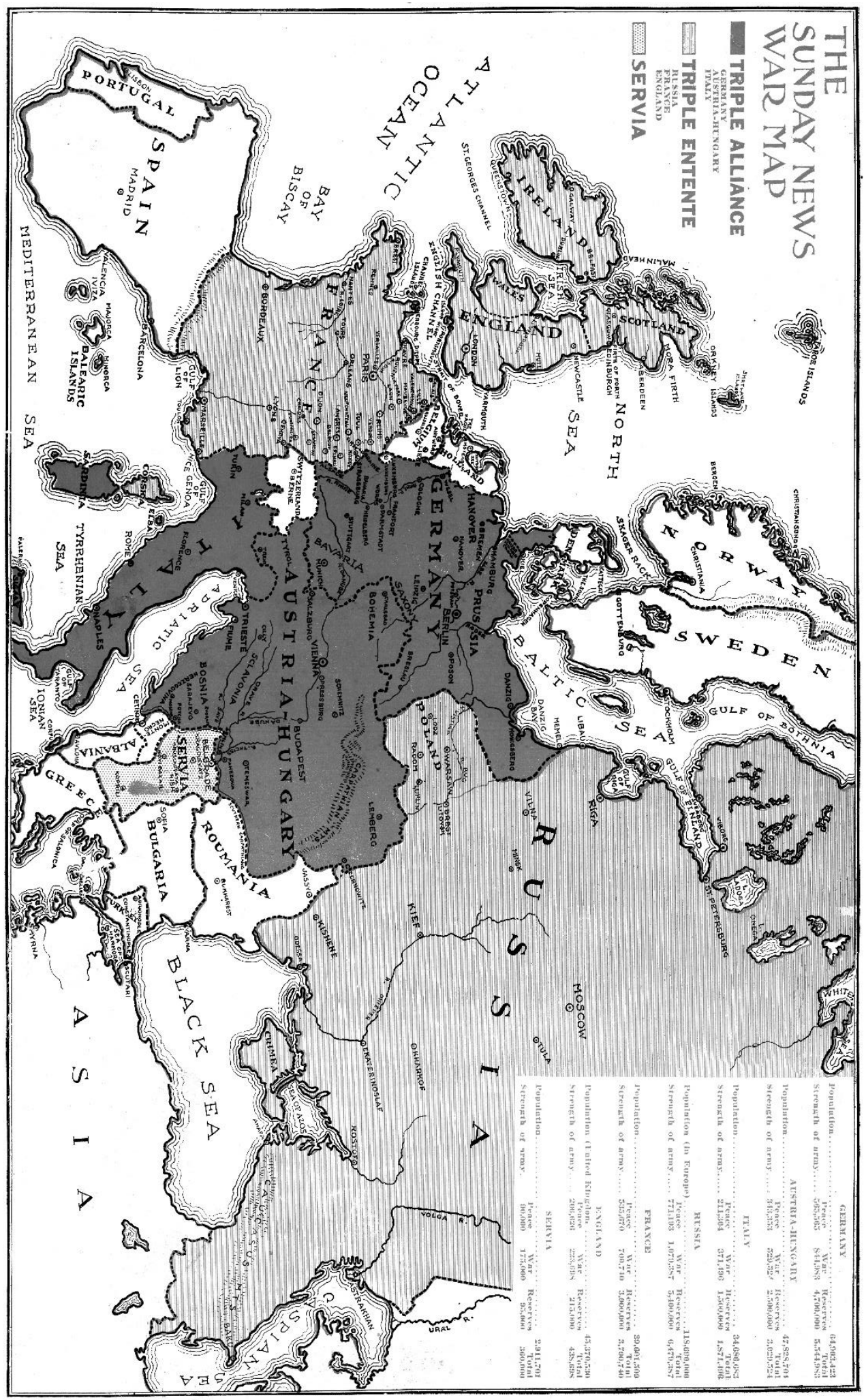

Figure 4: "The Sunday News War Map," The Sunday News, 1914. Courtesy of the David Rumsey Historical Map Collection, David Rumsey Map Center, Stanford Libraries. 
Russian incursion. With England as an ally of Russia in the war, Sweden could not trust that England would prevent westward Russian expansion. ${ }^{92}$

Moving to elements within Swedish society, Björkman explained how the Swedish upper classes were strongly pro-German. The Royal House of Sweden was close to the Hohenzollerns as King Gustav V married the German princess Victoria of Baden. In addition to the royal family, Björkman argued that the Swedish bureaucracy also held pro-German views. The absence of a democratized education system resulted in a division in Swedish society between the "gown" and "town," or the university-trained upper class and uneducated masses. ${ }^{93}$ The bureaucracy, consisting of the government, military, church, universities, businesses, and press possessed a conservative impulse to maintain their position of status, power, and privilege. In the war, the Allies appeared as the champions of modern democracy while Germany that of privilege and "bureaucratically controlled and developed state socialism." "94 Furthermore, many educated Swedes had attended German universities, Germany gave "flattering attention" to Sweden's high literary culture, and Swedish businessmen had established trade relationships with Germany. ${ }^{95}$ Lastly, up until American troops began to turn the tide of the war in France in summer 1918, Swedish leadership believed that Germany was going to win the war. With this in mind, they feared the possible repercussions of not acquiescing the Germans on their path to victory. ${ }^{96}$ For these reasons, Björkman argued, the Swedish royal and upper classes supported Germany. In stark contrast to the conservatism and pro-Germanism of the Swedish upper classes, Björkman asserted that the Swedish public strongly disliked Germany; "Sweden is not pro-

\footnotetext{
92 Björkman, Scandinavia and the War, 17.

93 Björkman, "What is the Matter With Sweden?," in Everybody's Magazine 68, no. 4 (April 1918): 45. Björkman argues that Swedish society was not divided between rich and poor but by the educated and uneducated.

94 Björkman, "Sweden's Position in the War," 217.

95 Edwin Björkman, “Sweden's Position in the War," in Scribner's Magazine, vol. 63, ed., Edward Livermore Burlingame, et. al. (New York City: Charles Scribner's Sons, 1918), 215.

${ }^{96}$ Björkman, "What is the Matter With Sweden?," 94; Björkman, "Sweden's Position in the War," 217-18.
} 
German as a nation. The bulk of the population are, if anything, anti-German. ${ }^{97} \mathrm{He}$ argued that immigration to America played an important role in the dissemination of democratic ideals in Sweden: "an uninterrupted stream of American democratic ideas and ideals has passed back to the old home, whereby now they have taken such firm hold on the people that continued existence under prevailing conditions has been rendered well-nigh unendurable. ${ }^{998}$ Additionally, he stated that the tradition of Swedish liberalism stemmed from the English and French, and that the Swedish people recognized "the English-speaking countries as the main strongholds of modern democracy." 99 This anti-Germanism was reflected in the rise of the Swedish Social Democrats in the Swedish parliament. In the face of wartime food shortages, Hjalmar Branting, leader of the Social Democrats, demanded rationing and a settlement with the Allies for the importation of foodstuffs, something which the pro-German Conservative parliament refused. The scarcity of food caused mass riots, demanding a change in government policy. The popular mood in Sweden was reflected in the Swedish general elections of September 1917, which saw the coalition of Liberals and Social Democrats gain a majority in both houses of parliament, being the first time in Swedish history where the Socialist party was represented in the ministry. ${ }^{100}$ The result was a change in Swedish policy from one of acquiescence of Germany, to what Björkman deemed one of "genuine neutrality."101 This change of official government policy did not, however, solve the issues of pro-Germanism within Swedish society.

A major problem Björkman identified which contributed to both real and perceived proGerman attitudes among Swedes was the existing system of global communications and information. In "Sweden's Position in the War," Björkman wrote how international telegram and

\footnotetext{
${ }^{97}$ Björkman, "What is the Matter With Sweden?," 45.

${ }^{98}$ Björkman, "Sweden's Position in the War," 216.

${ }^{99}$ Björkman, "Sweden's Position in the War," 216.

${ }^{100}$ Björkman, "Sweden's Position in the War," 218.

${ }^{101}$ Björkman, "Sweden's Position in the War," 218.
} 
cable news agencies - the British Reuters, the French Havas, the American Associated Press, and the Wolff Telegraphic Bureau - divided the world. All international news entering Scandinavia originated from the Wolff Bureau in Berlin; "this meant that Berlin could and did direct what Sweden should or should not receive in the way of news. It meant that a process of selection amounting to a censorship. It meant finally that the Swedish press could be fed automatically with anything which the German Government wished to spread abroad." 102 Furthermore, German businessmen purchased some Swedish newspapers and bought space in others, giving them more direct influence. It can also not be forgotten that many Swedish newspapermen in the cities were of the university-trained, conservative, pro-German bureaucracy. The result was that during the war, Sweden was largely isolated from the rest of the West, allowing Germany to push propaganda that misrepresented Allied war aims, exploited Swedish fears of Russia, and told of the inevitability of a German victory. Björkman thus concluded that the position of Sweden reflected in the press was heavily biased in favor of Germany and did not reflect the sentiments of the Swedish people.

This misrepresentation of Swedish public opinion in the press had significant implications for Swedish-American public opinion. Swedish-American newspapers received Swedish newspapers via mail in order to provide information about Swedish opinion and policy for their immigrant readers who were still interested in the popular mood and conditions in the Old Country. This information, Björkman believed, was biased in favor of Germany at nearly every level before it reached the United States. Once the papers made it to America, SwedishAmerican newspaper editors may have possessed pro-German attitudes themselves, held over from general opinion and education in Sweden before immigration. ${ }^{103}$ Even those who did not

\footnotetext{
102 Björkman, "Sweden's Position in the War," 216.

${ }^{103}$ Lindmark, Swedish America, 72.
} 
have pro-German attitudes would end up passing biased information onto their readers. This readership, maintaining a personal and emotional relationship to their homeland, would have their perception of the war influenced by this press material. Given this system of international news, Björkman believed that Swedish-American public opinion was influenced by misrepresentation of Swedish public opinion by German and pro-German actors. Having witnessed the popular democratic and pro-Allied sentiments among the Swedish masses himself while travelling in Scandinavia, Björkman believed that the major error in Swedish-American perception of Sweden needed to be exposed and corrected.

In December 1917, Björkman wrote to George Creel, chairman of the Committee on Public Information, to offer his expertise to organize patriotic activity among Swedish Americans. ${ }^{104}$ On January 15, 1918 Creel placed Björkman on the CPI's payroll and met with him to discuss the details of the CPI's new Swedish-American organization. His objective was to promote an undivided political loyalty to the United States, stimulate intense patriotic activity in support of the American war effort, and encourage exchange between the United States during and after the war. ${ }^{105}$ After discussing their plans, Creel sent Björkman to Chicago to meet with the prominent Swedish-American and former Chief Justice of the Municipal Courts of Chicago Harry Olson, who also volunteered his services to Creel, then "to Minneapolis, and to any other points that your judgement will suggest as wise."106 Creel wrote Björkman that "I have a very deep appreciation of the sacrifice that you are making [o]n behalf of the National Service, and I

\footnotetext{
${ }^{104}$ Lindmark, Swedish America, 111.

105 This is a modified list of Björkman's objectives from Lindmark, Swedish America, 111.

106 George Creel to Edwin Björkman, January 16, 1918, 1.1., 3070, folder 18, Edwin Björkman Papers, 1855-1954, Southern Historical Collection, The Wilson Library, University of North Carolina at Chapel Hill.
} 
would not have insisted upon it had I not deemed you possessed of certain abilities and knowledge that are absolutely necessary to us at this time."107

${ }^{107}$ George Creel to Edwin Björkman, January 16, 1918, 1.1., 3070, folder 18, Edwin Björkman Papers. 


\section{CHAPTER V: THE CPI AND AMERICANIZATION}

In order to understand what Edwin Björkman was trying to accomplish in his work among America's Swedish population, it is necessary to examine what Americanization meant to the Committee on Public Information. Historians of the CPI such as James R. Mock, Cedrick Larson, and Stephen A. Vaughn briefly discuss the Committee's work with America's foreign born populations, but they only touch the surface of this important aspect of their work. These historians explain that the CPI sought to educate immigrants, get them to naturalize and learn English, to facilitate their integration into American society, and to rouse patriotic loyalty to the United States. They mention how the CPI accomplished these tasks through patriotic organizations, field work, the publishing of pamphlets, and working with the immigrant press. These historians, however, do not contextualize the Committee's work among immigrants in Progressivism and the nuances of Americanization. The writings of the Committee's chairman George Creel and the head of the Division of Work with the Foreign Born, Josephine A. Roche shed light on their Progressive approach toward liberal Americanization, seeking not a wholesale assimilation of immigrants into the dominant Anglo-American culture, but rather cultural pluralism, which draws a distinction between an immigrant's ethnicity and nationality. A political allegiance to the United States and its democratic institutions was not mutually exclusive from the retention of an immigrant's ethnic identity. This particular view of Americanization was shared by Björkman, apparent from his speeches as well as the structure and practices of both the John Ericsson League of Patriotic Service and the Scandinavian Bureau.

Liberal Americanization grew out of American Progressivism. The Progressive Era, 1896-1916, emerged from a response to American industrialization, urbanization, and 
immigration. Those attracted to Progressivism were generally intensely moral members of the Protestant, Anglo-American middle class who feared for the future of American democracy in the face of political corruption, the growth of big business, and slums in the cities. Their typical occupations included journalists, educators, social workers, intellectuals, and other educated professionals. ${ }^{108}$ Progressives supported labor unions, women's suffrage, and cleaning up cities from poverty, alcoholism, and prostitution. They also encouraged Americans to take a more active role in politics to create a democratic system that truly represented the people. The election of Woodrow Wilson reflected the salience of Progressive ideals in the United States. ${ }^{109}$ The Committee on Public Information, with its missions to inspire civic engagement and spread Wilson's ideals across the globe, attracted many Progressives within its ranks. ${ }^{110}$

Immigration posed a key problem for Progressives. Around the turn of the century, the United States experienced waves of "new" immigration, primarily from southern and eastern Europe. These populations' cultural practices were perceived as alien to America's traditionally Northern European population — being largely Catholic or Jewish and coming from less industrialized, democratic, and educated nations. General American perceptions at the time held that waves of "new" immigrants concentrated in urban slums where they lived in poor, impoverished conditions that led them to lives of crime and moral indecency. Furthermore, they were isolated in ethnic districts where they retained their Old World languages and customs. This affected Progressive sensibilities, who wanted to see the slums cleaned up of crime, immorality, and corruption, with the immigrants integrated into American society.

During this time, different solutions to the immigration problem emerged. Congressmen proposed both immigration quotas and literacy tests to limit immigration from less desirable

\footnotetext{
${ }^{108}$ Rossini, Woodrow Wilson and the American Myth in Italy, 58.

${ }^{109}$ Rossini, Woodrow Wilson and the American Myth in Italy, 15-6.

${ }^{110}$ For a discussion of the Progressivism of CPI employees, see Vaughn, Holding Fast the Inner Lines.
} 
countries, however neither were implemented before the First World War. ${ }^{111}$ There were also conversations about how exactly to assimilate immigrants into American society, or to "Americanize" them. This posed the question of to what degree the immigrant should assimilate, resting on the distinction between nationality (political identity) and ethnicity (cultural identity), and if the assimilation of only the former or both were necessary for proper Americanization.

One strain of Progressive thought devised a unique solution to this question—what John Higham dubs "Liberal Americanization," what would later develop into cultural pluralism. Stemming from the humanitarian impulse of liberal Progressives in the early 1890s, those concerned with social welfare such as social workers, clergy members, and educators, went into the slums to aid immigrants as they adjusted to life in America. Rather than view the immigrants as the source of poverty, immorality, and corruption in the cities, liberal Progressives were sympathetic to the plight of the immigrant and their difficulties adjusting to life in a new country. The immigrants experienced language barriers, poor living and working conditions, con men and employers who sought to exploit them, and a general ignorance of how things worked in America. The liberal Progressives saw and inability of the immigrant to assimilate into American society rather than an unwillingness to do so. This inability to Americanize was a product of neglect and an indifference towards immigrants by the nation at large as well as the exploitation of their labor and ignorance.

For these reasons, Progressive social workers went into the slums to help educate immigrants. They taught classes in English, printed pamphlets in the immigrants' native languages, and published articles in immigrant newspapers informing them about naturalization,

\footnotetext{
${ }^{111}$ For a discussion of nativist efforts to restrict immigration before the First World War, see Robert F. Zeidel, Immigrants, Progressives, and Exclusion Politics: The Dillingham Commission, 1900-1927 (DeKalb: Northern Illinois University Press, 2004).
} 
taxes, public health, and employment. ${ }^{12}$ This work served to better the lives and conditions of immigrants, to direct them away from exploitative situations, and to educate them on the basics of American life, all of which served the intention of successfully integrating them into American society.

With the beginning of the war and the growth of the one hundred percent American movement, Higham states that liberal Progressives focused less on reforming the immigrant's environment and more on the national integration of immigrants. They pushed back against one hundred percent Americanism by stressing American cosmopolitan traditions, arguing that immigrant groups made important cultural contributions to the building of the United States and that their continued contributions further strengthened and enriched the nation. John Dewey, one of the key articulators of cultural pluralism, argued for "a unity created by drawing out and composing into a harmonious whole the best, the most characteristic, which each contributing race and people has to offer." ${ }^{113}$ Higham argues that this position of liberal Americanizers led them to rally behind Wilson's international interventionism and greater participation in the world community. Because the United States had managed to organize diverse peoples within stable democratic institutions, Wilson believed that the United States could serve as a model for a federated world. ${ }^{114}$ Informed by this notion of American Mission-Exceptionalism, Higham dubs these liberal Progressives as "national internationalists," wanting to bring Americanism to nations across the world. ${ }^{115}$ The Committee on Public Information was rooted within this

\footnotetext{
${ }^{112}$ Higham, Ethnic Leadership in America, 236, 238-40.

${ }^{113}$ Higham, Ethnic Leadership in America, 251.

${ }^{114}$ Higham, Ethnic Leadership in America, 252; Link, Woodrow Wilson, 6.

${ }^{115}$ Higham, Ethnic Leadership in America, 252.
} 
tradition of Progressive liberal Americanizers as it was George Creel's explicit goal to "bring the Gospel of Americanism" to the world. ${ }^{116}$

George Creel created the CPI's Division of Work with the Foreign Born, headed by Josephine Roche, in May 1918. While Edwin Björkman's work with the CPI to organize Swedish Americans began in January, his office was placed under Roche's Division upon its creation, whereupon it officially became the Scandinavian Bureau. The Scandinavian Bureau was one of fourteen bureaus organized under the Division of Work with the Foreign Born. ${ }^{117}$ Though Björkman worked independently of the Division, the writings of Creel and Roche provide insight into the CPI's general philosophy and conduct in working with America's immigrant populations, both of which are shared by Björkman. It is apparent from their writings that CPI leadership were Progressives who held a liberal view of Americanization, holding a humanitarian view of their work among immigrants through educating and uplifting immigrants, and promoting mutual understanding between "native" Americans and immigrants in order to promote cultural pluralism.

The CPI's Division of Work with the Foreign Born was a Progressive reaction to the numerous chauvinistic and nativist patriotic organizations that cropped up across the nation. Creel explains in his memoir Rebel at Large how various unofficial patriotic "leagues" and “societies" emerged organically, organized by patriotic citizens. In their quest to encourage support for the war effort, they often turned to emotionalism, trying "to create an effect by noise, attack, and hysteria" by exploiting public fears of spies and intrigue, of which immigrants were

\footnotetext{
${ }^{116}$ See the title of George Creel's work on the CPI: George Creel, How We Advertised America; The First Telling of the Amazing Story of the Committee on Public Information that Carried the Gospel of Americanism to Every Corner of the Globe (New York and London: Harper \& Brothers, 1920).

${ }^{117}$ The fourteen groups listed in The Creel Report include: Italian, Hungarian, Lithuanian, Russian, Jugoslav, Czechoslovak, Polish, German, Ukrainian, Danish, Swedish, Norwegian, Finnish, Dutch. See: United States Committee on Public Information and George Creel, The Creel Report: Complete Report of the Chairman of the Committee on Public Information, 1917: 1918: 1919, Civil Liberties in American History (New York: Da Capo Press, 1972), 80.
} 
often the victim. ${ }^{118}$ Such groups demanded banning the use of foreign languages despite the fact that "there were thousands of foreigners who could neither speak nor read any language but their own." ${ }^{119}$ In more direct attacks against immigrants, Creel described a "technique [that] consisted of a group descent on homes in foreign quarters and bawled demands that the inmates learn English overnight, cancel subscriptions to foreign-language newspapers, and make the Constitution and the Declaration of Independence instant studies for their children." ${ }^{120}$ Such actions, Creel believed, only pushed immigrants "further into aloofness," causing them greater fear and anxiety and ultimately undermining all attempts at integrating them into American society. ${ }^{121}$ Despite trying to accommodate such spontaneous organizations, Creel stated that the groups complained that the CPI refused "to preach a gospel of hate." ${ }^{122}$ Creel's negative descriptions of popular Americanization campaigns during the war places the work of the CPI among the foreign born in stark contrast.

Josephine Roche's work among America's immigrants fell within the humanitarian tradition of Progressivism. Creel placed the blame for the immigrant's inability to integrate into American society on the failure of American institutions to facilitate the process. John Maxwell Hamilton states that Creel believed that newcomers "needed education, protection from con men, public employment bureaus, and health clinics. ${ }^{123}$ Roche shared Creel's sentiment, as she stated in her final report for the Division of Work with the Foreign Born that the intention of the Division was to "meet and conquer the bitternesses bred by years of neglect and even injustice" experienced by immigrants in America. ${ }^{124}$ She boldly stated elsewhere that "the numerous un-

\footnotetext{
${ }^{118}$ Creel, Rebel at Large, 195-96.

${ }^{119}$ Creel, Rebel at Large, 197.

${ }^{120}$ Creel, Rebel at Large, 198.

${ }^{121}$ Creel, Rebel at Large, 197.

${ }^{122}$ Creel, Rebel at Large, 196.

${ }^{123}$ Hamilton, Manipulating the Masses, 218.

${ }^{124}$ United States Committee on Public Information and Creel, The Creel Report, 80.
} 
American conditions and injustices to which so many immigrants have fallen victim must be wiped out." 125 The division sent volunteers into immigrant homes to clear up confusion about draft regulations, tax provisions, and other laws. ${ }^{126}$ They also provided immigrants with printed and verbal information through pamphlets, the immigrant press, and public speakers on naturalization, health care, child rearing, and vocational training. ${ }^{127}$ The purpose was-just as the humanitarian progressives of the 1890 s - to aid the immigrant through education and opportunity. The sooner an immigrant became safe and secure in their new American environment, the sooner Creel and Roche believed they would be able to integrate into American society, embrace its ideals, and support its wartime mission.

The conduct of the Division of Work with the Foreign Born's work also reflected its support of cultural pluralism. In Relentless Reformer, a biography of Josephine Roche, Robyn Muncy argues that Roche believed that immigrants were a "source of enrichment and renewal for the United States." 128 Roche wrote how "mutual sympathy and understanding [would] eventually weld into one the many units composing our national destiny." ${ }^{129}$ Muncy states how Roche "envisioned 'active participation in a common purpose and life by the native born and foreign born together,' not the disappearance of immigrant values or practices into an already existing and dominant American culture." 130 Furthermore, it was through the immigrant's native language and through their ethnic institutions that they came to be integrated into the larger American society. ${ }^{131}$

\footnotetext{
125 Muncy, Relentless Reformer, 98.

${ }^{126}$ Creel, Rebel at Large, 195.

${ }^{127}$ Muncy, Relentless Reformer, 100.

${ }^{128}$ Muncy, Relentless Reformer, 101.

129 Josephine A. Roche in Muncy, Relentless Reformer, 101.

${ }^{130}$ Roche in Muncy, Relentless Reformer, 101.

${ }^{131}$ Muncy and Roche, Relentless Reformer, 101.
} 
When forming an individual ethnic bureau within the Division of Work with the Foreign Born, she engaged the existing leadership and organizations within those groups. ${ }^{132}$ She wrote in her final report, "cooperation and suggestions of their leaders and the foreign language press and organizations were sought" when selecting bureau leadership. ${ }^{133}$ Muncy states that the selection process was intended to be "thoroughly democratic," so that the Division would genuinely represent the foreign-language groups and effectively communicate the federal government's message. ${ }^{134}$ She believed that if her Division truly represented the ethnic groups and communicated with them through familiar means in a language they understood, then the CPI's work would be made all the more effective.

In a further display of Creel and Roche's belief in cultural pluralism, the purpose of the division was also to educate native-born Americans about the heritages of America's immigrant populations. Creel and Roche believed that a "mutual process of education" was the only means to truly "rectify the wrong condition affecting the foreign born." ${ }^{135}$ Creel clearly argued that:

The ignorance of many native-born Americans about European peoples and their contemptuous attitude toward persons with different customs from their own are just as serious obstacles to assimilation and unity as the tendency of some immigrants to cling to Old World ways; understanding must come, on our part, of the heritages of these newcomers, their suffering and struggles in Europe, and the contributions they bring us if we will only receive them. ${ }^{136}$

To facilitate this education of the native-born, the Division wanted the foreign-language press to supply English-language newspapers with articles about their respective ethnic communities. ${ }^{137}$

\footnotetext{
132 Creel, Rebel at Large, 195.

${ }^{133}$ United States Committee on Public Information and Creel, The Creel Report, 80-1.

${ }^{134}$ Muncy, Relentless Reformer, 99.

${ }^{135}$ Creel, How We Advertised America, 198; United States Committee on Public Information and Creel, The Creel Report, 81.

${ }^{136}$ Creel, How We Advertised America, 198.

${ }^{137}$ Muncy, Relentless Reformer, 100.
} 
Muncy argues that Roche's division was "an agency genuinely devoted to democracy and cultural diversity." 138

Lastly, it is apparent that Roche understood the transnational significance of America's immigrant population and the role her division could play in influencing public opinion abroad. Roche stated in her final report that while there was a need to rectify the injustices against America's immigrant population, "there was also the need of giving European countries an immediate and convincing realization of America's aims and ideals in the war." ${ }^{139}$ She explained how by "bringing their former countrymen, now American residents, into closer cooperation with the country's activities meant that our message would reach these people abroad from the source they most trusted." ${ }^{140}$ It is with this very mission in mind—-that of bringing America's message abroad - that led to the opening of CPI offices across the world, however it is significant that the CPI saw that this objective began with the foreign populations living in the United States who maintained transnational channels of communication with their homelands.

The heads of the Committee on Public Information and its Division of Work with the Foreign Born were Progressives who believed in a liberal form of Americanization. They reacted against the forced assimilation of immigrants by chauvinistic patriotic groups through a more sympathetic and cooperative approach. Roche and her colleagues worked with ethnic leaders and organizations to best meet the needs of immigrants, communicating with them through familiar channels and — quite literally—in a language they could understand. In their promotion of cultural pluralism, though they might not have called it by that name, they argued that foreign values and practices were not a threat to the nation, but rather a gift to America that further enriched it. This was a message which they attempted to communicate with the broader

\footnotetext{
${ }^{138}$ Muncy, Relentless Reformer, 101.

${ }^{139}$ United States Committee on Public Information and Creel, The Creel Report, 80.

${ }^{140}$ United States Committee on Public Information and Creel, The Creel Report, 80.
} 
American public. Lastly, they saw immigrants as doorways to the world, whereby winning immigrants over to American ideals could facilitate their transmission to their countrymen abroad. This overview of the CPI's philosophy of Americanization and conduct among immigrants lays the groundwork for a more in-depth understanding of Edwin Björkman's work in the John Ericsson League of Patriotic Service and the Scandinavian Bureau, as his approach follows this line closely, and having begun his work four months before the creation of the Division, it may have served as a model. 


\section{CHAPTER VI: THE JOHN ERICSSON LEAGUE OF PATRIOTIC SERVICE}

After his first meeting with George Creel in mid-January 1918, Edwin Björkman

travelled to Chicago to meet former Chief Justice of the Municipal Courts Harry Olson to discuss the creation of a CPI-backed Swedish-American patriotic organization. After a month and a half of preparation, Björkman announced the formation of the John Ericsson League of Patriotic Service (JELPS) on March 4 in Chicago. ${ }^{141}$ As stated in the League's constitution, the objectives of the League were:

a. To support the national war policy;

b. to act as a clearing house for patriotic activities among American citizens of Swedish blood;

c. To work for national unification;

d. To promote better understanding and [a] closer relationship between the peoples of the United States and Sweden. ${ }^{142}$

Historians of the CPI and Scandinavian immigration history have had little to say about the JELPS. They mention how organizing the League was Björkman's first and foremost task, with it being created "to coordinate patriotic work among Swedish Americans." ${ }^{143}$ With Björkman framed as an "Americanizer" by Sture Lindmark and H. Arnold Barton, it is implied that the League conducted this work in order to assimilate Swedish-Americans into AngloAmerican culture and society. Due to the JELPS's brief treatment in published primary and secondary sources, the full scope of its organization and purpose has largely been overlooked.

\footnotetext{
${ }^{141}$ Edwin Björkman to Arthur Woods, February 28, 1918, entry 105, box 4-5, CPI; "Men of Swedish Blood Join for Patriotic Work," Chicago Tribune, March 5, 1918, 2.

142 "Provisional Constitution of the John Ericsson League of Patriotic Service," Swenson Archives, MSS 123, Box 1, Folder 13, Jules G. U. Mauritzson Papers, Swenson Swedish Immigration Research Center Archives, Rock Island, Illinois.

${ }^{143}$ Lindmark, Swedish America, 111. Similar statements in Barton, A Folk Divided, 247; Chrislock, Ethnicity Challenged, 112; Hamilton, Manipulating the Masses, 221. It is also mentioned in published primary sources: United States Committee on Public Information and George Creel, The Creel Report, 85; Creel, How We Advertised America, 185.
} 
The JELPS's organizational structure and message showcase Björkman's approach toward liberal Americanization and cultural pluralism. The league utilized existing SwedishAmerican leadership and organizations to send a consistent message to Swedish-Americans nationwide. This message did not include the assimilation to Anglo-American culture, but one that drew a clear distinction between nationality and ethnicity—a devotion to American democratic institutions did not necessitate abandoning one's cultural heritage. By encouraging displays of American patriotism through collective action in Swedish-American organizations, the League aided in the development of a transnational Swedish-American hybrid identity. Such collective action also had other transnational implications, as it was the expressed objective of the League to influence Swedish public opinion abroad. This section will analyze the JELPS's organizational structure, Björkman's correspondence and speeches, and the League's activities to shed light on this important aspect of Björkman's work with the CPI.

\section{Organizational Structure}

Edwin Björkman and Judge Harry Olson organized the John Ericsson League to be representative of Swedish-Americans nationwide. The League was headed by an Executive Committee, consisting of a president, vice president, secretary, treasurer, and eight other members. There was then a National Council of 100 to oversee the creation of branch and district councils as well as local committees. It was the intention of Björkman and the CPI for the League to appear as a spontaneous outburst of patriotic fervor among Swedish Americans rather than something imposed upon them by the federal government, as such could garner negative perceptions in Sweden. ${ }^{144}$ Therefore, the civilian Judge Olson served as president with Edwin

\footnotetext{
${ }^{144}$ Hamilton also mentions that the JELPS was intended to "appear spontaneous." See Hamilton, Manipulating the Masses, 221.
} 
Björkman, a federal employee, serving as secretary and national organizer. Despite such appearances, the League should be understood as one facet of Björkman's work with the CPI. ${ }^{145}$

As stated in the League's constitution, members of the Executive Committee and National Council were "chosen from among the representative men and women of Swedish origin in this country," except for two positions held by the president and secretary of the American-Scandinavian Foundation. ${ }^{146}$ The constitution listed the names, occupations, and locations of the 100 members of the National Council. On it appeared prominent Swedish settlements in America such as Jamestown, NY; Worcester, MA; Chicago, Rock Island, and Moline, IL; Minneapolis and St. Peter, MN; and Seattle, WA. Among those chosen were the presidents of the Swedish-American Augustana and Gustavus Adolphus Colleges; heads of the Swedish-American Scandia Mutual Aid Society, United Swedish Societies, and Illinois Women of Swedish Origin; editors of the Swedish-American press; and current and former state and federal officials among other leading Swedish Americans. ${ }^{147}$

The JELPS's National headquarters was in Judge Olson's native Chicago at 1347 Conway Building with state councils established for Minnesota and Iowa, district councils in New York, Minneapolis, San Francisco, and local councils in several other cities and towns across the nation. ${ }^{148}$

By establishing itself in major Swedish-American population centers across the nation and securing the cooperation of renown Swedish-American leaders—-be they politicians, professionals, college presidents, or organizational leaders - the JELPS sought to become a

\footnotetext{
${ }^{145}$ It cannot be forgotten that Judge Olson wrote to Creel offering his services. See George Creel to Edwin Björkman, January 16, 1918, 1.1., Folder 18, Edwin Björkman Papers, 1855-1954, \#3070, Southern Historical Collection, The Wilson Library, University of North Carolina at Chapel Hill.

146 "Provisional Constitution," Jules G. U. Mauritzson Papers.

147 "Provisional Constitution," Jules G. U. Mauritzson Papers.

148 "John Ericsson League Rents Office in Loop," Chicago Tribune, March 13, 1918, 7; "Men of Swedish Blood Join for Patriotic Work," Chicago Tribune, March 5, 1918, 2. There is no clear description of every district, branch, and local council and the distinctions between them are rather vague.
} 
patriotic league truly representative of the United States' Swedish-American population. As a result, the League was better positioned to meet the unique needs of the Swedish-American population in disseminating information and planning patriotic activities. Furthermore, this organizational structure affirmed Swedish-American ethnic affiliation and their transnational hybrid identity.

\section{Expansion of the League}

Edwin Björkman played a key role in encouraging Swedish Americans to form local branches of the John Ericsson League of Patriotic Service. Stated in the JELPS's constitution was their intention to "seek the cooperation and affiliation of existing religious, political, benevolent and social organizations." ${ }^{149}$ Such organizations already had established leadership, networks, membership, and renown in their communities, allowing the League to engage local populations of Swedes more effectively by supplying preexisting organizations with information and advising them on patriotic activities. With this system in mind, Björkman travelled to Swedish-American communities on the east coast and Midwest, speaking in front of large crowds of Swedish Americans, meeting with prominent Swedish-American organizations and leaders, and forming JELPS councils.

Judge Olson formally organized the League in Chicago on Monday, March 4, 1918 while Björkman began a tour across the Midwest to visit fourteen Scandinavian settlements in six days in an effort to organize local councils. To gain an understanding of how SwedishAmerican organizations across the nation fell in line with the JELPS, a few examples from Björkman's tour will be examined. Björkman arrived first in Rock Island, IL on March 7. Speaking at the Rock Island Club, he addressed professors and staff of Augustana College as well as the broader Swedish-American community of Rock Island and Moline. Björkman

149 “Provisional Constitution,” Jules G. U. Mauritzson Papers. 
establish a local JELPS council who met the following week in the college gymnasium. Among the speakers were college president Gustav Andreen (a member of the JELPS Executive Committee) and Dr. C. J. Bengston (editor of the Augustana Book Concern, the publishing house of the Augustana Synod). ${ }^{150}$

Moving quickly onto Chicago, on March 9 Björkman addressed the Swedish-American Republican League of Illinois at their annual convention, "one of the most important organizations of its kind in this country," according to Björkman. ${ }^{151}$ At this meeting, the group decided to change the name of their organization to the John Ericsson Republican League of Illinois, removing the "hyphen" while maintaining a Swedish-American ethnic connection as well as signaling their loyalty by falling in line with the JELPS. ${ }^{152}$

On March 11, Björkman spoke at the annual convention of the Swedish-American Society of Iowa in Ottumwa. Similarly to the Republican League of Illinois, the SwedishAmerican Society of Iowa proposed a name change to the John Ericsson League of Iowa. Furthermore, the organization passed two resolutions which their newly elected secretary, Eskil C. Carlson, forwarded onto George Creel. The first stated "That we approve the purposes and objects of the John Ericsson League of patriotic service and that we tender the use of our organization to carry out its aims of government service." The second longer resolution affirmed the society's loyalty to the United States and their "willingness to give and do whatever the need of our country may require in order that the victory of our cause may be achieved, to the end that

\footnotetext{
150 “John Ericsson League Meets,” Daily Times (Davenport, IA), March 15, 1918; Blanck, The Creation of an Ethnic Identity, 130.

${ }^{151}$ Edwin Björkman to Arthur Woods, February 28, 1918, entry 105, box 4-5, CPI. March 9 marked the anniversary of the Battle of Hampton Roads where Swedish-American engineer John Ericsson's ironclad warship, the Monitor, defeated the Merrimac, saving the Union fleet from destruction during the Civil War in 1862.

152 "History," in Finding Aid, John Ericsson Republican League of Illinois records, 1934-1962, Swenson Swedish Immigration Research Center Archives, Rock Island, Illinois.
} 
peace, liberty and security may be established and forever maintained by and between all the nations of the earth." 153

Björkman then visited several other Scandinavian settlements in the upper Midwest, including Minneapolis, St. Paul, St. Peter, and Mankato among others before returning to the east coast. Once back in the east, Björkman spoke at patriotic rallies in Jamestown, NY and Worcester, MA, organizing local JELPS councils in each location. Björkman was not alone in this work, however, as other rallies were held in Minneapolis by Harry A. Lund, vice president of the National Council, who went on to organize a district council including the states of Minnesota, North Dakota, and South Dakota. ${ }^{154}$

Not all Swedish-American communities welcomed Björkman and the John Ericsson League with open arms. Björkman ran into trouble when trying to arrange a patriotic rally to establish a local JELPS chapter in Sioux City, Iowa. In a letter to George Creel, Björkman explained that the resistance was based on "the plea that the Swedes there are so loyal that no meetings are needed." 155 In the eyes of the Swedes of Sioux City, holding a patriotic rally would imply that there was disloyalty among them, a charge tantamount to treason during the war. Nevertheless, Björkman held a meeting in the city and laid out a plan to establish a Sioux City chapter of the League. ${ }^{156}$

Though he encountered some resistance, Björkman facilitated the creation of local JELPS chapters. In order to achieve this, he often worked through existing Swedish-American societies, organizations, and clubs, engaging an established leadership and membership base, taking these networks and placing them under the umbrella of the JELPS. This is a further example of how

\footnotetext{
${ }^{153}$ Eskil C. Carlson to George Creel, March 16, 1918, entry 110, box 7, CPI.

154 "Lund to Head Council of Ericsson League," Star Tribune (Minneapolis, MN), March 15, $1918,10$.

${ }^{155}$ Edwin Björkman to George Creel, April 12, 1918, entry 105, box 4-5, CPI.

156 “Treason is Sneaking About," Sioux City Journal (Sioux City, IA), May 14, 1918, 7.
} 
the League affirmed Swedish-American ethnic affiliation and their transnational hybrid identity. With the formation of local councils, the League could effectively reorient Swedish-American energy and rhetoric toward intense patriotic loyalty to the United States, though not at the expense of their cultural heritage.

\section{Björkman and the League's Message: Nationality vs. Ethnicity}

When Björkman organized John Ericsson League chapters in Scandinavian settlements across the eastern and midwestern United States, he spoke before large crowds denouncing German lies, demanding undivided loyalty to the United States, and encouraged intense patriotic activity to be organized through the newly established League. It is from these speeches that Björkman's liberal conception of Americanization most strongly comes through. This view was rooted in cultural pluralism in that it made a clear distinction between nationality and ethnicity, arguing that an undivided political loyalty to the United States did not necessitate abandoning one's cultural heritage. The elements of "Swedishness" that Björkman denounced were remnants of a political loyalty to Sweden, whereas the elements of Americanization that he demanded were vital to American citizenship.

A key feature of Björkman's early rallies was the denunciation of German lies about Sweden's close relationship with Germany. As explained previously, much of the press material received from Sweden stemmed originally from the German Wolff Telegraphic Bureau, then filtered through pro-German Swedish newspaper editors before being shipped across the Atlantic to the Swedish-American press. In one speech, Björkman explained to his ScandinavianAmerican audience how "the Swedish-American press in this country has taken its news and views almost exclusively from the [pro-German] conservative press in Sweden" which has tried to influence Swedish papers in America "for the purpose of keeping the Swedes of this country 
Swedish and preventing them from becoming thoroughly Americanized." ${ }^{157}$ The object of these efforts were for the Swedish conservatives to retain their positions of privilege and to help the German war effort. Contrary to the misrepresentations of the pro-German Swedish press, Björkman revealed how "the mass of the Swedish people sympathize with the allied cause," with four-fifths of them belonging to liberal or socialist parties. ${ }^{158}$

Björkman then denounced German propaganda agents in the United States who paid "special attention" to Swedes due to "the reputed friendship of the Swedish and German aristocracies." ${ }^{159}$ In a speech used in Sioux City, IA and Worcester, MA, Björkman warned of treason, "whispering lies into any ears found open. Sometimes it speaks in German. Sometimes, I am sorry to say, in Swedish. Mostly it speaks a plain United States—but almost always with a foreign accent." 160 This voice, he warned, said "Germany is Sweden's best friend, and that when you fight Germany you fight Sweden. It's a lie.” The truth was that Germany threatened that they would let Russia "take in the North what it we must lose in the South," and when Germany wins the war, Scandinavia "will have to come in with us," meaning that Scandinavia will be absorbed into the German Empire. Invoking recent racial science, the German propagandists also said that "the Germans are the nearest kinsmen of the Swedes" and therefore are natural allies. Björkman countered with a racial argument of his own; "Stuff and nonsense! As far as blood goes, the English and the Scotch are a good deal closer to the Swedes than the Slav Prussians and the Celtic Bavarians." 161

\footnotetext{
157 “Address given by Mr. Edwin Björkman at Worcester, Mass., April 8, 1918,” 3070, folder 302, Edwin Björkman Papers, Southern Historical Collection, The Wilson Library, University of North Carolina at Chapel Hill.

${ }^{158}$ Des Moines Register (Des Moines, IA), March 13, 1918, 1; "Björkman Tells Swedes to Take Down Swedish Flag," Hartford Courant (Hartford, Connecticut), February 26, 1918, 2.

159 "Fold Up Flag of Sweden and Lay it Away," Daily Times (Davenport, IA), March 8, 1918, 22.

160 "Untitled Speech," 3070, folder 302, Edwin Björkman Papers.

161 "Untitled Speech,” Edwin Björkman Papers.
} 
In refuting these aspects of German propaganda targeted at Swedish Americans, Björkman revealed the transnational relationship they maintained with their homeland. Björkman needed to deconstruct German arguments regarding the political, ideological, and biological closeness between Sweden and Germany due to the fact that Swedish Americans were influenced by events and opinions back in Sweden. The pro-German Swedish press and conservative upper classes did not represent the Swedish people. He explained that the Swedish masses were not pro-German but supported the Allies and democracy. Therefore, to be proAmerican was to be pro-Swedish, as democratization was the true will of the Swedish people. Furthermore, he purported that Swedes were closer biologically to the peoples of Great Britain rather than Germans, providing further evidence that cooperation between them was natural.

The final "German lie" that Björkman sought to refute was one regarding the future of Swedish ethnic identity in the United States amidst calls for "100 per cent Americanism." Björkman explained how the German propagandists said, "that a new Know-nothingism [sic] will arise and threaten your Swedishness," implying that nativists will force Swedish-Americans to abandon their cultural heritage. ${ }^{162}$ Björkman stated strongly how "English must be the only official language of this country" and that everyone must know it and "know it well. But if we choose to know Swedish besides, and to use it among men of our own race, nobody cares. No one wishes to interfere with your racial customs, your songs, your newspapers, your churches. But you must see those things in their proper light and proper proportions." ${ }^{163} \mathrm{He}$ then made the key distinction in the Committee on Public Information's approach toward Americanization. "You must not confuse race and nationality, so that race is put first and you continue to be

\footnotetext{
162 "Untitled Speech," folder 302, Edwin Björkman Papers. The Know Nothing movement was a nativist political movement in the 1850s which was primarily anti-Catholic and anti-immigration.

163 "Untitled Speech," folder 302, Edwin Björkman Papers. Björkman uses the term "race" in this context as we would use "ethnicity" today.
} 
Swedes politically. If you do-well, then you'll not be wanted here." ${ }^{164}$ Björkman reiterated this sentiment in another speech:

Wherever I go I tell the men of our race not to be afraid of their Scandinavian heritage, but merely to make a distinction between race and nationality. They are Scandinavian by blood. They need not be ashamed of this fact. They need not hide it or forget it. But they must always bear in mind as clearly as possible that this fact has nothing to do with their American nationality and that this fact of nationality must stand foremost and uppermost in their lives. ${ }^{165}$

To clarify this point for his listeners, Björkman pointed to the example of the Swedish and American flags. Proponents of one hundred percent Americanism saw the Stars and Stripes as an important symbol of political loyalty to the United States, and therefore the flying of foreign flags was a statement of disloyalty. Björkman asked his audience, "Have you considered what the Swedish flag is to you now? It is a memory — that's all. Memories are sweet. Memories are useful. But he who lives only in his memories at a critical time like this is lost." ${ }^{\text {166 }}$ In a speech in Rock Island, Björkman encouraged his listeners to "furl up the Swedish flag and gently lay it aside. ${ }^{" 167}$ He explained his logic, asking:

Have you ever considered where your Swedishness lies? Does it lie in your veins and your blood, in your brains and your thoughts, in your hearts and your actions-or in something outside of yourself, like the Swedish flag, for instance? You cannot lose your Swedishness. It is an inseparable part of yourselves. It is a heritage that will pass on to your children and children's children — even if every Swedish flag in this country should be lost. ${ }^{168}$

Björkman's statements regarding the questions of Swedish-American nationality and ethnicity are clear articulations of the Committee on Public Information's liberal Americanization. Björkman argued in favor of cultural pluralism and the acceptance of a

\footnotetext{
164 “Untitled Speech,” folder 302, Edwin Björkman Papers.

165 “Address given by Mr. Edwin Björkman," folder 302, Edwin Björkman Papers.

166 "Untitled Speech,” folder 302, Edwin Björkman Papers.

167 "Fold Up Flag of Sweden and Lay it Away," Daily Times (Davenport, IA), March 8, 1918, 22.

168 "Untitled Speech,” folder 302, Edwin Björkman Papers.
} 
transnational hybrid identity — one of a mixed Swedish-American cultural identity but of an undivided American nationality. While Björkman acknowledged that Swedish-Americans maintained an emotional tie back to Sweden, he asserted that their loyalty must lie with the American nation and not their former homeland. This being said, American nationality did not conflict with a Swedish cultural identity. "Swedishness," Björkman argued, was hereditary and perpetuated through language and custom, not externalities symbolizing the Swedish state such as the flag.

Björkman's message from the JELPS then contained a call to action for his Scandinavian-American audience; "what can we as Scandinavians do in particular to help the nation?"169 Having acknowledged the reality of Swedish and Scandinavian ethnicity in the United States, Björkman encouraged a cooperation within these groups to move toward further integration into American society, with the JELPS playing a key role in this process. "We simply propose to use these natural ties to perfect the net-work [sic] of organization needed to make the nation stand as one man — and a well-armed man at that —against the common foe. In other words, we mean to use these ties to help the nation win the war." ${ }^{170}$ Going into more detail, he lays out a clear list of actions Scandinavian Americans could take to help the nation during the war:

We can see that our men and women, old and young, become American in the full sense of that word; that they become naturalized, that they learn the language of the country, that they share fully in its life as a nation. Finally we can see that the people of our race are given every support in their effort to find the most satisfactory and effective outlets for their unquestioned and unquestionable patriotism. ${ }^{171}$

\footnotetext{
169 “Address given by Mr. Edwin Björkman,” folder 302, Edwin Björkman Papers.

170 "Untitled Speech,” folder 302, Edwin Björkman Papers.

171 “Address given by Mr. Edwin Björkman," folder 302, Edwin Björkman Papers.
} 
With this patriotism came the broader support for President Wilson's war aims.

Björkman reminded his audience that the United States did not go to war to crush any nation, to oppress any people, or conquer any territory, but for:

the institution of universal peace and order; the re-organization of the world on a basis of right instead of might; the safeguarding of democracy and democratic progress throughout the habited world. ... Our victory as a nation means victory for all that we believe embodied in the word Americanism, for all that we believed symbolized in the Stars and Stripes... human freedom, human equality, human brotherhood. ${ }^{172}$

While Björkman argued that there was no contradiction between American political loyalty and Swedish cultural identity, nationality must come first. Swedish Americans must become citizens, learn English, support American ideals, and aid the war effort. It was through existing ethnic ties, however, that patriotic work in support of the war effort could be undertaken, and it was the explicit purpose of the John Ericsson League of Patriotic Service to facilitate such activity.

\section{Activities of the League}

The John Ericsson League of Patriotic Service roused patriotism, facilitated Americanization, and supported the American war effort among Swedish Americans. The League's approach to these activities shows Björkman's and the CPI's dedication to cultural pluralism and transnationalism, as they encouraged Swedish-Americans to come together as a distinct group to display their patriotism rather than doing so solely as Americans. The League worked with the Swedish-American press to distribute information; furnished speakers that appealed to Scandinavian-American audiences; established a charity, the Soldiers' and Sailors' Aid Committee, to help Swedish-American troops; and encouraged its members to use their contacts in Sweden to spread American ideals.

172 “Untitled Speech,” folder 302, Edwin Björkman Papers. 
The John Ericsson League encouraged its local councils and affiliated organizations to host patriotic rallies and meetings in their local communities to generate excitement and explain to attendees on how to contribute to their nation during the war. The League furnished local rallies with individuals of special interest to Scandinavian-American audiences. Such speakers included Ira Nelson Morris, American Minister to Sweden; Senator Irvine Lenroot of Wisconsin and Governor Joseph A. A. Burnquist of Minnesota; Norwegian polar explorer Captain Roald Amundsen; and Dr. William Henry Schofield, President of the American-Scandinavian Foundation. ${ }^{173}$ The speakers told their audiences how best to serve the nation during the war, the crimes the Germans have committed against their countrymen in Scandinavia, disparaging stories about the German Kaiser, and other such topics.

One means by which the League encouraged Swedish Americans to support the war effort was through financial contributions. The JELPS told its members to buy Liberty Bonds, war savings stamps, thrift stamps, and to support the Red Cross. ${ }^{174}$ At the League's first meeting in Minneapolis on March 4, they launched a thrift stamp campaign. ${ }^{175}$ At one meeting in Rush City, MN, JELPS vice president Harry A. Lund invoked the Swedish people's history of "intense loyalty and their spirit of sacrifice," describing how Gustavus Vasa fought for Sweden's independence from the Scandinavian Kalmar Union in 1520. Just as then, when Sweden's women gave up their jewels, pewter plates, and copper and brass kettles to support Sweden's independence, Swedish Americans should purchase thrift stamps and Liberty bonds. ${ }^{176}$ The JELPS also offered their services in the Liberty Loan Drives, which saw immigrants of all

\footnotetext{
${ }^{173}$ Edwin Björkman to George Creel, July 11, 1918, entry 105, box 4-5, CPI; "Scandinavians Plan Meetings," Daily Times (Davenport, IA), July 17, 1918, 15; "Norse of Our North Urged to Larger Loyalty," Chicago Tribune, March $12,1918,8$.

174 “John Ericsson League," Lindsborgs-Posten (Lindsborg, Kansas), May 1, 1918, 2.

175 "Getting Together," Daily Transcript (Norman, Oklahoma), March 5, 1918, 1.

176 "Lund and Robertson Talk to Swedish Folk at Rush City, Minn.," Star Tribune (Minneapolis, MN), March 31, 1918, 4.
} 


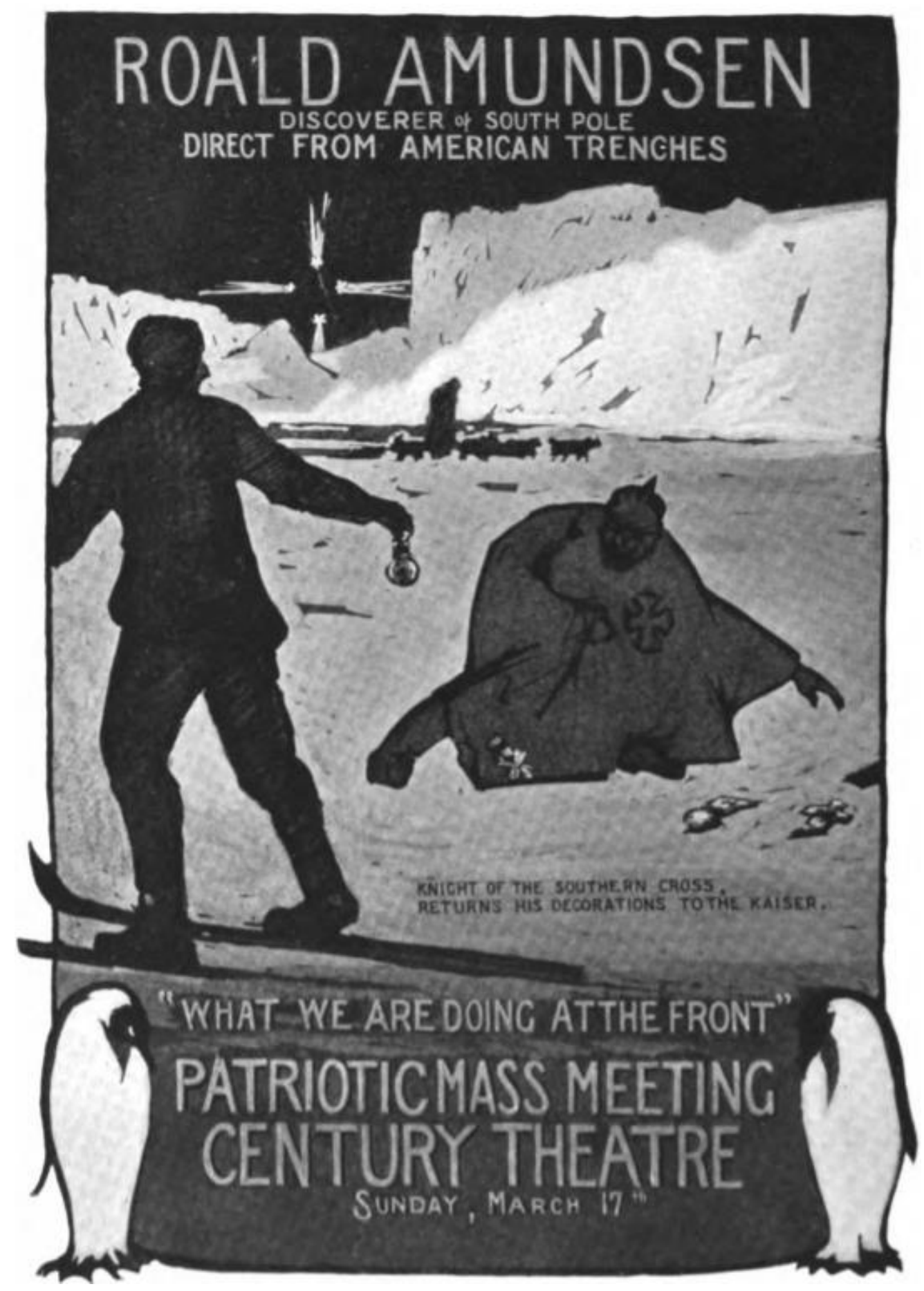

Figure 5: Jonas Lie, "Roald Amundsen, Discoverer of the South Pole, Direct from American Trenches," poster, 1918. Reproduced from The American-Scandinavian Review 6, no. 3, (May-June 1918), 150, digitized by Google. The caption states that Roald Amundsen "lectured throughout the country" as "the guest of our government." This poster, painted by Norwegian-American artist Jonas Lie, advertised a lecture at the Century Theater in New York on March 17. 
backgrounds clamoring to purchase as many as they could afford to prove their group's superior loyalty to the nation. After the Third Liberty Loan drive in April, the JELPS published a report from the Foreign Language Division of the Cook County Third Liberty Loan Committee proudly stating that the Swedes of Chicago raised $\$ 2,500,000 .{ }^{177}$

In addition to supporting nationwide fundraising efforts for the war, the John Ericsson League also established a fund of its own to support young Swedish-American men in the army and navy. In early May 1918, the League's Executive Committee established the Soldiers' and Sailors' Aid Committee with Rev. C. J. Engstrand serving as chairman. ${ }^{178}$ Anna L. Stohle supervised its headquarters in Brooklyn and was "assisted by a number of other patriotic ladies of Swedish descent, who have voluntarily offered their services." ${ }^{" 179}$ The JELPS was to form local committees to "look after every American fighter of the Swedish race in camps, naval stations and hospitals, as well as relatives visiting them." 180

To accomplish this, it was the committee's goal to raise $\$ 100,000$ to help SwedishAmerican soldiers yet to be deployed combat loneliness, "one of their worst enemies." 181 The Committee stated that "We want to see that every American fighter of Swedish blood is given every attention and comfort possible on this side of the water. We shall have representatives of the committee looking out for their welfare in every camp and cantonment up to the time they sail for the European battle fields." 182 Björkman explained further in an interview how, "Many of

\footnotetext{
177 “Nyheter från John Ericsson League,” Nordstjernan, May 24, $1918,7$.

178 “Brighten Soldiers' Lives," Brooklyn Citizen, May 3, 1918, 7.

179 “Nyheter från John Ericsson League," Nordstjernan, July 2, $1918,7$.

180 "Swedes at Front to be Cared For," Brooklyn Citizen, May 9, 1918, 3.

181 "Swedes in US to Raise \$100,000 for Boys in War," Chicago Tribune, May 3, 1918, 4; "Brighten Soldiers' Lives," Brooklyn Citizen, May 3, 1918, 7.

182 "Swedes in US to Raise \$100,000 for Boys in War," Chicago Tribune, May 3, 1918, 4.
} 
them come from the far west. They will see no friends of their acquaintance during the training period. We shall be their friends everywhere they go until they leave the country." 183

The committee led fundraising campaigns in the major Swedish-American settlements of Chicago, Seattle, New York, and Minneapolis. Björkman stated how he believed that "We shall have no trouble raising the necessary funds, for we have found the Swedish-Americans eager to help every patriotic movement since the war started. We believe this new body will be of great help to the boys that are going forth to fight for the homeland." ${ }^{184}$ Fundraising for the committee was aided by prominent Swedish-American artists. Hugo von Hofsten donated a painting of the battle between the Monitor and Merrimac to be sold "for the benefit of the committee." Charles Hallberg also gave a painting. As one article stated, "As a patriotic work, as well as from an artistic standpoint, this kind of giving should be encouraged. Art will be bound more closely to country when the proceeds of art go to the relief of America's sons."185

The John Ericsson League of Patriotic Service served as a clearinghouse for information relevant to Swedish-American audiences. This aspect of the League's work in particular reveals its close cooperation with the CPI and Björkman's Scandinavian Bureau. While Björkman attempted to maintain the appearance of a distinction between the two organizations - one newspaper even wrote how "this league has no connection with the public information department" — an article discussing the Rock Island council of the League mentioned how it would "act as a bureau of information for the people," keeping in touch with departments in Washington and distributing information to those asking for it. ${ }^{186}$ It is presumed that Björkman played a key role in this distribution of government information, as he was head of the CPI's

\footnotetext{
183 “Nyheter från John Ericsson League,” Nordstjernan, July 2, $1918,7$.

184 "Swedes in US to Raise \$100,000 for Boys in War," Chicago Tribune, May 3, 1918, 4.

185 Chicago Tribune, May 19, 1918, 47.

186 “Treason is Sneaking About," Sioux City Journal (Sioux City, IA), May 14, 1918, 7; “John Ericsson League Meets," Daily Times (Davenport, IA), March 15, 1918, 22.
} 
work among Swedish-Americans tasked directly with supplying that population with propaganda material to rouse patriotic fervor.

By encouraging intense patriotic activity among Swedish Americans and spreading the message of America's noble war aims, Björkman and the leaders of the John Ericsson League hoped that America's message would travel through the immigrants' transnational connections back to Sweden. This objective was clearly stated in the League's constitution: "To promote better understanding and [a] closer relationship between the peoples of the United States and Sweden." ${ }^{187}$ Björkman expanded on this notion in one interview, saying "Our league hopes to open channels through Swedish-Americans with their native land direct, so that public opinion in Sweden, which is now vital to the allies, may be influenced." ${ }^{188}$ Björkman believed that the League was uniquely situated to effectively push back against the pervasive German propaganda in Scandinavia that attempted to misrepresent the motives of the Allies and bring Scandinavia into Germany's sphere of influence: “it is of great importance that the allies should use every possible weapon against German propaganda in the Scandinavian peninsula. The new league is in a position to render a great service." 189

Leaders of the League explicitly mentioned a few tactics to influence public opinion in Sweden. Björkman wrote in one piece of correspondence to George Creel that he intended to "issue a much wider appeal for the writing of private letters to Sweden." 190 This tactic relied on the transatlantic relationships maintained between individuals following immigration. Much like the "America letters" that spread the "myth of America" in Sweden which compelled many to emigrate, Björkman continued to see this method as an effective means of communicating

\footnotetext{
187 “Provisional Constitution,” Jules G. U. Mauritzson Papers.

188 "Norse of Our North Urged to Larger Loyalty," Chicago Tribune, March 12, 1918, 8.

189 “Influencing Sweden," Chicago Tribune, March 14, 1918, 6.

${ }^{190}$ Edwin Björkman to George Creel, March 14, 1918, entry 105, box 4-5, CPI.
} 
American ideals in Sweden. Members of the League would have likely been patriotic citizens, who through the League, had been educated on America's war aims and its altruistic motives. This message could be communicated back to Sweden by average members of the League to their friends and relatives.

Another means by which the League influenced public opinion in Sweden was through the Swedish-American press. Just as pro-German Swedish papers made their way to the United States, Swedish-American papers also made their way back to Sweden. News stories of patriotic rallies and of mass fundraising would be shown to friends and relatives or be published in the Swedish press. The Committee on Public Information viewed such articles showing Swedes the tremendous loyalty of their countrymen to the American cause as an extremely effective form of propaganda abroad. As Josephine A. Roche, head of the CPI's Division of Work with the Foreign Born wrote in her final report, "Bringing their former countrymen, now American residents, into closer cooperation with the country's activities meant that our message would reach these people abroad from the source they most trusted." 191

\section{Conclusion}

The John Ericsson League of Patriotic Service was Edwin Björkman's first effort to rouse Swedish Americans into greater patriotic activity and reflected his and the CPI's dedication to liberal Americanization, cultural pluralism, and transnationalism. Structured to be truly representative of Swedish America, Björkman worked with Swedish American leaders, cooperated with existing Swedish-American organizations, and formed local chapters in major Swedish-American population centers. Acknowledging transnational ties to Sweden, Björkman refuted German propaganda regarding the political, ideological, and biological closeness between Sweden and Germany, arguing that to be pro-American was to be pro-Swedish. $\mathrm{He}$

${ }^{191}$ United States Committee on Public Information and Creel, The Creel Report, 80. 
promoted cultural pluralism by arguing in favor of a hybrid Swedish-American cultural identity but an undivided American nationality. The League's activities affirmed ethnic affiliations by encouraging Swedish-Americans to come together as a distinct group to display their patriotism as well as use their transnational ties in an attempt to influence public opinion in Sweden. 


\section{CHAPTER VII: THE CPI, JELPS, AND THE FOURTH OF JULY 1918}

The Fourth of July 1918 was an important day for immigrants across the United States to display their undivided loyalty to their adopted nation. Responding to a petition signed by twenty-four different ethnic groups, President Wilson dedicated the day to America's foreign born population. For the occasion, Wilson delivered an address at George Washington's tomb at Mount Vernon, accompanied by delegates of thirty-three of America's ethnic groups. The day also saw parades and mass patriotic rallies in big cities and small towns across the nation, featuring special immigrant displays showcasing their unique costumes, songs, dances, and contributions to the building of the American nation. The largest of the celebrations was in New York City, which hosted a parade consisting of around forty different nationalities, an estimated 70-110,000 marchers, and lasting for over ten hours. ${ }^{192}$

The idea for an occasion for the foreign born to show their undivided loyalty to the nation did not originate from the President's desk nor from the ethnic petitioners, but from within the Committee on Public Information. This chapter will discuss the CPI's role in the 1918 Fourth of July celebration. More specifically, it will explore Edwin Björkman's work via the Scandinavian Bureau and John Ericsson League of Patriotic Service in organizing the activities of Swedish Americans, which included a request for the cancellation of the Swedish Midsummer festival. It will then look closely at the Swedish-American section of the New York parade and the image of Swedish America the marchers conveyed to their "native" American audience. The intention of the CPI, Björkman, and the JELPS were to show Swedish Americans' undivided loyalty to the United States while also embracing cultural differences. Swedish Americans conveyed this message through ethnic dress and song, as well as displays of their unique contributions to the

192 “Day-Long Pageant Pictures American United for War,” New York Times, July 5, 1918, 1; “100,000 March in Great Pageant of Liberty Here Representing All Races," New York Herald, July 5, 1918, 7. 
building of the United States, such as their participation in the war, benevolent institutions, and floats displaying the homemaking myths of New Sweden and John Ericsson. The content of the Swedish section of the parade reflects the CPI's dedication to cultural pluralism, as well as displays the immigrant's hybrid identity. Lastly, the celebration was of transnational significance as the CPI distributed images and stories of the event among Scandinavians abroad.

\section{Background on the Celebration}

The origin of the 1918 Independence Day celebration dedicated to America's immigrants lies within the Committee on Public Information. George Creel, the committee's chairman, writes openly in How We Advertised America how the celebration was the brainchild of Will Irwin, head of the CPI's Foreign Section. "One of the great ideas of the war," he explained, was to have the celebration be "turned over" to America's foreign born to demonstrate their loyalty and devotion to the United States and its free institutions. ${ }^{193}$ In The Creel Report, the chairman stated that the celebration showed how “'Americans by choice' came here with the same hopes as did our pilgrim ancestors, and willing, as they were, to make the supreme sacrifice for their nation's safe continuance, and knowing, as they did, the cost of freedom." ${ }^{194}$ Dedicating America's Independence Day did not have a solely domestic utility, as the head of the Foreign Section likely knew. In addition to a sense of unity and enthusiasm, the celebration also influenced foreign public opinion. Creel explained, "when neutral nations saw men and women of their blood declaring a great faith in the ideals of America, our cause was bound to know a great strengthening." 195

Just as all other work among the foreign born, the CPI took steps to make the celebration appear organic, as coming from the immigrants themselves rather than from the federal

\footnotetext{
${ }^{193}$ Creel, How We Advertised America, 200.

${ }^{194}$ United States Committee on Public Information and George Creel. The Creel Report, 84.

${ }^{195}$ Creel, How We Advertised America, 200.
} 
government to prevent, in Irwin's words, "the enemy from saying that the government had bludgeoned the foreigners into taking this action." 196 In early May as the idea was floated within the CPI, Edwin Björkman twice wrote Irwin to "Advise against using names of people directly connected with [the] Committee," to avoid compromising the sincerity of the celebration in the eyes of foreign populations. ${ }^{197}$ The Committee operated through their loyalty leagues and other cooperative organizations to put together a petition signed by twenty-four different ethnic groups appealing to the President to dedicate Independence Day to the foreign born, "to manifest by special celebrations our loyalty to this country and to the cause for which we fight." 198 Among the Swedish-American signatories were Judge Harry Olson and Harry Lund, president and vice president of the John Ericsson League of Patriotic Service. The petition appeared on Wilson's desk on May 21, and "with the fire having been built under him, [he] fell into line." The CPI drafted Wilson's proclamation in response to the petition in their office, whereafter Wilson "merely added a few 'may I nots'," and was published in the CPI's Official Bulletin on May $25 .{ }^{199}$

The CPI then got to work organizing Fourth of July celebrations across the nation. Will Irwin and Josephine Roche contacted governors and mayors of various cities to issue proclamations of their own while the heads of the CPI's ethnic bureaus got to work mobilizing their networks of Leagues and organizations.

\footnotetext{
196 Will Irwin in Hamilton, Manipulating the Masses, 214.

${ }^{197}$ Edwin Björkman to Will Irwin, May 6, 1918, entry 105, box 4-5, CPI; Edwin Björkman to Will Irwin, May 7 , 1918 , entry 105 , box 4-5, CPI.

198 "Citizens of Foreign Birth Will Demonstrate Loyalty with Great Celebrations of the Nation's Birthday," Official Bulletin, May 25, 1918, 1, 7.

${ }^{199}$ Will Irwin in Hamilton, Manipulating the Masses, 214.
} 


\section{Björkman Cancels Midsummer}

As Swedish Americans began planning mass displays of patriotism for the Fourth of July, they were also planning for a celebration nine days prior-Swedish Midsummer. Edwin Björkman, ever-eager for Swedish Americans to cement their undivided loyalty to the United States, foresaw the summer festival as potentially undermining his goal. Midsummer was a celebration held on the feast day of St. John the Baptist on June 24 adapted from the preChristian celebration of the summer solstice, where Swedes don their folk costumes, sing songs, and dance around a maypole, a tradition which Swedish immigrants maintained in the United States. Despite the perceived innocence of such "jollification," Björkman sensed a potential problem with the traditional Swedish holiday. In a letter to Will Irwin, Björkman explained how Sweden had no national day like the Fourth of July and in recent years attempts had been made to make Midsummer such an occasion. Swedish-American elements within the United States have made "strenuous attempts" to make the holiday "a means of expressing and emphasizing the Swedishness" of Swedish Americans. The seasonal festival had turned into "a political demonstration, the unspoken thought of which has been to keep the Swedes from becoming too thoroughly Americanized."200

As explained in previous sections, Björkman had no qualms about Swedish Americans maintaining their cultural traditions in the United States so long as their political loyalty lay with America; he was not offended by their folk costumes, songs, and maypole but by the implication that Swedish Americans remained loyal to Sweden's political institutions. In some cases, organizers of Midsummer celebrations took steps to limit Swedish political symbolism by leaving out the Swedish flag and "references to Swedish affairs," and instead using the day to “express their patriotic feelings as Americans." Despite these actions, Björkman concluded that it

${ }^{200}$ Edwin Björkman to Will Irwin, June 4, 1918, entry 105, box 4-5, CPI. 
would be best to curtail Midsummer celebrations as much as possible and have all efforts focused on the Fourth of July. ${ }^{201}$ Björkman issued statements throughout the Swedish-American press stating, "President Wilson, having designated Independence Day for special celebration by [the] foreign born in recognition of their splendid loyalty, I venture an appeal to all Americans of Swedish race that patriotic demonstrations planned for Midsummer day be postponed until July fourth." 202

In his letter to Irwin, Björkman mentioned the work being done across the nation by the John Ericsson League of Patriotic Service to cancel Midsummer celebrations and cement their Independence Day plans. Judge Harry Olson organized a meeting of 800 leading SwedishAmericans in Chicago to work out their Independence Day program. Heads of the Moline, IL; Minneapolis, MN; and Des Moines, IA local JELPS councils informed Björkman that they cancelled their Midsummer festivals and provided their updated plans for the Fourth. Some cities held Midsummer celebrations however, such as in Duluth, MN, where Gustav Hadman, Secretary of the Swedish-American League, wrote Björkman that expensive arrangements had already been made, but he assured Björkman that the festival would be "All American" with net proceeds going to the Red Cross. ${ }^{203}$

\section{The New York Parade}

The largest and most impressive Fourth of July celebration was the parade in New York City. ${ }^{204}$ The parade, organized by the Mayor's Committee on National Defense, consisted of two sections. The first contained the armed forces of the United States and Allies as well as civilians

\footnotetext{
${ }^{201}$ Edwin Björkman to Will Irwin, June 4, 1918, entry 105, box 4-5, CPI.

202 "Fosterländska Festligheter," Lindsborgs-Posten (Lindsborg, Kansas), May 29, 1918, 1; “An Appeal to Americans of Swedish Birth," Oregon posten, May 29, 1918, 5.

${ }^{203}$ Edwin Björkman to Will Irwin, June 4, 1918, entry 105, box 4-5, CPI.

204 The New York parade was just one of numerous similar celebrations held in cities and towns across the nation. Other large Scandinavian festivities occurred in Chicago and Minneapolis, having parades and mass meetings afterwards in local parks, with many smaller events in other cities and towns. See Björkman's "Report on Scandinavian Fourth of July Celebrations," July 18, 1918, entry 105, box 4-5, CPI.
} 
directly involved in the war effort, such as workers in munitions factories and shipyards, and members of the Red Cross, Young Men's Christian Association (YMCA), Salvation Army, the CPI's Four Minute Men, and teachers. ${ }^{205}$ The second section contained representatives of around forty different ethnic groups living in the United States. In a clear articulation of Orm Øverland's homemaking myths, the New York Times wrote how "each foreign nationality proudly display[ed] its own contribution to America's national life, or its own work in the ancient struggle for the ideals which have become regarded as America's own," with each having "some claim to a part in the upbuilding of America or some display of its achievements in the struggle to establish liberty, justice, and democracy.",206

Estimates of the numbers of marchers ranged anywhere from 70-110,000 individuals, with some 123 floats and 150 marching bands. ${ }^{207}$ A Censorship Committee "supervised the character of the floats and the inscriptions on the banners" to ensure a wholly patriotic message for the primarily "native" American audience, lining the streets along the parade route from Washington Square down Fifth Avenue to 72 nd Street. ${ }^{208}$ Prizes were issued for the best floats, pageantry, and arrangements of units, as well as diplomas of merit and honorable mentions.

\footnotetext{
205 "Day-Long Pageant Pictures American United for War," New York Times, July 5, 1918, 1.

206 "Day-Long Pageant Pictures American United for War," New York Times, July 5, 1918, 1.

207 "Day-Long Pageant Pictures American United for War," New York Times, July 5, 1918, 1; "110,000 to March in Today's Great Patriotic Parade," New York Times, July 4, 1918, 1; “109,415 I paraden den 4 juli,” Nordstjernan, July 30, 1918, 12. Groups included a Zoroastrian, Armenians, Albanians, Assyrians, Belgians, Chinese, Bolivians, Bulgarians, Czecho-Slovaks, Bohemians, Carpatho-Russians, Cubans, Venezuelans, Swiss, Portuguese, Japanese, Syrians, the British and their colonies (including Scotland, Canada, New Zealand, East India, South Africa), Danes, Finns, Swedes, Norwegians, French, Germans, Greeks, Hungarians, Italians, Irish, Jews, Lithuanians, Polish, Russians, Ukrainian Cossacks, and Haitians. See "100,000 March in Great Pageant of Liberty Here Representing All Races," New York Herald, July 5, 1918, 7.

208 “110,000 to March in Today’s Great Patriotic Parade," New York Times, July 4, 1918, 1. The only controversy regarding a parade display pertained to that of the Hungarians. The Italian section took issue with floats depicting Hungary's national heroes, military achievements, and national costumes due to the fact that the United States was at war with Austria-Hungary. The Hungarians were willing to abandon their floats but not their national costumes, as every other ethnic group was able to wear theirs. Ultimately, the Hungarians had to scrap their costumes as well, marching in plain clothes with banners of Hungarian-American mutual aid, literary, and political societies.
} 
The Brooklyn John Ericsson League of Patriotic Service organized the Swedish section of the parade, working with other local Swedish-American organizations to find volunteers and raise funds for their floats. ${ }^{209}$ In Björkman's “Report on Scandinavian Fourth of July Celebrations," he noted that the John Ericsson League worked "in close co-operation [sic] with the Scandinavian Bureau" and "were instrumental in preparing the celebrations among people" of Swedish origin. ${ }^{210}$ The result of the joint effort by the CPI and League's work was an impressive display of both Swedish heritage and Swedish contributions to the building of the United States.

The Swedish section was led by two men dressed as soldiers of the early eighteenth century Swedish King Carl XII carrying a banner reading "Sweden," followed by the members of the Swedish organizing committee and ministers of various Swedish-American churches. Behind them was a men's choir singing Swedish songs such as "Stå stark, du ljusets riddarvakt" ("Stand Strong, You Guardian of the Light”) and "Sångarfanan" (“The Singers' Banner"). The paper Nordstjernan wrote how "The audience probably liked the Swedish songs, for the applause tolled tremendously in strength each time the songs ended." ${ }^{211}$ Following the choir were various Swedish American associations holding their respective banners and service flags as well as American flags. In a display of Sweden's' colonial heritage, they had a float depicting the settlers of New Sweden. Nordstjernan described the float as such:

\footnotetext{
209 "Fjärde Juli paraden," Nordstjernan, June 25, 1918, 12.

${ }^{210}$ Edwin Björkman, "Report on Scandinavian Fourth of July Celebrations," July 18, 1918, entry 105, box 4-5, CPI.

211 “Svenska afdelingen I den väldiga fjärde Juli-paradaen,” Nordstjernan, July 9, 1918, 12.
} 


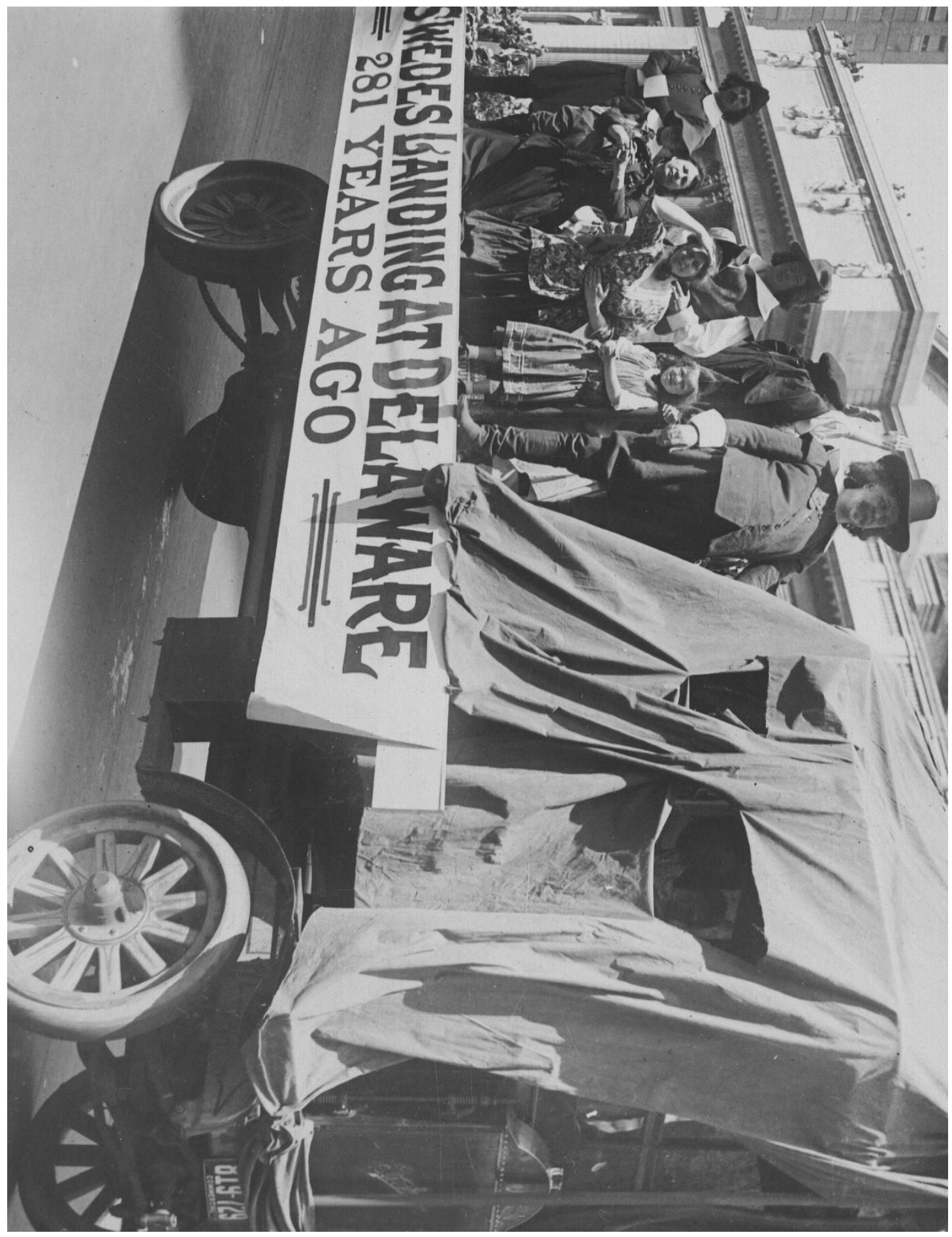

Figure 6: The Swedish-American float depicting the colonists of New Sweden in the New York parade, July 4, 1918. Und. \& Und., 165-WW-72D-8, "July 4th Parade on Fifth Avenue, New York City. Swedish float in the parade. More than forty-two nations were represented in parade," July 4, 1918, Ceremonies Independence Day, 1918, 1917-1918, American Unofficial Collection of World War I Photographs, 19171918, RG 165, NACP. 


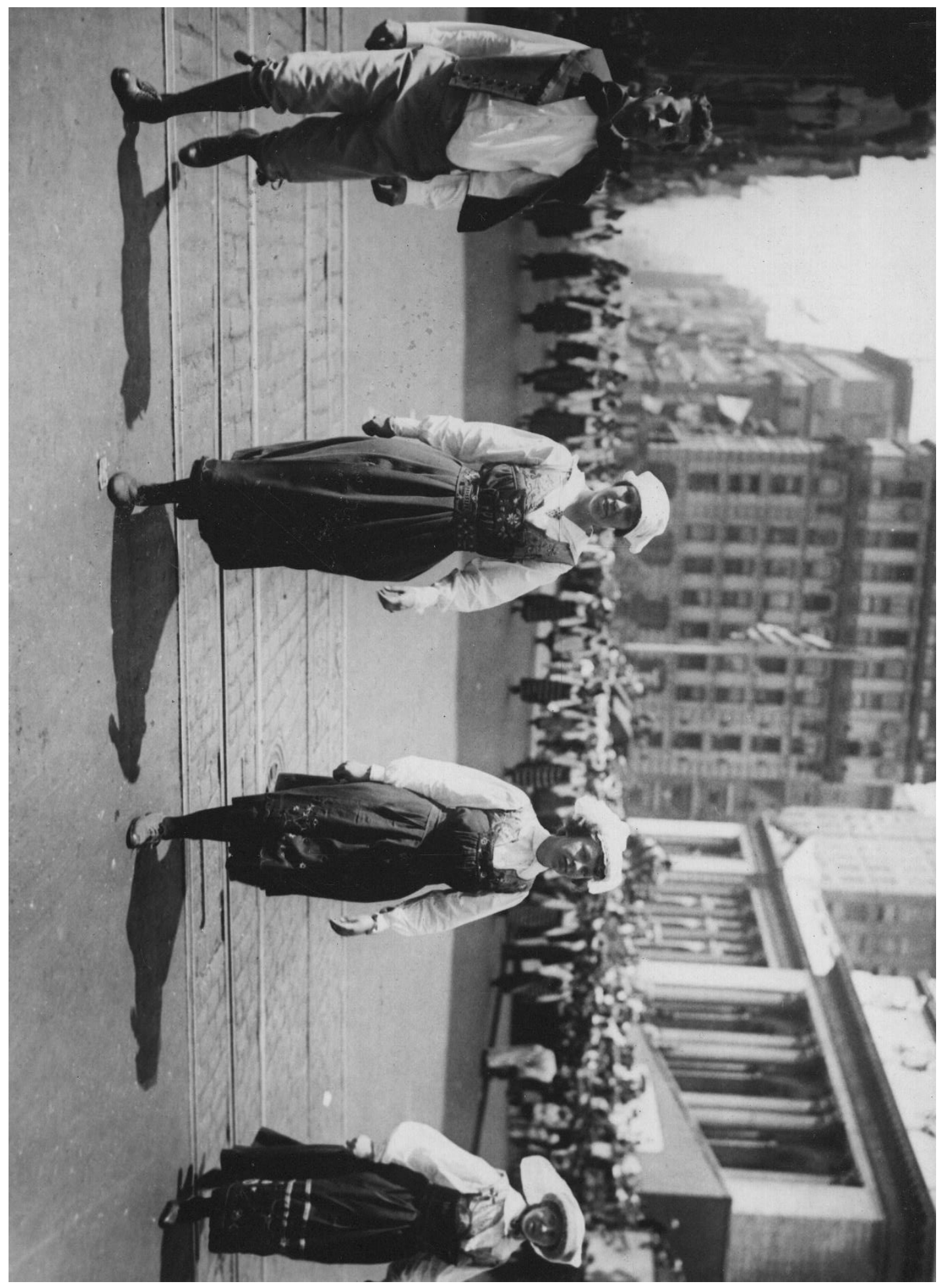

Figure 7: Swedish Americans wearing traditional folk dress in the New York parade, July 4, 1918. Und. \& Und., 165-WW-72D-82, "The Swedish Section in the Independence Day Parade, New York City, July 4, 1918," July 4, 1918. Ceremonies - Independence Day, 1918, 1917-1918, American Unofficial Collection of World War I Photographs, 1917-1918, RG 165, NACP. 
The women lay on their knees in prayer, sending thanks to the Most High that the difficulties of the journey were over, the men looking inquiringly forward toward the new country, prepared and determined to face the coming dangers and hardships, the children saw with curious eyes all the new things that laid before their eyes. The group seemed to make a very strong impression and received a sustained applause from Washington Square Park to $72^{\text {nd }}$ street. $^{212}$

A group of Swedish Americans dressed in traditional Swedish folk costumes, "rich in color and beauty," followed the symbolic settlers of New Sweden. Behind them was a second float: a model of John Ericsson's ironclad warship, the Monitor. The model was built by a John Johnson, "who, with lively applause, maneuvered the movable tower, the very essence of the ingenious invention, which once upon a time helped, or rather, perhaps made the greatest effort to save the Union." With him was a sign inscribed with the famous quotation from Ericsson's letter to Abraham Lincoln offering the use of his Monitor: "Attachment to the Union alone impels me to offer my services at this fearful crisis - my life is need by — in the great cause which Providence has called you to defend." ${ }^{213}$ Next was the Swedish section of the Red Cross, accompanied by nurses and ambulances of the Swedish Hospital, followed by Swedish boy scouts and athletes from the Swedish-American Athletic Club.

The Scandinavian section—consisting of Swedes, Norwegians, and Danes—numbered around 3,000 participants in total, and from Björkman's assessment, gave "a good idea of the contributions, past as well as present, made to [the] American cause by men and women of these races." 214

The contents of the Swedish section of the Fourth of July parade were exemplary of Björkman and the CPI's dedication to liberal Progressivism and cultural pluralism. Rather than fearing signs and symbols of ethnic affiliation, the marchers displayed their unique Swedish

\footnotetext{
212 “Svenska afdelingen I den väldiga fjärde Juli-paradaen,” Nordstjernan, July 9, 1918, 12.

213 "Svenska afdelingen I den väldiga fjärde Juli-paradaen," Nordstjernan, July 9, 1918, 12.

${ }^{214}$ Edwin Björkman, "Report on Scandinavian Fourth of July Celebrations," July 18, 1918, entry 105, box 4-5, CPI.
} 
cultural heritage through dress and song. They provided evidence for their historical contributions and sacrifices to the United States through floats depicting the colony of New Sweden and John Ericsson's Monitor, two central pieces of Swedish-American homemaking mythology consisting of their settlement alongside the "old stock" English colonists and vital service to preserving the Union. Their rich association life, benevolent institutions, and Red Cross service conveyed their continued role in American society and the war effort. The Swedish-American section argued that despite their distinct cultural identity and historical experiences, they were nonetheless Americans. The conveyance of this message was not limited to the parade's onlookers, but to their countrymen abroad as well.

From the beginning, the Committee on Public Information planned the Fourth of July celebrations with an eye to use it as propaganda abroad. Immigrants' grand displays of patriotism and dedication to American ideals across the nation made excellent propaganda material for the CPI to disseminate abroad to influence foreign public opinion. George Creel wrote how "Each race in each city had its own story to send back to its country," and Swedish Americans were among those whose participation in the celebration was sent abroad. ${ }^{215} \mathrm{~A}$ letter sent by Björkman to the heads of the CPI Foreign Section on August 16 mentioned how advance stories of the celebration did well in the Scandinavian press, however the "big story relating to the actual celebration was generally disregarded."216 This muted response contributed to Björkman's conclusion that the Scandinavian press was indifferent to news of particularly ScandinavianAmerican interest, and that for Scandinavian-American news to be interesting in Scandinavia, it “must be of general interest here." 217 This being said, the Scandinavian Bureau's representative in Stockholm, Eric H. Palmer, was of quite a different opinion. About two weeks prior, Palmer

${ }^{215}$ Creel, How We Advertised America, 246.

${ }^{216}$ Edwin Björkman, "American Cable News in Scandinavia," August 16, 1918, entry 105, box 4-5, CPI.

${ }^{217}$ Edwin Björkman, “American Cable News in Scandinavia," August 16, 1918, entry 105, box 4-5, CPI. 
wrote in a memorandum to the CPI Foreign Press Bureau about how the Swedish press was “only too eager" and "especially" anxious to get any and all Swedish American news. ${ }^{218}$ Three days after Björkman's letter, Palmer informed Edgar Sisson, head of the CPI Foreign Section, that Hvar 8 Dag (Every 8 Days), an illustrated weekly magazine in Sweden, "is using our material and the issue enclosed has run our pictures showing the Swedes in the Loyalty Parade in New York on the Fourth of July."219 On August 22, after further assessment of the Scandinavian press, Björkman wrote to the heads of the Foreign Section and Scandinavian Bureau representatives abroad, admitting to "a somewhat greater interest in Scandinavian-American news than I previously thought existed." 220

\section{Conclusion}

The 1918 Independence Day celebration dedicated to America's foreign born population was orchestrated by the Committee on Public Information with the help of CPI-backed ethnic loyalty leagues. The organization and contents of the New York parade's Swedish-American section reflects the CPI's dedication to cultural pluralism and liberal Americanization. The section was organized by the local chapter of the John Ericsson League of Patriotic Service. In a display of the marchers' Swedishness, they wore folk costumes, sang Swedish songs, and displayed the banners of their numerous religious and secular ethnic organizations. They also showcased their contributions to the making of the United States. Using key examples of Swedish-American homemaking myths as identified by Orm $\emptyset$ verland, their floats represented the foundation myth of New Sweden and the Swedish savior of the Union fleet, John Ericsson, through a model of his Monitor. Furthermore, they showed their group's sacrifice for the war

\footnotetext{
${ }^{218}$ Eric H. Palmer, "Memorandum for Foreign News Bureau, Committee on Public Information," entry 106, box 16 17 , CPI.

${ }^{219}$ Eric H. Palmer to Edgar Sisson, August 19, 1918, entry 106, box 16-17, CPI.

${ }^{220}$ Edwin Björkman, “American Cable News in Scandinavia: II,” August 22, 1918, entry 105, box 4-5, CPI.
} 
effort through members of the Swedish Red Cross. The message conveyed by the SwedishAmerican section was that of a transnational hybrid identity, composed of different elements of both the Old and New Country. In an effort to unify the nation amidst an anti-immigrant, nativist impulse during the war, the CPI intended to show the nation that foreign cultural traditions did not undermine one's loyalty to the United States and its democratic institutions. This same message was also conveyed abroad to the immigrants' homelands in an attempt to influence foreign public opinion. The CPI believed that by seeing such devotion to the ideals of Americanism by their fellow countrymen through articles and photos in the press, they would feel compelled to embrace the ideals themselves. The Fourth of July celebration thus embodied the goals of the CPI to promote cultural pluralism at home through liberal Americanization and using immigrants as subjects of propaganda to spread American ideals abroad. 


\section{CHAPTER VIII: THE SCANDINAVIAN BUREAU, PRESS WORK AND CENSORSHIP}

By the time of the 1918 Independence Day celebration, the John Ericsson League of Patriotic Service had spread across the nation, successfully creating outlets for Swedish Americans to display their patriotism and undivided loyalty to the United States. With Edwin Björkman's first task as head of the CPI's Scandinavian Bureau completed, he gave greater attention to the Swedish-American press. One of the primary purposes of the Committee on Public Information was to homogenize American public opinion through the media. The immigrant press held a distinct grip over public opinion within its representative ethnic group. Rather than further suppress the foreign language press as had already been done through the Trading with the Enemy Act, the CPI opted to work through them, supplying them with approved press material translated into their respective languages. Bureaus within the CPI's Division of Work with the Foreign Born, such as the Scandinavian Bureau, were tasked with this work. This approach of cooperation rather than suppression further highlights the CPI's liberal approach toward Americanization and dedication to cultural pluralism.

The Swedish-American press was a vital resource for Swedish immigrants to obtain information relevant to their life in the United States as well as updates about conditions back in Sweden. The fact that this press was only intelligible to Swedish Americans and not to the broader American public was cause for suspicion during the war. The Swedish-American press was in fact largely pro-German before American belligerence, and though they silenced their open critique of American war policy, there were still editors sympathetic to the German cause

and the issue of pro-German news coming in from the Swedish press abroad. Björkman, as head of the Committee on Public Information's Scandinavian Bureau, went to work to ensure that the 
message of the Swedish-American press was wholly American in its presentation and interpretation of the news, even if it necessitated the use of coercive methods.

This section will first provide an overview of the work conducted by Björkman and the Scandinavian Bureau's press office in New York in translating, writing, and disseminating CPI propaganda material throughout the Scandinavian-American press. It will then discuss Björkman's use of coercive power through the Trading with the Enemy Act to ensure the loyalty of the Swedish-American press. This involved primarily his control over issuing permits giving foreign language papers permission to publish articles on the war and politics without having to file an English translation with the postmaster general. Lastly, this section will look at a case study involving a pro-German article published in the Augustana Synod's youth magazine, Ungdomsvännen (The Friend of Youth). At the end of this controversy, Björkman received commitments from Synod leaders that they would fall in line with his Bureau's mission to Americanize Swedes and promote an undivided loyalty to the United States, all but completing his work among Swedish Americans.

Through this work, Björkman attempted to further root out Swedish Americans' political ties to Sweden and sympathy for Germany by influencing the information they consumed through the press. It is important to note that such was not an attack on Swedish cultural identity. Björkman made a clear distinction between ethnic and political identity; his goal was solely to promote undivided political loyalty to the United States. This press work also had implications for Swedish-American transnational relations, as Björkman actively sought to correct misrepresentations in the Swedish press and produce pro-American content that would make its way back to Sweden. 


\section{Press Work}

Located at 235 west twenty-third street, New York City, Björkman staffed the Scandinavian Bureau's office with a team of translators in the three Scandinavian languagesSwedish, Norwegian, and Danish—as well as Finnish and Dutch later in the war. His staff included Olof P. Zethelius, later H. Gude Grinndal, Swedish department; Harry Sundby-Hansen, Norwegian department; Roger Nielsen and later Viggo C. Eberlin, Danish department. Other employees included those necessary to the smooth-running of any press office: a secretary, stenographer, office manager, and agents in the field. ${ }^{221}$

In order to ensure that his office be best equipped to conduct the CPI's propaganda and Americanization work, Björkman needed qualified Scandinavian-American journalists possessing an undivided loyalty to the United States. The translators employed by the Bureau were Scandinavian immigrants fluent in their respective languages and had experience working in the Scandinavian-American press: Zethelius was previously employed by Svenska Amerikanska Posten; Grinndal was an editor for Nordstjernan; and Sundby-Hansen was a contributor to Nordisk Tidende. ${ }^{222}$

Björkman investigated the backgrounds of potential employees to assess their skills, character, and loyalty to the American cause. After meeting with the Swedish-American Eric H. Palmer, who became the Bureau's representative in Stockholm, Björkman noted his twelve years of journalistic experience, his fluency in Swedish, and his American wife "who rather distrusts

\footnotetext{
${ }^{221}$ Edwin Björkman, "Report on Scandinavian Bureau, Committee on Public Information," May 31, 1918, entry 105, box 4-5, CPI. Edwin Björkman, "Report on the work of the Scandinavian Bureau, from October 31 to November 26," November 29, 1918, entry 105, box 4-5, CPI. Other named individuals include Robert E. Lee as assistant director and L. G. Dorrman as stenographer.

222 "Afliden tidningsman," Svenska Amerikanaren, October 24, 1918, 11; Vilhelm Berger, Svenskarne i New York (New York: Waldemar J. Adams \& Co., 1918), 41; "Harry Sundby-Hansen, Boro Journalist, Dies" Brooklyn Daily Eagle (Brooklyn, New York), September 13, 1946, 3.
} 
everything Swedish." 223 In contrast, when looking to put a man in Norway, Björkman rejected Palmer's recommendation of the renowned Norwegian-American artist Ben Blessum due to his weak journalistic background, his aversion "to any discipline" from former employers, and his "sharp criticisms on American life and institutions."224

For those Björkman hired, he noted their dedication to both the Scandinavian Bureau's work and America's cause. In mid-October, Björkman's Swedish translator, Olof P. Zethelius, suddenly died of pneumonia. Björkman wrote how, "There is little doubt that his habit of constantly overworking has been partly responsible for his death," and that he had "given his life for this country as much as if he had fallen on the field of battle."225

The content of the Scandinavian Bureau's press work included translations of general CPI material as well as material prepared by the Scandinavian Bureau's staff specifically for Scandinavian Americans. In a memorandum detailing the Bureau's work in June 1918, Björkman stated that $51 \%$ of his office's material was translated from English into Swedish, $43 \%$ written in the office, and 5\% used as obtained from the author. ${ }^{226}$ The press material translated by the Scandinavian Bureau included events pertaining to the war abroad, domestic war preparations, statements by government officials, speeches by President Wilson, details of Wilson's peace program, and general patriotic materials. The Bureau also translated material for other CPI divisions, such as photo captions, movie titles, and cables, as well as memorandums for other government departments. ${ }^{227}$

\footnotetext{
${ }^{223}$ Edwin Björkman to Will Irwin, April 3, 1918, entry 105, box 4-5, CPI.

${ }^{224}$ Edwin Björkman to Edgar Sisson, September 11, 1918, entry 105, box 4-5, CPI.

${ }^{225}$ Edwin Björkman to Edgar Sisson, October 14, 1918, entry 105, box 4-5, CPI; Edgar Sisson to Eric Palmer, October 15, 1918, file 103.93/1125a, box 735, CDF, RG 59.

${ }^{226}$ Edwin Björkman, "Memorandum for Mr. Poole," June 28, 1918, entry 105, box 4-5, CPI.

${ }^{227}$ Edwin Björkman, "Report on the work of the Scandinavian Bureau, from October 31 to November 26," November 29, 1918, entry 105, box 4-5, CPI.
} 
Important to the effectiveness of this press material was it being communicated in the language Swedish-Americans understood best—-the Swedish language. Wartime nativism saw attacks on foreign language use in United States, exemplified by Iowa Governor William Lloyd Harding, who on May 23, 1918 issued the "Babel Proclamation," banning the use of any language other than English in public, including schools, churches, trains, and telephones. Nebraska followed in April, issuing the Siman Act which restricted the teaching and study of foreign languages in schools. ${ }^{228}$ Björkman complained to Creel about these restrictions, fearing that they would make his work of fostering patriotic feeling and encouraging activity among Swedish Americans more difficult. ${ }^{229}$ Historians have suggested that Björkman's letter might have prompted Creel's letter to President Wilson on August 6. Creel complained that such bans impeded the CPI's work among immigrants, which had been "so vitally necessary and so rich in results already." If such bans must be put in place, he stressed to the President that they should exempt the languages of neutral nations, such as those of Scandinavia. ${ }^{230}$

Björkman's staff tailored the Scandinavian Bureau's material specifically for Scandinavian-American audiences. Björkman listed the topics of such articles in his June memorandum, including "Editorials written by prominent Swedish Americans, SwedishAmerican patriotic news, Scandinavian news, ... [and] refutations of pro-German propaganda." ${ }^{231}$ To obtain statements by leading Swedish Americans, Björkman prepared a letter "To Our Leading Citizens of Swedish Blood," imploring them to write articles making clear to both Swedish Americans and Swedes in Sweden that the United States is "united," "determined

\footnotetext{
${ }^{228}$ Chrislock, Ethnicity Challenged, 117.

${ }^{229}$ Edwin Björkman to George Creel, July 17, 1918, entry 105, box 4-5, CPI.

${ }^{230}$ George Creel to Woodrow Wilson, August 6, 1918, in Arthur S. Link, ed., The Papers of Woodrow Wilson. Vol. 49 (Princeton: Princeton University Press, 1985), 200-1. Hamilton, Manipulating the Masses, 221; Lindmark, Swedish America, 105.

${ }^{231}$ Edwin Björkman, “Memorandum for Mr. Poole,” June 28, 1918, entry 105, box 4-5, CPI.
} 
to carry the war to a successful finish," and that if Sweden "let herself be lured into joining our enemies, the Swedes of this country will not hesitate to oppose her with arms in hand, if need be."232 This statement shows Björkman's transnational understanding of Swedish-American public opinion in that the opinions of its leadership had the capacity to influence public opinion back in Sweden. This message communicated how Björkman believed that if the Swedes knew that their countrymen abroad would not support belligerency on the side of Germany, they might be less inclined to make such a decision.

In a follow-up letter, Björkman again made this request, asserting that "We must do our utmost to bring every loyal citizen into line for the national war policy. We must do as much to bring the few disloyal or misguided ones to terms." He concludes his letter with "Don't hesitate for fear of strengthening 'the hyphen'. Clannishness is an evil and divided allegiance a crime, but recognition of natural ties for patriotic purposes is both a right and a duty." 233 Björkman thus sees Swedish-American ethnic affiliation not as divided loyalty, but as a valuable "natural" network which can be used to contribute to the American war effort.

One feature of the Scandinavian Bureau's propaganda were articles about Scandinavian American soldiers. The Worcester, MA paper Svea published a column distributed by the Scandinavian Bureau entitled "Vår 'Honor Roll”, (“Our 'Honor Roll’”), which listed the names and hometowns of deceased soldiers of Scandinavian descent. ${ }^{234}$ Another article in Svea from the Bureau listed the names of Scandinavian-American soldiers decorated with the Distinguished Service Cross by General Pershing. ${ }^{235}$ Correspondence within the Scandinavian Bureau also

\footnotetext{
${ }^{232}$ Edwin Björkman, “To Out Leading Citizens of Swedish Blood,” March 1918, entry 105, box 4-5, CPI. This request was in direct response to the German invasion of the Aaland Islands, a Finnish territory with a sizeable Swedish population. When the Swedish army relinquished control over the islands to the German army, Björkman feared that Sweden would join the war on the side of Germany.

${ }^{233}$ Edwin Björkman, "Confidential circular \#2," April 29, 1918, entry 105, box 4-5, CPI.

${ }^{234}$ See example: "Vår 'Honor Roll'," Svea, November 20, 1918, 10.

${ }^{235}$ See example: "Distinguished Service Cross," Svea, July 17, 1918, 9.
} 
mentioned the publishing of letters and photos of "Scandinavian-American soldiers at the front." 236 This propaganda proved most effective both domestically and in Scandinavia as it displayed the dedication and sacrifices made by Scandinavian Americans for the American cause. As more husbands, sons, grandsons, and friends served, and the human cost of the war became more visible, Scandinavian Americans naturally became more militantly anti-German. ${ }^{237}$

The Scandinavian Bureau also made direct attempts to combat the lies, misrepresentations, and rumors perpetuated by German propaganda. The Minneapolis paper Svenska Amerikanska Posten featured a series from the Scandinavian Bureau called “Tyskvänliga Lögner” (“German-Friendly Lies”), which featured a numbered list of "lies” relating to the American war effort or domestic situation followed by refutations as an “answer." ${ }^{238}$ Björkman himself published a lengthy article refuting a piece of German propaganda making its rounds through the Swedish press regarding the selective service. The propaganda claimed that the United States drafted unnaturalized citizens of neutral countries, something to which the Swedish government protested against. In his article "Neutral Subjects Within the Draft," Björkman explained that any Swede who began the process of naturalization and received their "first papers" swore an oath of allegiance to the nation, received some rights of citizenship such as the vote, and also was subject to the draft. Björkman requested a statement on the topic from a leading Swedish American to provide added weight to the statement. John Lind, a former governor of Minnesota and a member of the John Ericsson League of Patriotic Service's National Council, provided a statement, asserting that if Swedes want to become American citizens, "they must accept the same burden and responsibilities as the other members

\footnotetext{
${ }^{236}$ Edwin Björkman to Eric H. Palmer, August 20, 1918, entry 106, box 16-17, CPI.

${ }^{237}$ Lindmark, Swedish America, 83.

238 See example: “Tyskvänliga Lögner,” Svenska Amerikanska Posten, June 19, 1918, 10.
} 
of the family. If they do not they can remain as strangers and aliens and have the protections of our laws so long as they observe them.",239

Lastly, pertaining to the transnational relationship between Scandinavian-Americans and Scandinavians, the Scandinavian Bureau provided the Scandinavian-American press with news about the political, economic, and social situations in Scandinavia. Scandinavian-American audiences continued to be interested in life back in the Old Country, particularly regarding the impact of and responses to the war. Much of this information was gleaned from the Scandinavian press itself. Scandinavian-American editors received copies of Scandinavian newspapers through the mail, then reprinted or adapted the stories for their own publications. As has been explained previously, in the Swedish case, such articles could be biased in favor of the Germans due to propaganda abroad, the Germans buying papers or space in them, or the sympathies of Swedish editors. Björkman believed that such news influenced Swedish-American public opinion regarding Sweden's relationship with the belligerents and the sympathies of the Swedish people. It was therefore the duty of the Scandinavian Bureau to supply the Scandinavian-American press with "correct" interpretations of events abroad.

In order to effectively present a CPI-approved view of the situation in Scandinavia, Björkman needed to get his hands on the news himself, ideally before the ScandinavianAmerican press. As early as February 1918 Björkman requested help from the American Legations in Scandinavia to assist him by subscribing to the papers and sending them to him via diplomatic pouch so that they would arrive sooner than by regular mail. ${ }^{240}$ By getting the most

\footnotetext{
${ }^{239}$ Edwin Björkman, "Neutral Subjects Within the Draft," Charlotte News (Charlotte, North Carolina), September 1, 1918, 15; "Provisional Constitution of the John Ericsson League of Patriotic Service," Swenson Archives, MSS 123, Box 1, Folder 13, Jules G. U. Mauritzson Papers, Swenson Swedish Immigration Research Center Archives, Rock Island, Illinois.

${ }^{240}$ Edwin Björkman to Arthur Woods, February 28, 1918, entry 105, box 4-5, CPI; Edwin Björkman to Will Irwin, April1, 1918, entry 105, box 4-5, CPI.
} 
current news early, Björkman could correct their interpretation of events, refute propaganda before it takes root, and gain valuable intelligence about the situation abroad to inform his next steps. Björkman explained the importance of getting this news to Will Irwin, stating "the whole Swedish work here is depending on knowing what the Swedish papers are printing."241

When the strategy worked properly, Björkman was elated, writing how "The first papers that arrived in that way beat the regular mails by more than three weeks and we had the Scandinavian-American press wild with excitement over the quick news they got from us. In this way I am particularly able to correct the Swedish-American conception of Swedish politics."242 The strategy, however, did not always work. Björkman often voiced his frustration through to the end of the war that Scandinavian papers continued to arrive too late if at all for them to be of great use to him. ${ }^{243}$ While the method was not perfect, it did provide the Scandinavian Bureau with a certain degree of control over the flow of information coming in from Scandinavia; as Björkman wrote, "II am now able to give the Scandinavian press correct information about political happenings over there, and I may say that this is the first time in history that they have had such information." 244 The fruits of such work was seen in columns such as "Senaste Nyheter Från Sverige" ("Latest News from Sweden") in Svea. ${ }^{245}$

The press office of Edwin Björkman's Scandinavian Bureau produced propaganda to strengthen Swedish-American political loyalties to the United States. They published statements of Swedish-American leaders, refuted German propaganda, and provided an interpretation of Scandinavian political events that replaced a pro-German bias with a pro-American and pro-

\footnotetext{
${ }^{241}$ Will Irwin to Philip Patchin, April 3, 1918, entry 105, box 4-5, CPI.

${ }^{242}$ Edwin Björkman to Eric H. Palmer, July 3, 1918, entry 106, box 16-17, CPI.

${ }^{243}$ Edwin Björkman to Eric H. Palmer, August 14, 1918, entry 106, box 16-17, CPI; Edwin Björkman to Edgar Sisson, October 4, 1918, entry 105, box 4-5, CPI.

${ }^{244}$ Edwin Björkman to Robert Rudd Whiting, June 15, 1918, entry 105, box 4-5, CPI.

245 See example: "Senaste Nyheter Från Sverige," Svea, July 10, 1918, 9.
} 
democratic one. This work is rooted within the transnational relationship between Swedes in America and Swedes in Sweden, where the circulation of information between them had the ability to influence each other's public opinion. Björkman's efforts were to control this flow of information to root out political loyalty to Sweden while at the same time affirming ethnic affiliation for patriotic and propagandistic purposes. The production of propaganda material by Björkman's office was not enough to root out pro-German sympathies and a Swedish political worldview from the Swedish-American press, and therefore Björkman sometimes had to resort to more strong-arm methods.

\section{Björkman and the Censorship of the Swedish-American Press}

President Wilson and George Creel created the Committee on Public Information as an alternative to wholesale censorship to preserve the American constitutional freedom of the press. Creel pursued "voluntary censorship," in that editors across the nation would agree to not publish sensitive war information or seditious materials for the good of the war effort and national unity. The CPI would in turn serve as an advisor for which stories were safe to publish as well as supply the press with official information. This being said, with the passing of the Espionage Act, Trading with the Enemy Act, and the Sedition Act, there was a threat of legal action against publishing material critical of the administration, thus making self-censorship feel less than voluntary.

The most impactful of these pieces of legislation on the foreign-language press was the Trading with the Enemy Act of 1917. Under this act, if a foreign-language newspaper contained an article on any government involved in the war, its policies, relations, or conduct, it must submit an English translation of it with the postmaster general otherwise the paper would not be 
circulated through the mail. ${ }^{246}$ Writing such translations was time consuming and costly, as papers might have to hire additional staff to prepare them. For small papers with a limited circulation, further impacted by anti-immigrant sentiments as a result of the war, such additional costs caused them to cease publication entirely. A paper could, however, receive a special permit exempting them from filing translations if they proved their unquestioned loyalty to America's cause. The CPI's Foreign Language Newspaper Division, which merged with the Division of Work with the Foreign Born in May 1918, was tasked with monitoring the foreign-language press for violations of the Trading with the Enemy Act and issuing permits. ${ }^{247}$ This effectively gave the CPI censorship power over the immigrant press in America; while papers could continue to publish without a permit, it would cost them, and not all could bear the cost. Early in his employment with the CPI has head of the Scandinavian Bureau, Edwin Björkman took control of this censorship power for the Swedish-American press. Sture Lindmark argues that Björkman overly scrutinized and threatened them, applying his censorship powers arbitrarily, sometimes in response to personal criticism. ${ }^{248}$ While Björkman was deeply concerned about the loyalty of his fellow Swedish Americans and did not hesitate to use his censorship powers against disloyal papers, the application of this power was not arbitrary. Björkman's primary goal in the Scandinavian Bureau was to cement the political loyalty of Swedish Americans. His censorship powers allowed him to coerce the press into affirming their loyalty to the United States, ceasing publication of even the most subtle pro-German articles, and agreeing to publish the Scandinavian Bureau's material. Björkman's secondary goal was to influence public opinion back in Sweden. Knowing that Swedish-American papers and stories made their way back to Sweden, the impression therein must be that of an undivided America;

\footnotetext{
${ }^{246}$ Mock and Larson, Words That Won the War, 45.

${ }^{247}$ Vaughn, Holding Fast the Inner Lines, 201.

${ }^{248}$ Lindmark, Swedish America, 112-14.
} 
one nation of different peoples unified in their devotion to the nation, its ideals, and its mission to bring about peace and democracy.

In mid-April 1918, Björkman wrote to Carl Byoir, associate chairman of the CPI, asking for a list of all Swedish-American newspapers that received permits under the Trading with the Enemy Act. Björkman expressed that some "doubtful” publications had received permits and asked that "no further licenses be granted without being first referred to me." 249 He received a list of fifty Swedish-American papers, listing the paper's content (political, religious, war news), trustworthiness ("Seems O.K.," "To be watched"), and if they had received a permit. ${ }^{250}$

The issuing of permits to Swedish-American papers was then at Björkman's discretion. In looking through his correspondence, it is apparent that Björkman issued permits to papers who had demonstrated their loyalty and used Scandinavian Bureau material. He was also sympathetic to papers experiencing financial hardship. In one instance, the manager and editor of the Iowa Posten of Des Moines, Iowa, E. Enstrom, wrote to Björkman nearly begging for a permit. Björkman had previously believed that the paper published articles on war matters without filing translations with the postmaster general, a violation of the Trading with the Enemy Act. ${ }^{251}$ Enstrom explained in his letter that they had in fact filed the translations, but such was not indicated in the articles due to staffing and financial issues wreaking havoc in their office. He was eager to publish the Scandinavian Bureau's "patriotic propaganda" however the necessity of providing translations had drained his "strength and time." He then made a case to prove his devotion to the American cause. While the previous owner, Mr. Alarik, was pro-German before the American declaration of war, Enstrom asserted that he was “"violently' anti-German, proAmerican, pro-French and pro-British from the first outbreak of the European war," detesting the

\footnotetext{
${ }^{249}$ Edwin Björkman to Carl Byoir, April 12, 1918, entry 105, box 4-5, CPI.

250 "Swedish Newspapers," entry 105, box 4-5. CPI.

${ }^{251}$ Edwin Björkman to Carl Byoir, August 20, 1918, entry 105, box 4-5, CPI.
} 
German invasion of Belgium and the sinking of the Lusitania. He further noted that he had two sons in France, "both volunteered, encouraged by me." Enstrom concluded his letter writing:

This is a long and not very businesslike letter, Mr. Björkman, but when started on this matter it is hard to stop. It really feels very bitter to be bound by hand and foot like this when I have proved to be a more intense American than most native born and when I know that I could do a much better patriotic service if unhampered by the translation rules. ${ }^{252}$

Following Enstrom's letter, Björkman wrote to Byoir requesting that the Iowa Posten be granted a permit, as they were "anxious to print our stuff" and that "there cannot be the slightest question about its loyalty." 253

In some cases, Swedish-American papers had already received permits, but published pro-German articles. In one instance showing the harm done by Swedish newspapers coming to the United States, Nordstjernan published an article entitled "A Noteworthy Revelation of Russia's Plans." The article discussed the sensitive topic of Finland and quoted Aftonbladet, a Stockholm paper which Björkman "regarded as German, rather than pro-German." Björkman acknowledged that Nordstjernan "was pro-German until we got into the war," however this article was "a relapse having nothing to do with the general attitude of the paper." Björkman intended to have a "heart-to-heart talk" with the paper's publisher Charles K. Johansen on the issue. Johansen, a member of the John Ericsson League of Patriotic Service's National Council, had been generously handling the Scandinavian Bureau's material and was not punished for this mistake. $^{254}$

Despite Björkman's understanding that Swedish-American newspaper editors should not be blamed for their pre-war pro-Germanism, he did not issue permits to the Swedish-American

${ }^{252}$ E. Enstrom to Edwin Björkman, August 15, 1918, entry 105, box 4-5, CPI.

${ }^{253}$ Edwin Björkman to Carl Byoir, August 20, 1918, entry 105, box 4-5, CPI.

254 "Provisional Constitution of the John Ericsson League of Patriotic Service," Swenson Archives, MSS 123, Box 1, Folder 13, Jules G. U. Mauritzson Papers, Swenson Swedish Immigration Research Center Archives, Rock Island, Illinois; Edwin Björkman to Carl Byoir, August 14, 1918, entry 105, box 4-5, CPI. 
press liberally. In the case of Skandia of Jamestown, NY, Björkman was hesitant to issue them a permit on account of some "questionable" articles and their supposed refusal to publish any of the Scandinavian Bureau's material. It was not that the paper was disloyal in Björkman's eyes, but in their reporting of global events "both the tone of its material and its arrangements suggests a Swedish, rather than an American, point of view." 255 This issue was that when the editor assessed global events, he did so from the perspective of a Swede rather than as an American with wholly American concerns. It was this exact attachment to Sweden as a nation-a political, social, and economic entity — that Björkman tried to eliminate among Swedish-Americans. Furthermore, their apparent unwillingness to work with the Bureau made Björkman wary of their motives. Reverend John Emmanuel Hillberg of Jamestown responded to an inquiry from Björkman regarding Skandia, wherein he affirmed the paper's loyalty. Much like with the Iowa Posten, the publisher, Mr. Lindstone, lacked funds to translate the articles supplied by the Scandinavian Bureau. Hillberg assured Björkman that Lindstone would be glad to use the Bureau's material if he could only be issued a permit to publish without having to file translations. ${ }^{256}$ Provided with this information, Björkman requested that Skandia be issued a permit. $^{257}$

In another instance, Björkman attempted to revoke the permit of the Worcester, MA paper, Svea. Around mid-April 1918, Björkman learned that Svea had welcomed back Carl G. Fredin to their editorial staff, a man he regarded as "one of the most brazen pro-Germans of the Swedish-American press." 258 The rehiring of Fredin alone was not enough for Björkman to take

\footnotetext{
${ }^{255}$ Edwin Björkman to John Emmanuel Hillberg, August 10, 1918, entry 105, box 4-5, CPI.

256 John Emmanuel Hillberg to Edwin Björkman, August 17, 1918, entry 105, box 4-5, CPI.

${ }^{257}$ Edwin Björkman to Carl Byoir, August 20, 1918, entry 105, box 4-5, CPI.

${ }^{258}$ Edwin Björkman to Carl Byoir, April 18, 1918, entry 105, box 4-5, CPI.
} 
steps to revoke their permit, however, but the paper was under close observation. ${ }^{259}$ The catalyst for Björkman's strong reaction was Svea's critical report on his speech given in Worcester on April 8, 1918. ${ }^{260}$ In the speech, Björkman acknowledged the pro-German elements within Swedish America, saying how there was treason "sneaking about at night, whispering lies," and sometimes these lies were spoken in Swedish. This statement caused a strong reaction in Svea. In the article published two days later, they quoted this small portion of Björkman's speech and rejected the insinuation that Swedish Americans were disloyal or treasonous, asserting in bolded text "Swedish-Americans are neither nightmen (nattmän) or traitors." ${ }^{261}$ It was this strong critique and selective quoting of his speech, in addition to their pro-German editor, that caused Björkman to begin the process of revoking Svea's permit. ${ }^{262}$ Such reporting on his activities had the potential to alienate numerous Swedish Americans from the Scandinavian Bureau's work. Björkman wrote to Anton H. Trulson, publisher of Svea, informing him of his decision. Trulson responded stating that a fire had occurred in their printing plant on April 4, limiting the number of issues they could published and therefore limiting space, resulting in them being unable to publish the entirety of Björkman's speech. The publisher apologized on behalf of his editor if Björkman had been misquoted and promised that his entire speech would be published in the following issue of the newspaper. Trulson then affirmed his paper's loyalty and admitted that "Mr. Fredin together with probably about ninety percent of the Swedes of America were

\footnotetext{
259 “Swedish Newspapers," entry 105, box 4-5. CPI.

260 “Address given by Mr. Edwin Björkman at Worcester, Mass., April 8, 1918,” 3070, folder 302, Edwin Björkman Papers, Southern Historical Collection, The Wilson Library, University of North Carolina at Chapel Hill.

261 "Det Svenska frihetsmötet," Svea, April 10, 1918, 1.

${ }^{262}$ Edwin Björkman to Carl Byoir, April 18, 1918, entry 105, box 4-5, CPI. Sture Lindmark characterized Björkman's response as a reaction against a personal attack, failing to note Björkman's previous suspicions of Fredin. While the article was the catalyst for the revocation, it was not the sole cause. The article was also not a purely innocent critique as it misrepresented his message and threatened to undermine his work with the CPI. For a similar critique of Lindmark's characterization of Bjorkman and this event, see Gustav Jonasson's review of Lindmark's book in American Swedish '73, ed. Leif Sjoberg (Philadelphia: American-Swedish Historical Foundation, 1973), 52.
} 
prejudiced with Germany in the early days of this war, but as conditions have changed Mr.

Fredin and the greatest percentage of these Swedes have changed also."263 Björkman responded to Trulson's letter, stating that he was satisfied with his whole speech being published in the paper and that he would send a recommendation to Washington for Fredin to be given another chance. Ending with a warning, he wrote "There is a great deal of distrust of his [Fredin's] attitude, and he will have to be very careful in order to dispel it." ${ }^{264}$

The threat of revoking a paper's permit was an effective tool for silencing pro-German and pro-Swedish viewpoints — or at least making editors aware of their unconscious biases — as well as spurring the papers into more intense patriotic activity. The next case study will further reveal that the utility of this power was not lost on Björkman, as he employed it with intent against one of Swedish America's most influential cultural institutions: the Augustana Synod.

\section{Björkman and the Augustana Synod}

The final example of Edwin Björkman's censorship power exercised through the CPI's Scandinavian Bureau centers around the Augustana Synod of the Lutheran Church. The Augustana Synod, formed in June 1860, was one of the most organized and prolific Swedish cultural institutions, spawning colleges, a publishing house, periodicals, and over one thousand congregations across the nation. Furthermore, its leaders and institutions played a central role in the creation of a Swedish-American identity, as explored in Dag Blanck's The Creation of an Ethnic Identity. In 1915, the Synod boasted 274,000 members, and emerged as the "dominant ethnic ideology" for Swedish Americans. ${ }^{265}$ For these reasons, securing the loyalty and cooperation of the Augustana Synod was of vital importance for Edwin Björkman's work. The loyalty of the Synod was, however, questionable.

\footnotetext{
263 Anton H. Trulson to Edwin Björkman, May 5, 1918, entry 105, box 4-5, CPI.

${ }^{264}$ Edwin Björkman to Anton H. Trulson, May 7, 1918, entry 105, box 4-5, CPI.

${ }^{265}$ Blanck, The Creation of an Ethnic Identity, 25, 36.
} 
Before American entry into the war, the Augustana Synod sent a resolution to President Wilson demanding true neutrality through an embargo of arms and munitions to belligerents. ${ }^{266}$ Ceasing the supply of war materials for the Allies was often regarded as a result of pro-German sympathies. The Synod's Lutheranism was also cause for suspicion, as Germany was the home of Martin Luther. Furthermore, some of their clergymen had also expressed a pro-German stance prior to American entry as well. ${ }^{267}$ While the Augustana Synod professed a wholly loyal and patriotic position following the American declaration of war, there persisted a perception of disloyalty among their ranks. By possessing such a significant grip over Swedish America, Björkman sought to cement the Synod's loyalty and encourage more intense patriotism.

From the beginning of his work with the CPI, Björkman worked to establish a relationship between his bureau and the Augustana Synod. Upon the formation of the John Ericsson League of Patriotic Service, Björkman placed Gustav Andreen, president of Augustana College in Rock Island, IL, on the Executive Committee. Additionally, Björkman and Andreen formed a local Rock Island council of the JELPS in March 1918. While Björkman had the cooperation of influential members of the Synod, an issue arose at the end of March.

In an issue of the Augustana Synod's journal Ungdomsvännen (The Friend of Youth) appeared an article by pastor A. M. L. Herenius entitled "Svensk reformation" ("Swedish Reformation"). The article discussed the Protestant Reformation in Sweden led by Olof Persson. ${ }^{268}$ In the article, Herenius wrote how Sweden's Protestant religion originated from Germany, not Rome. He stated that the Swedish people are Germanic but are distinct due to

\footnotetext{
${ }^{266}$ Lindmark, Swedish America, 73.

${ }^{267}$ Lindmark, Swedish America, 79-81.

${ }^{268}$ Latin: Olaus Petri
} 
being "the purest branch of the Germanic folk tree." ${ }^{269}$ Martin Luther's theology spoke to the "Germanic soul" more so than Catholicism. As Persson spread Protestantism across Sweden, it took on a uniquely Swedish character, forming a uniquely Swedish spirituality; "Of course, the Swedish Reformation came from Germany, but the Swedish Reformation did not become German. ${ }^{, 270}$ While Herenius argued that Swedes were distinct from Germans racially and spiritually, they were nonetheless Germanic. From this discussion, it is not farfetched for readers to assume that Swedes should have sympathy for Germany in the current war due to these close historical and religious relationships.

Upon catching wind of this "rather offensive" article, Edwin Björkman saw it as "a means of scaring up the church and getting its leaders to start some enthusiastic patriotic work from the inside. ${ }^{271} \mathrm{He}$ wrote to Andreen indicating that it was his first inclination to report the article to Washington but contacted him first as "to harmonize and take away suspicions which might exist. ${ }^{.272}$ Andreen explained in his response that he immediately called a meeting of the Executive Board of the Augustana Book Concern (ABC), the publishing house of the Augustana Synod where they "repudiated absolutely the sentiments expressed in the article." At the meeting they criticized and suspended the editor of Ungdomsvännen, then agreed that the contents of the journal would be "positively and constructively patriotic," giving "the government loyal and devoted support." ${ }^{273}$ Grant Hultberg, manager of the ABC, also wrote Björkman about the journal's new overtly patriotic position alongside a request for a permit to publish without filing translations with the post office. ${ }^{274}$ This response was "exactly" what Björkman had hoped for. It

\footnotetext{
${ }^{269}$ A. M. L. Herenius, “Svensk reformation.," Ungdomsvännen (Rock Island, Augustana book Concern, March 1918), 58.

${ }^{270}$ Herenius, "Svensk reformation.," 58.

${ }^{271}$ Edwin Björkman to Carl Byoir, April 1, 1918, entry 105, box 4-5, CPI.

${ }^{272}$ Gustav Andreen to Edwin Björkman, March 28, 1918, entry 105, box 4-5, CPI.

${ }^{273}$ Gustav Andreen to Edwin Björkman, March 28, 1918, entry 105, box 4-5, CPI.

${ }^{274}$ Grant Hultberg to Edwin Björkman, March 28, 1918, entry 105, box 4-5, CPI.
} 
was Björkman's expressed intention to “turn the Swedish Lutheran Church into a militant patriotic body." ${ }^{275}$ Meeting Hultberg's request, Björkman recommended that Ungdomsvännen be issued a permit.

Following this incident, Björkman received several assurances of loyalty and cooperation from the Augustana Synod as well as updates on their patriotic activities. Rev. Dr. Gustaf Albert Brandelle, President of the Augustana Synod, informed Björkman that Synod leaders "will do everything in their power to swing the Swedish Lutheran Church into line on the right side."276 Among the measures taken by the Synod, they put pressure "on any pastor that has been here [in the United States] long enough without becoming an American citizen," and indicated a willingness to "resort to strong disciplinary measures" on any pastor or employee found to be "recalcitrant or disloyal." 277 Given that Brandelle had promised Björkman "his full cooperation in swinging [the Augustana Synod] into line for the national war policy,” Björkman requested that another Synod publication, Augustana, be given a permit to publish without filing translation as to further cement friendly relations between their organizations. ${ }^{278}$

In mid-June 1918, the Augustana Synod hosted its Annual Convention, and used the event as an opportunity to push for stronger patriotism among its members and fall closer in line with Björkman’s Scandinavian Bureau. The convention saw over 11,000 participants, with Swedish-American representatives from most states. P. O. Bersell, vice president of the Lutheran Brotherhood of America, told Björkman how the event was "teeming with spontaneous enthusiasm and patriotism;" "Many say it was the greatest meeting the Augustana Synod ever

\footnotetext{
${ }^{275}$ Edwin Björkman to Carl Byoir, April 1, 1918, entry 105, box 4-5, CPI.

${ }^{276}$ Edwin Björkman to Carl Byoir, April 12, 1918, entry 105, box 4-5, CPI.

${ }^{277}$ Edwin Björkman to George Creel, April 12, 1918, entry 105, box 4-5, CPI; Edwin Björkman to Carl Byoir, April 12, 1918, entry 105, box 4-5, CPI.

${ }^{278}$ Edwin Björkman to Carl Byoir, April 22, 1918, entry 105, box 4-5, CPI; Edwin Björkman to Carl Byoir, April 25,1918 , entry 105 , box $4-5$, CPI.
} 
held." The synod passed a resolution to "give our government the greatest possible assistance in our great struggle for the freedom of the world." Bersell explained to Björkman that "our intention is thereby to 'line up' with your Bureau in any and every way that you may suggest."279 In a letter to Byoir, Björkman expressed his satisfaction with the Augustana Synod's actions. Getting such a tremendously influential institution among Swedish Americans to act in full cooperation with his Scandinavian Bureau was a major step forward for completing his goals; "This action on the part of the Annual Convention of the Swedish Lutheran Church means a very great deal to the final consolidation of a patriotic front of our American citizens of Swedish descent." ${ }^{280}$

\section{Conclusion}

As the name suggests, the Committee on Public Information was first and foremost an agency devoted to controlling information consumed by the American public. The immigrant press, the preferred source of information for diverse ethnic groups, posed as an obstacle to the homogenization of public opinion. Rather than suppress the immigrant press, the CPI's liberal approach toward Americanization led them to seek out cooperation. Björkman's press office itself was staffed with Scandinavian-American newspapermen tasked with translating and creating pro-American propaganda material tailored for Scandinavian-American audiences, whether it be through quotations from ethnic leaders or showing the sacrifice of Sweden's sons for the American cause.

Edwin Björkman's work among Swedish Americans with his Scandinavian Bureau sought collaboration with the Swedish-American press and other major cultural institutions, such as the Augustana Synod. This cooperation sometimes required the coercive issuing of permits to

\footnotetext{
${ }^{279}$ P. O. Bersell to Edwin Björkman, June 11, 1918, entry 105, box 4-5, CPI.

${ }^{280}$ Edwin Björkman to Carl Byoir, June 12, 1918, entry 105, box 4-5, CPI.
} 
publish without having to file translations under the Trading with the Enemy Act. Björkman also took steps to control the flow of information coming in from Scandinavia, attempting to get newspapers first in order to provide a "correct" interpretation of events abroad and counter German propaganda before it arrived on American shores. To ensure that the press conveyed a wholly American message, Björkman used his censorship powers over the Swedish-American press to reward loyalty, patriotism, and cooperation with his Bureau and twist the arms of less cooperative papers to change their tone. In the case of the Augustana Synod, a vitally important and influential Swedish-American institution, Björkman used such powers in response to a scandalous article with the explicit purpose of spurring more intense patriotic activity among them, resulting in them falling more closely in line with his Bureau.

Just as with the John Ericsson League of Patriotic Service, Björkman used his position in the CPI to consolidate existing Swedish-American institutions and media under the umbrella of his Scandinavian Bureau. This process is indicative of the CPI's liberal Americanization and belief in cultural pluralism. Rather than demand that Swedish-Americans abandon their cultural heritage and ethnic ties, Björkman conducted his work through Swedish-American institutions, using their own language, leaders, organizations, and media sources. Though it sometimes required a bit of force, his work successfully directed Swedish-American efforts toward an overtly patriotic direction, homogenizing activities and messages across the United States.

Björkman's press work reveals the transnational linkages tying Swedish Americans to their homeland. Björkman saw Swedish news coming from abroad as threatening to SwedishAmerican political identification, revealing a degree of attachment to the Old Country. Björkman did not intend to deconstruct Swedish cultural identity in the United States but rather aimed to root out political allegiance to Sweden which often implied the pro-German stance of the 
Swedish upper classes. The Bureau's press work also had a transnational significance in the opposite direction. Depictions of Swedish-American patriotism and loyalty in the SwedishAmerican press similarly made its way back to Sweden. For this reason, Björkman wanted to flood the press with CPI material, correct pro-German stances coming in from abroad, and coerce papers into publishing such content through the permit system.

Björkman's press office did not only try to influence Scandinavia indirectly through the Swedish-American press, but also by distributing media in Scandinavia itself. The news stories prepared in Björkman's office were written with an eye for publication in the Scandinavian press as well. Björkman hired two men, Eric H. Palmer in April 1918 and Edward V. Riis in June, to open CPI press offices in Stockholm and Copenhagen, respectively. At the end of June, with the JELPS organized across the nation planning the Fourth of July festivities, the Swedish-American press under control, and the Augustana Synod in close cooperation, Björkman wrote in a memorandum to Ernest Poole, co-director of the CPI Foreign Press Bureau, about the state of his work. He predicted that although the Scandinavian Bureau "was organized almost exclusively with an eye to work among the Scandinavian population and press of this country," as the domestic situation became "more normal," he expected the Bureau's foreign work to "assume preponderance." ${ }^{281}$ In the following months, as American troops made gains against the Germans in France, the Scandinavian Bureau's efforts abroad did indeed come into greater focus.

${ }^{281}$ Edwin Björkman, “Memorandum for Mr. Poole,” entry 105, box 4-5, CPI. 


\section{CHAPTER IX: THE SCANDINAVIAN BUREAU ABROAD}

The Committee on Public Information's propaganda work in Scandinavia has received limited treatment by historians. James R. Mock and Cedric Larson discuss the CPI's operations in Sweden, Denmark, and Norway, mentioning briefly the men involved, the legitimate conduct of their work, the content of the propaganda, and their overall success. ${ }^{282}$ Other historians have explored the Committee's work in other foreign nations, such as Gregg Wolper, Louis John Nigro, Jr., and Daniela Rossini. ${ }^{283}$ Rossini's study of the CPI in Italy comes the closest to revealing the relationship between immigrant transnationalism and the CPI's foreign work. In her first chapter, she argues that Italian-American letters to friends and relatives back in Italy created the "myth of America" and spread American ideals, which ultimately formed a foundation for the CPI's propaganda. ${ }^{284}$ She also discussed the employment of the ItalianAmerican Captain Fiorella Guardia as a CPI agent in Italy. ${ }^{285}$ The focus of Rossini's study was on the work in Italy, and therefore a link between the domestic work among Italian Americans and the foreign work was absent.

From the beginning of Edwin Björkman's efforts to organize Swedish-Americans along patriotic lines, he aimed to strengthen the relationship between the United States and Sweden. Swedish-American immigrants stood at the forefront of this process as agents and subjects of propaganda. Before delving into a discussion of the content of the Committee on Public Information's foreign propaganda in Sweden, this chapter will provide important context for the foundations of American propaganda laid by Edward B. Robinette, the establishment of the

\footnotetext{
${ }^{282}$ Mock and Larson, Words That Won the War, 279-82.

${ }^{283}$ Wolper, "The Origins of Public Diplomacy;" Louis John Nigro, Jr., The New Diplomacy in Italy: American Propaganda and U.S.-Italian Relations, 1917-1919 (New York: Peter Lang, 1999); Rossini, Woodrow Wilson and the American Myth in Italy.

${ }^{284}$ Rossini, Woodrow Wilson and the American Myth in Italy, 25-29.

${ }^{285}$ Rossini, Woodrow Wilson and the American Myth in Italy, 106-11.
} 
Scandinavian Bureau's Stockholm office led by Eric H. Palmer, the nature of his operations, and the difficulties the Bureau encountered in the face of a German media monopoly and a hostile Swedish press. The ability of the Scandinavian Bureau to effectively disseminate its propaganda was a result of its cautious yet open approach to their work, their cooperation with pro-Allied elements within Sweden, and favorable events that turned the tide of the war against Germany.

American propaganda work in Scandinavia during the First World War began as it did in many other countries: through Military and Naval Intelligence and other diplomatic officials. ${ }^{286}$ Lieutenant Edward Burton Robinette, Assistant Naval Attaché in Stockholm, was the first head of American propaganda in Scandinavia. As early as December 1917 he was in communication with George Creel about the possibilities of expanding American propaganda to Sweden.

Defining moments of the war in March 1918 caused Robinette to place an even greater emphasis on the need of American propaganda in Sweden. The signing of the Brest-Litovsk Treaty between Germany and Russia in March ceded the Baltic provinces to the Kaiser. Shortly afterward, Germany intervened in the Finnish Civil War and occupied the Aaland Islands, home to a sizeable Swedish population and formerly occupied by the Swedish military. ${ }^{287}$ This occupation further cemented German hegemony over the Baltic Sea, effectively making it a "German lake." Furthermore, the treaty with Russia ended the war in the east, allowing Germany to concentrate its forces on the western front in the Spring Offensive, which made a German

\footnotetext{
${ }^{286}$ For more on the tension between American diplomatic officials and the CPI, see Wolper, "The Origins of Public Diplomacy: Woodrow Wilson, George Creel, and the Committee on Public Information."

${ }^{287}$ In the Brest-Litovsk talks Finland was to become an independent nation. A civil war broke out between the conservative Whites and socialist Reds over the nation's future. The Whites looked to both Sweden and Germany for support. When Russian soldiers committed atrocities against the population of Aaland - an archipelago in the Baltic Sea between Finland and Sweden within a minority Swedish population - the Swedish government sent soldiers primarily for humanitarian purposes, but also likely with the goal of annexation in mind. The Finnish Whites then requested that Germany occupy the islands and Sweden surrendered control. See Salmon, Scandinavia and the Great Powers, 162-67.
} 


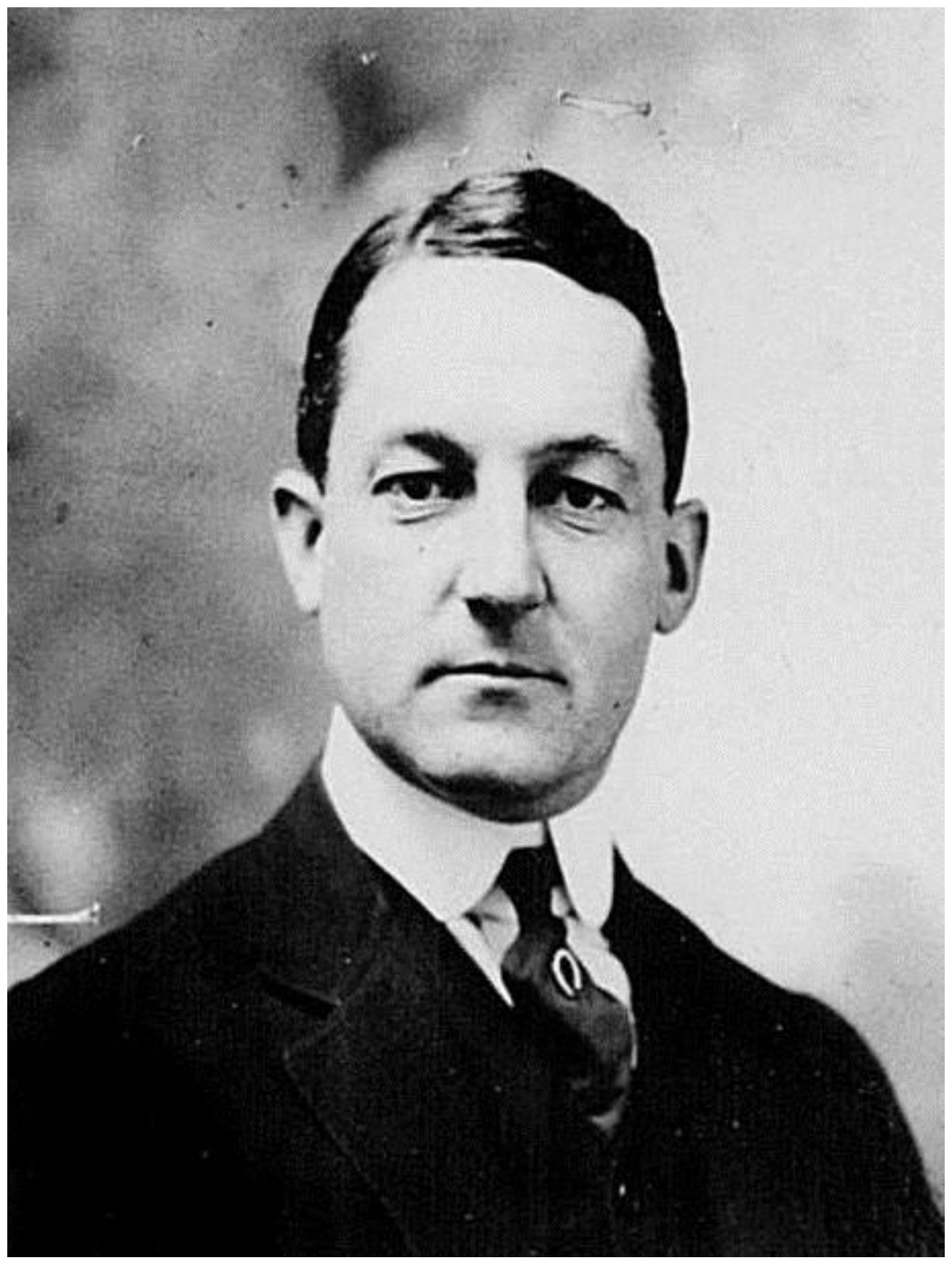

Figure 8: Lt. Edward B. Robinette, 1914. Courtesy of "United States Passport Applications, 1795-1925," FamilySearch, M1490, Passport Applications, January 2, 1906 - March 31, 1925, roll 227, 1914 Nov-Dec, certificate no 44334-45100, image 197; citing NARA microfilm publications M1490 and M1372. 
victory seem evermore likely. This rapid series of events over the course of a single month caused a heightened fear of a German invasion of Scandinavia, and American officials were anxious that Sweden might be compelled to join Germany as a result. ${ }^{288}$

Robinette saw such fear of Germany as an opportunity for the United States, believing that Scandinavians were "especially receptive at the present moment to Allied influence." 289

Robinette went further to explain the unique potential the United States had for propaganda due to its high levels of Scandinavian immigration:

America has greater opportunity of influencing Scandinavian opinion than all the other Allies, for the reason that there are so many Scandinavians in America...There are very few families, especially in the provinces of these three countries, who do not have relatives in America; they are anxious naturally to have news from America...Yet, up to this time, America has attempted in no way to use the great power which she has in her control to influence these people. ${ }^{290}$

Robinette's primary goal was to challenge the German press monopoly in Scandinavia, primarily Sweden, an effort which sought to restructure the existing system of global communications. Until 1918, news services of the Allied nations - including the British Reuters, French Havas, and American Associated Press—-sent their stories to the Wolffs Telegraphisches Bureau (Wolff Telegraphic Bureau) in Berlin to be transferred through the Ritzhau's Bureau in Copenhagen to the office of the Svenska Telegrambyrån (Swedish Telegram Bureau, SvT) in Malmö, Sweden. With Allied news being processed first through Germany, the Germans were able to select which stories would be sent to the Scandinavian press, giving them tremendous influence over public opinion. ${ }^{291}$ Robinette was the leading figure behind the creation of the Ally-backed Swedish telegram bureau, Nordiska Presscentralen (Nordic Press Center, NPC),

\footnotetext{
${ }^{288}$ Edward B. Robinette, "Memorandum of Propaganda in Scandinavia," March 26, 1918, entry 110, box 7, CPI.

${ }^{289}$ Edward B. Robinette, "Memorandum of Propaganda in Scandinavia," March 26, 1918, entry 110, box 7, CPI.

${ }^{290}$ Edward B. Robinette, "Memorandum of Propaganda in Scandinavia," March 26, 1918, entry 110, box 7, CPI.

291 “A War Gain,” The Forum, May 25, 1918, entry 110, box 7, CPI.
} 
which challenged the German monopoly on news in Scandinavia and allowed Swedes to receive unbiased Allied news directly from the source. Robinette believed that Germany's grip over Scandinavia stemmed from their control over the press and public opinion; the establishment of the NPC loosened this grip and opened the door to greater Allied influence. ${ }^{292}$

While arranging the creation of the NPC, Robinette also provided general assessments of the propaganda situation in Scandinavia as well as a detailed description of how the United States should proceed with disseminating its own propaganda. In addition to having great influence over the Scandinavian press, the Germans also held a near monopoly of pictures and film. In July 1918, a report stated that "the Germans have had practically a monopoly of picture propaganda in Denmark and Sweden" through the employment of "a score or more of men to tour the country and attend to their pictorial displays" in bookshops and storefronts as well as newspapers and magazines where they would be widely seen by the public. ${ }^{293}$ Regarding films, Robinette explained how “companies here [in Sweden] are being compelled to buy in Germany and accept their propaganda films," due to the simple fact that there were no alternatives available. ${ }^{294}$ Just as they had bought up the press, Creel revealed how German agents "had bought up practically all the moving picture houses in some of the neutral countries," and that "they thought nothing of paying $\$ 25,000$ for a hole-in-the-wall picture house." ${ }^{295}$ It was the goal of Germany's large propaganda apparatus, in Creel's words, to “convince foreign peoples of her military power and her overwhelming pre-eminence in industry, commerce, science, and the

\footnotetext{
${ }^{292}$ Edward B. Robinette, "Memorandum of Propaganda in Scandinavia," entry 110, box 7, CPI. Robinette received a Navy Cross for his work in establishing the NPC during the war. See: The Hall of Valor "Edward B. Robinette," Sightline Media Group, 2021, accessed February 11, 2021, https://valor.militarytimes.com/hero/9990.

${ }^{293}$ Eric H. Palmer, "Memorandum for Foreign News Bureau, Committee on Public Information," July 31, 1918, entry 106 , box 16 , CPI.

${ }^{294}$ Ira Nelson Morris to Secretary of State, 18 December 1917, file 103.9302/7, CDF.

${ }^{295}$ United States Committee on Public Information and George Creel, The Creel Report, 7; Creel, Rebel at Large, 166.
} 
arts."296 Through such propaganda, Germany hoped to secure other nations within their sphere of influence in the post-war world.

Robinette firmly believed that there was a strong desire for American news, pictures, and film in Scandinavia, and therefore the United States needed to break the German monopoly and make their media available. American media could then serve the public diplomatic purpose of convincing Scandinavian populations of the United States' own preeminence in commerce, industry, science, technology, and culture with the intention of strengthening America's commercial and diplomatic relationship with the region.

Robinette's proposal for how the United States should go about this task mirrored many of the German agents' methods: buying up the press, monopolizing the film industry, disseminating photographs, helping native Scandinavians sympathetic to their cause, providing unlimited funding, and conducting all work in secret. ${ }^{297}$ While Edwin Björkman came to reject many of the more unscrupulous practices of buying up the press and conducting work in secrecy, Robinette's general assessments of the propaganda situation in Scandinavia revealed the demand and necessity of American propaganda in Scandinavia to challenge the German media monopoly and expand the United States' sphere of influence in the postwar world. ${ }^{298}$

Like Robinette, Björkman was also anxious to send American representatives abroad in February and March 1918. Due to German advances in Russia and Finland, Björkman believed that "the pressure on Sweden to come into the war on the German side will be greater during the next few months than it has ever been during the war." ${ }^{299}$ At first, he wanted to send a small delegation of Swedish-American labor representatives to major Swedish cities to meet with

\footnotetext{
${ }^{296}$ Creel, Rebel at Large, 166.

${ }^{297}$ Edward B. Robinette, "Memorandum of Propaganda in Scandinavia," March 26, 1918, entry 110, box 7, CPI.

298 This tension between the American diplomatic officials and the CPI regarding the conduct of propaganda abroad was common, see Wolper, "The Origins of Public Diplomacy."

${ }^{299}$ Edwin Björkman to John Walquist, February 21, 1918, entry 105, box 4-5, CPI.
} 
Liberal and Socialist leaders such as Hjalmar Branting, Nils Eden, and Herman Lindkvist. This delegation, led by Minneapolis Alderman John Walquist, was to reassure these leaders that the United States was rapidly arming, that American organized labor stood behind the administration in their fight for democracy, and that they would stop at nothing to defeat Germany. ${ }^{300}$ Such a message intended to dissuade Swedish leaders from considering joining the war on the side of Germany despite their fears of invasion—rest assured, the United States would defeat Germany. Despite the approval of the trip by George Creel, it appears that the plans were scrapped in favor of sending a representative of the CPI's Scandinavian Bureau to open an American press office.

Robinette was the natural choice to conduct CPI propaganda work in Stockholm. In early March, H. N. Rickey, at this time the CPI commissioner in London, wrote Creel that he was arranging for Robinette "to head our Scandinavian Bureau," regarding him as the "best man available to take charge [in] Scandinavia" due to his several months of experience assessing the propaganda situation in the region. ${ }^{301}$ Robinette's placement at the head of the Bureau's foreign office was, however, met with significant pushback from not only Creel, but Secretary of the Navy Josephus Daniels and President Wilson. Creel responded to Rickey that "both [the] president and Secretary Daniels are absolutely opposed to [the] use of army or navy or diplomatic representatives as directors of open propaganda work." ${ }^{302}$ Although American foreign officials frequently assisted the CPI, having them openly perform propaganda work would undermine their positions as diplomatic or military officials. It was therefore necessary for the

\footnotetext{
${ }^{300}$ Edwin Björkman to John Walquist, February 21, 1918, entry 105, box 4-5, CPI.

${ }^{301}$ Ira Nelson Morris to Polk, February 26, 1918, file 103.93/58, CDF; H. N. Rickey to George Creel, March 18, 1918, file 103.93/83, CDF.

${ }^{302}$ Creel to Rickey, March 22, 1918, entry 106, box 18, CPI.
} 
CPI to employ a civilian for the position. The ideal candidate was, in Creel's words, the "highest type of Swedish American newspaper man." ${ }^{303}$

Björkman took on the task of seeking out a man to head the Scandinavian Bureau's Stockholm office. His first choice was renowned Norwegian-American newspaperman and diplomat Nicolay Andreas Grevstad. During the war, Grevstad was employed by the Minnesota Commission of Public Safety (MCPS), taking on a task rather similar to that of the Scandinavian Bureau: monitoring the Scandinavian-American press for disloyalty and encouraging patriotic activity. ${ }^{304}$ Björkman planned for Grevstad to arrive in Stockholm in early April 1918, however he withdrew at the last minute, most likely to continue his work for the MCPS. ${ }^{305}$ After further investigation and an interview, Björkman decided that Eric H. Palmer would be sent in his place.

Eric Harald Palmer, a newspaperman from Brooklyn, New York, was born in Malexander, Sweden in 1887 and came to the United States with his parents at the age of six. Palmer was educated in the United States, though he was fluent in Swedish, and married an American woman with whom he had two children. He worked as a journalist for twelve years before becoming the secretary to the Borough President of Brooklyn, and later became an executive with the Todd Shipyards Corporation. Björkman decided after meeting with him in early April that he was "the best man we have had in sight for the job so far." 306 Upon approval by Will Irwin, Björkman made reservations for Palmer to sail to Scandinavia on the Hellig Olav on April 10.

\footnotetext{
${ }^{303}$ George Creel to H. N. Rickey, March 7, 1918, entry 159, box 1, CPI.

${ }^{304}$ Chrislock, Ethnicity Challenged, 70.

305 George Creel to H. N. Rickey, March 22, 1918, entry 106, box 18, CPI; Will Irwin to Edgar Sisson, April 5, 1918, file 103.93/147e, CDF.

${ }^{306}$ Edwin Björkman to Will Irwin, April 3, 1918, entry 105, box 4-5, CPI.
} 
Upon his arrival, Palmer stated how he would be "Proceeding as Attache of the Legation here [in Stockholm,] Christiania and Copenhagen," ${ }^{307}$ mistaking his role in the CPI as a diplomatic position. Palmer was quickly corrected by Irwin that "this work is in no way formally to be connected with the Army, the Navy or the State Department. ... Work in harmony with [the] Legation and its attaches, but maintain separate existence." ${ }^{\prime 308}$ To begin his work, Palmer was approved $\$ 20,000$ with the "understanding that none of it shall be spent for bribing officials, secretly influencing the press, buying news space in newspapers or in any other way that would convey the slightest impression that the Government is using ulterior methods." ${ }^{\prime 309}$ The precedent was set immediately that unlike the agents employed by Germany, Palmer would be conducting his press work using fully legitimate means.

\section{Palmer's Stockholm Office}

Due to the high cost of office spaces in Stockholm, Palmer had difficulty finding a place for the Scandinavian Bureau's press office. In mid-May, Palmer opened a temporary office in an apartment large enough to have both a "working room" and space "for the reception of people which whom I have to come in contact." ${ }^{310}$ Later in August, through the help of some English contacts, Palmer secured an office located "in one of the most desirable spots in Stockholm," No. 19 Birger Jarlsgatan. ${ }^{311}$

After settling into his first office, Palmer received a letter from Björkman outlining his vision and "definite instructions" for American propaganda in Scandinavia. ${ }^{312}$ In contrast to Robinette's recommendations, Palmer's office would not operate as one would expect a

\footnotetext{
${ }^{307}$ Eric H. Palmer to CPI, May 1, 1918, file 103.93/213, CDF.

${ }^{308}$ Will Irwin to Eric H. Palmer, May 7, 1918, file 103.93/261e, CDF.

${ }^{309}$ Will Irwin to Eric H. Palmer, May 15, 1918, file 103.93/312k, CDF.

${ }^{310}$ Eric H. Palmer to Edwin Björkman, July 22, 1918, entry 106, box 16-17, CPI.

${ }^{311}$ Eric H. Palmer to Edgar Sisson, August 21, 1918, entry 106, box 16-17, CPI.

${ }^{312}$ Edwin Björkman to Eric H. Palmer, June 15, 1918, 3070, folder 19, Edwin Björkman Papers.
} 


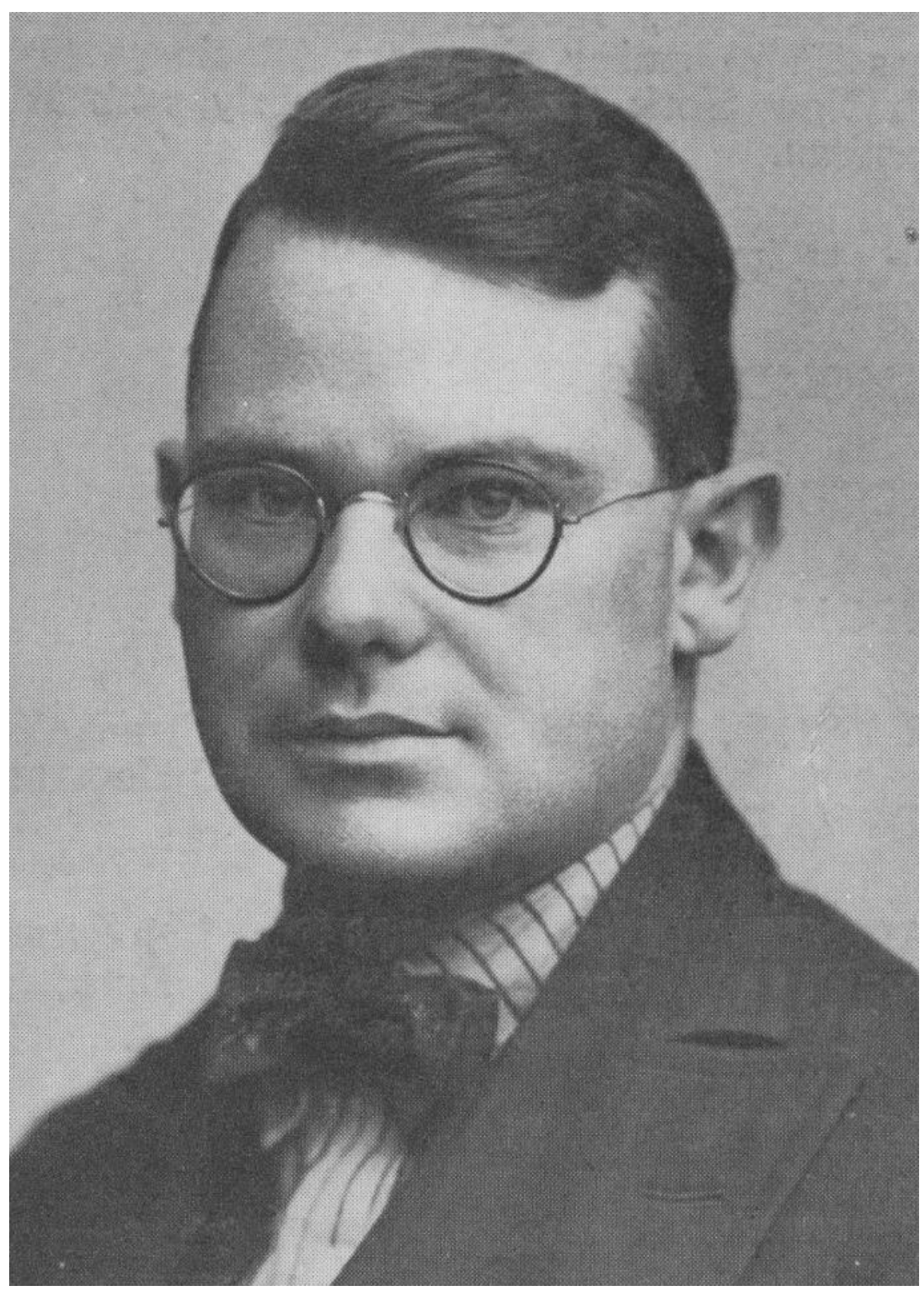

Figure 9: Eric H. Palmer. Reproduced from Brooklyn Press Club: About Ourselves, By Ourselves, 1912-1922, ed. by the Brooklyn Press Club (Brooklyn: Brooklyn Press Club, 1922), 11. 
propaganda organization to, that is in secret using methods of questionable ethics. Björkman believed that "we cannot compete with the Germans in unscrupulousness or mendacity," and that such methods would inevitably alienate Scandinavians from their message. On the contrary, Björkman told Palmer that he should conduct his work openly, presenting himself as "an ordinary news agency." On the doorplate of his office, he should state his name and business, "Representative of the American Committee on Public Information," and "let whoever it may concern know that you have come to Sweden on behalf of the American Committee on Public Information for the double purpose of obtaining and disseminating information of entirely legitimate kind." If Palmer's presence was questioned or objected to, he should state that his work has "nothing to do with spying of any kind" and "little to do with what is generally termed propaganda." It should be his position that the war was a product of the "mutual ignorance that lies like an unbridgeable chasm between nation and nation" and the CPI served to bridge this chasm. His presence served to create "a better understanding of Sweden in America and of America in Sweden." ${ }^{313}$

Regarding the content of his press material, Björkman told Palmer that it should not be blatant propaganda but "straight news, in a word, tending merely to bring before the Swedish people a correct image of what this country is saying and doing, wishing and willing." Palmer should not "act as a drummer talking for his wares," but "merely hold it at the disposal of whosoever may be anxious for enlightenment." He should hire an office staff to translate and produce material for the Swedish press, all fully prepared and edited by himself before distribution. Palmer should then decide "systematically and scientifically" where to place each item: whether it should be sent to a single publication or distributed widely, "whether it is likely

${ }^{313}$ Edwin Björkman to Eric H. Palmer, June 15, 1918, 3070, folder 19, Edwin Björkman Papers. 
to appeal to Socialists or Conservatives, to shoemakers or engineers, to the earnest or the frivolous." 314

Having acquired office space and instructions from Björkman, Palmer began his press work. His office staff was composed of native born Swedes including Dr. Kjell Stromberg as translator and at one time three young women as stenographers. ${ }^{315}$ The office functioned much like Björkman's back in New York. His staff translated material sent to him by the CPI's Foreign Press Bureau and Wireless-Cable Service as well as produced its own material tailored specifically for the separate Scandinavian populations. To produce this information, Palmer requested various information and statistics from Björkman, who then forwarded it onto him. Björkman's office supplied Palmer with his office's written and translated material. In two separate reports, Björkman wrote that all material produced in his office for the domestic service was also sent abroad. ${ }^{316}$ In addition to press work, Palmer cooperated with the Scandinavian Bureau's film representative, Guy Crosswell Smith, for the distribution of American picture propaganda in the press and in public window displays. ${ }^{317}$ Smith conducted his successful film campaign in Scandinavia independently from Palmer, having his own office and staff. ${ }^{318}$

Palmer encountered great hostility from the pro-German press in Sweden, who regarded his as "an unwelcome news service." 319 American propaganda representatives mentioned the Swedish people as having a great fear of foreign propagandists. Sweden was neutral in the war and maintaining the appearance of a neutral press was important to avoid undermining its

\footnotetext{
${ }^{314}$ Edwin Björkman to Eric H. Palmer, June 15, 1918, 3070, folder 19, Edwin Björkman Papers.

${ }^{315}$ Eric H. Palmer to George Creel, May 27, 1919, entry 106, box 16-17, CPI; Edward V. Riis to Edgar Sisson, August 8, 1918, entry 106, box 16-17, CPI.

${ }^{316}$ Edwin Björkman, "Report on the work of the Scandinavian Bureau, from October 31 to November 26," entry 105, box 4-5, CPI; Edwin Björkman, "Report on the work of the Scandinavian Bureau, from November 27 to December 27, 1918," entry 105, box 4-5, CPI.

${ }^{317}$ Eric H. Palmer to George Creel, June 17, 1918, entry 106, box 16, CPI.

${ }^{318}$ Guy Crosswell Smith to Sisson, September 14, 1918, entry 108, box 6, CPI.

${ }^{319}$ Eric H. Palmer, "Memorandum for Foreign News Bureau, Committee on Public Information," entry 106, box 1617 , CPI.
} 
neutrality and provoking the belligerents. This being said, conservative Swedish papers were inclined toward pro-German sympathies, German banks financially supported some papers, and German agents bought space in others. For example, Björkman believed that the Stockholm paper Aftonbladet was "not a pro-German paper. I regard it as much a German paper as the 'Berliner Tageblatt'," in that it was directly funded by Germans and its staff were "hopelessly" pro-German if not also on the payroll of the German government. ${ }^{320}$ Furthermore, given that Swedish papers were accustomed to frequent stories from Berlin and few from Allied nations, the greater presence of unbiased Entente news might appear as a systematic propaganda campaign on their part. For this reason, Palmer worked slowly and cautiously, being careful not to provoke the pro-German Swedish press. ${ }^{321}$

Despite this hostility, Palmer formed relationships with urban and provincial editors to gain their trust and facilitate the distribution of American news. In a letter to friends back in Brooklyn, Palmer wrote about how he kept himself busy attending luncheons, dinners, and suppers to network and befriend local newspapermen. One notable meeting was that of the Publicists Club, "the chief journalistic tribunal of Sweden," which Palmer regarded as important to "increase my friendly relations with the press." 322 The "stiffness and formality" of the Swedes took some getting used to for Palmer. He expressed that "this business of taking off your hat when you meet a man and bowing all over the place gets the American's 'goat;' but it does not take long to get acclimated." 323 Though some found his "breezy" American attitude a bit off-

\footnotetext{
${ }^{320}$ Edwin Björkman to Edgar Sisson, September 11, 1918, entry 105, box 4-5, CPI.

${ }^{321}$ Eric H. Palmer to Edwin Björkman, July 22, 1918, entry 106, box 16-17, CPI; Eric H. Palmer, "Memorandum for Foreign News Bureau, Committee on Public Information,” entry 106, box 16-17, CPI.

${ }^{322}$ Eric H. Palmer to Will Irwin, June 13, 1918, entry 106, box 16-17, CPI.

${ }^{323}$ Proof of article "Palmer Describes Life in Sweden," enclosed with Joseph J. Early to George Creel, September 20, 1918, entry 106, box 16-17, CPI.
} 
putting, Palmer got along well with the Swedes. ${ }^{324}$ To further aid his efforts, he also requested scarce luxuries from the United States such as cigars, cigarettes, coffee, and tea to treat guests at his office. $^{325}$

By mid-June 1918, Palmer told Björkman that there was a slow realization that his work was "an honorable effort to promote a mutual better understanding between nations which should possess for each other the most friendly feeling." ${ }^{326}$ Affirming Robinette's prediction of the usefulness of immigrants' transnational ties, Palmer noted that the editors accepted his Bureau "especially in view of the fact that so many Swedes are living in the United States." 327 By this time, Palmer wrote that Swedish newspapermen were "calling me up every day" for the most recent American news. ${ }^{328}$

Palmer found particularly strong allies among Swedish Liberals and Socialists. A coalition of Liberals and Socialists had recently come to control the Swedish Parliament following the September 1917 elections. Their coalition represented the bulk of the Swedish working class and pushed for democratic reform in Sweden. Though their war policy was one of true neutrality rather than one of tacit support for Germany, their support for democracy made them sympathetic to the Allied cause. Björkman indicated in a June memorandum that Robinette's Swedish telegram bureau, NPC, had "the support of the entire Socialist press and more of the Liberal papers" in its mission to disseminate unbiased Entente news. ${ }^{329}$ In June Palmer had corresponded with the leader of the Swedish Social Democrats, Hjalmar Branting,

\footnotetext{
${ }^{324}$ Edwin Björkman to Eric H. Palmer, July 30, 1918, entry 106, box 16-17, CPI; Edwin Björkman to Edgar Sisson, August 13, 1918, entry 105, box 4-5, CPI.

${ }^{325} \mathrm{Mr}$. Atwater to H. N. Rickey, December 12, 1918, entry 106, box 16-17, CPI.

${ }^{326}$ Eric H. Palmer to Edwin Björkman, July 22, 1918, entry 106, box 16-17, CPI.

${ }^{327}$ Eric H. Palmer to Edwin Björkman, July 22, 1918, entry 106, box 16-17, CPI.

${ }^{328}$ Eric H. Palmer to Will Irwin, June 13, 1918, entry 110, box 7, CPI.

${ }^{329}$ Edwin Björkman, "Memorandum on the Political Situation in the Scandinavian Countries," entry 110, box 7 , CPI.
} 
whom he said was "ready to help me wherever he can and that counts for a great deal." $330 \mathrm{He}$ also worked to develop a system of educational exchange with the Minister for Education Värner Rydén, also a Social Democrat. ${ }^{331}$

Though he formed relationships with Swedish journalists eager to publish American news - due either to popular demand or pro-Allied sympathies - the general hostility of the proGerman press persisted. On August 8, Palmer wrote Björkman explaining that "journalists who are friendly to us have a difficult task getting their articles printed. As a result of their belief in the Allies, they have lost many sources of income. ... our friends are the ones who are suffering just now."332

It was on that same day, August 8, that the Allied Hundred Day Offensive began with the Battle of Amiens, followed by a succession of victories quickly pushing back the Germans beyond the Hindenburg Line. As a result of successful Allied offensives, the environment changed within Scandinavia. On August 13, Björkman wrote how "there has undoubtedly been a pretty radical change over there, and things are beginning to turn our way. Continuous success on the western front will help us tremendously." 333 As the tide of the war turned and a German victory seemed less inevitable, there grew a greater interest in and openness to American news. Additionally, successive military defeats rendered the Germans less able to support their rigorous propaganda campaign in Scandinavia. In November, Guy Crosswell Smith, the Scandinavian Bureau's film representative, wrote to Edgar Sisson that he was unable to secure German

\footnotetext{
${ }^{330}$ Eric H. Palmer to Will Irwin, June 13, 1918, entry 110, box 7, CPI.

${ }^{331}$ Eric H. Palmer to Edgar Sisson, October 19, 1918, entry 106, box 16-17, CPI.

332 Eric H. Palmer to Edwin Björkman, August 8, 1918, entry 105, box 4-5, CPI.

${ }^{333}$ Edwin Björkman to Edgar Sisson, August 13, 1918, entry 105, box 4-5, CPI.
} 
propaganda films for analysis back in the United States because German "government film offices have been closed for two months owing to the difficult conditions." 334

In the face of a German media monopoly and a hostile, pro-German Swedish press, Eric H. Palmer successfully established an American press office in Stockholm to distribute American propaganda in Sweden. Having been warned by Björkman, Palmer conducted his work openly and cautiously to avoid being branded a belligerent propagandist. He successfully communicated to sympathetic Swedish editors that his message was one of straight, unbiased news merely serving the mutually beneficial purpose of creating understanding between the United States and Sweden. Diligent networking, cooperation with pro-Allied Liberals and Socialists within Sweden, and the rollback of the German army all facilitated the success of his propagandizing efforts. Another significant factor for the eager Swedish consumption of Palmer's press material was its content, a significant portion of which dealt specifically with the lives and activities of Swedish Americans.

${ }^{334}$ Guy Crosswell Smith to Edgar Sisson, November 18, 1918, entry 108, box 6, CPI. 


\section{CHAPTER X: CONTENT OF THE BUREAU'S FOREIGN PROPAGANDA}

The public diplomatic purpose of the Committee on Public Information was to endear foreign populations to the United States as to facilitate a closer relationship and cooperation between the nations - be it political, commercial, or social. Up until the establishment of the CPI's press office in Stockholm, Scandinavians were largely ignorant of life in the United States. Palmer wrote in a letter to friends in Brooklyn how "it is remarkable how little the people of Scandinavia know about modern America. The process of education must begin along the elementary lines. There is now a lack of mutual understanding, and the principles of American politics, as well as American life and characteristics, are practically unknown here." 335 The little news that did make it abroad, to quote George Creel, "dealt almost entirely with the violent and unusual in our national life: strikes, graft scandals, sensational divorce suits, murders and riots, lynchings, and the bizarre extravagances of the newly rich and addlepated heirs to huge fortunes." ${ }^{336}$ Palmer made a similar statement in his final report regarding Swedish news, concluding that "it is not strange that misconceptions of American affairs had been formed, not the least of which was that the United States was essentially a 'dollar country,"' obsessed with wealth and materialism. ${ }^{337}$ Palmer thus regarded his mission as an educational one-surely if Scandinavians knew the truth about the United States the nations would move toward a closer relationship.

The purpose of American propaganda in Scandinavia was not to outright attack Germany, as Swedes were anxious to protect their neutrality and were hostile of open propaganda work. Instead, the objective of the Scandinavian Bureau was to correct misrepresentations and

\footnotetext{
335 Proof of article "Palmer Describes Life in Sweden," enclosed with Joseph J. Early to George Creel, September 20, 1918, entry 106, box 16-17, CPI.

${ }^{336}$ Creel, Rebel at Large, 166.

${ }^{337}$ Eric H. Palmer to George Creel, May 27, 1919, entry 106, box 16, CPI.
} 
misunderstandings regarding the United States. Palmer requested that the material forwarded to him from Washington "should not denounce German activities but simply describe American activities. It will be sufficiently impressive to have statements of what America is doing."338 The content of the Scandinavian Bureau's propaganda in Scandinavia can be broken up into two broad categories: general propaganda material and Scandinavian-American material. General propaganda served the purpose of informing Scandinavians about America's leaders, government, institutions, industry, technological innovations, people, culture, natural landscapes, etc. Scandinavians were interested in such topics due to America's growing presence on the world stage, their increasingly leading role in the war, their technological progress, being a model democratic nation, and President Wilson's vision for the post-war world among other things. Such propaganda also served the public diplomatic purpose of strengthening the social, political, and commercial relationships between the United States and Sweden as a result of widespread positive publicity.

CPI scholars James R. Mock and Cedric Larson noted the Bureau's employment of Scandinavian-American propaganda abroad, pointing out that Björkman's domestic activities as well as "the numerous contacts between Sweden and America" facilitated such work. ${ }^{339}$ To expand on this notion of the significance of the "numerous contacts" between the United States and Sweden, the Scandinavian Bureau's Scandinavian-American propaganda was rooted in the transnational ties maintained between immigrants and their friends and relatives in the Old Country. Elements of the Scandinavian population, particularly those in the rural provinces, had a unique interest in learning more about America due to their personal relationships with immigrants. This natural interest in America proved uniquely effective in the Scandinavian

\footnotetext{
${ }^{338}$ Eric H. Palmer to Edgar Sisson, July 30, 1918, entry 106, box 16, CPI.

${ }^{339}$ Mock and Larson, Words That Won the War, 279.
} 
Bureau's objective of disseminating information about life in America and endearing Swedish populations to the United States.

\section{General Propaganda}

As stated above, the notion of attacking Germany was out of the question due to Swedish sensitivity towards more obvious forms of propaganda. Palmer therefore opted instead to "impress the [Scandinavian] press with America's strength and influence." ${ }^{340}$ Much like in the United States, the CPI wanted their propaganda to engage as many segments of the population as possible, and therefore needed to produce and procure material on diverse subjects. Through his own personal observations, conversations with locals, and requests from editors, Palmer discerned which material Scandinavians were lacking and what they might be interested in.

Information about the American government and military were of interest in Sweden during the war. Palmer wrote to Björkman requesting stories and photos about members of the Cabinet and new administrative departments. In an early letter to Will Irwin, Palmer stated that stories about William Gibbs McAdoo, Herbert Hoover, and others were "going big." ${ }^{341}$ In midSeptember after many American military successes in France, Palmer received "so many questions" regarding the United States marines, and therefore requested that the Foreign Press Bureau prepare a special story on their history, exploits, and commanders, accompanied by photographs. ${ }^{342}$ Palmer also noted in a report that stories about Secretary of the Navy Josephus Daniels and the American navy in general were popular in Scandinavia. ${ }^{343}$ Such stories provided details about the United States' democratic system, its leading men, and its military strength that turned the tide of the war on the western front.

\footnotetext{
${ }^{340}$ Eric H. Palmer to Edwin Björkman, August 8, 1918, entry 105, box 4-5, CPI.

${ }^{341}$ Eric H. Palmer to Will Irwin, June 13, 1918, entry 106, box 16, CPI.

342 Eric H. Palmer to Paul Kennaday, September 18, 1918, entry 106, box 16, CPI.

${ }^{343}$ Eric H. Palmer, "Memorandum for Foreign News Bureau, Committee on Public Information,” July 31, 1918, entry 106 , box 16 , CPI.
} 
A second topic of interest was industry and labor in the United States. Palmer prepared articles on shipbuilding, railroads, and airplanes, as Scandinavians were interested in American technological innovations, war preparations, and the conditions of the working class. In addition to workers, Palmer also noted a special interest in "new men of the industrial world" such as Henry Ford. ${ }^{344}$ Referring to both leaders in government and industry, Palmer bemoaned how Scandinavians knew "practically nothing about the new men of America;" they needed to be educated "on the changes which are taking place in America, not only in the personell of its leaders but regarding the methods which have been adopted to produce the results which are amazing the world." ${ }^{345}$ Further communicating that the future of progress laid with the United States, Palmer prepared feature articles for specialty magazines on topics such as agriculture, engineering, commerce, education, and medicine. ${ }^{346}$ Through this propaganda, Palmer could communicate America's industrial strength and its position at the forefront of technological innovation and progress.

In addition to America's democratic institutions and military and industrial strength, Palmer also wanted to educate Scandinavians about the vibrancy of American culture. Palmer observed that Scandinavians were "strong and healthy people" interested in athletics, and therefore requested pictures of America's greatest athletes. ${ }^{347} \mathrm{He}$ also "highly recommend[ed]" that American music be sent over and sold, in addition to photos and stories about "American opera singers, concert artists, dramatic stars, as well as the leading moving picture people." 348 The Stockholm office prepared material on American cities in wartime, such as Washington DC

\footnotetext{
${ }^{344}$ Eric H. Palmer, "Memorandum for Foreign News Bureau, Committee on Public Information,” July 31, 1918, entry 106 , box $16, \mathrm{CPI}$.

${ }^{345}$ Eric H. Palmer to Edwin Björkman, July 22, 1918, entry 106, box 16, CPI.

${ }^{346}$ Eric H. Palmer to Edgar G. Sisson, October 2, 1918, entry 106, box 16, CPI; Eric H. Palmer to George Creel, May 27, 1919, entry 106, box 16, CPI.

${ }^{347}$ Eric H. Palmer to Paul Kennaday, July 8, 1918, entry 106, box 16, CPI.

${ }^{348}$ Eric H. Palmer to Paul Kennaday, August 26, 1918, entry 106, box 16, CPI; Eric H. Palmer to George Creel, June 17, 1918, entry 106, box 16, CPI.
} 
and New York. ${ }^{349}$ It was the goal of CPI picture and film propaganda to depict the vastness and entirety of the United States, showing its national parks, rivers and lakes, factories, farms, cities, and people. ${ }^{350}$ For films in particular, Guy Crosswell Smith distributed features on a variety of topics, such as "war activity subjects, educational, industrial and social, and romantic dramas and comedies." Regarding the utility of drama films in addition to "educational" propaganda material, Edgar Sisson commented that they were important "to show every phase of American life." 351

The final and perhaps most significant feature of the Scandinavian Bureau's general propaganda was President Woodrow Wilson. The CPI made Wilson the visionary leader for postwar peace and democracy. CPI news stories often featured Wilson's statements, speeches, and image. Palmer distributed pamphlets presenting Wilson's vision of the postwar world articulated in his Fourteen Points and addresses regarding the League of Nations. As early as July 1918, Palmer referred to anything related to Wilson as "of course first class material." 352 The real demand for Wilson-related propaganda came near the end of the war in mid-October and after the armistice. By this time, Palmer wrote that Wilson was "daily given prominence in [the] Swedish press," and requested that his History of the American People be translated into Swedish. ${ }^{353} \mathrm{He}$ also began distributing 25,000 copies of the pamphlet "President Wilson and the League of Nations," a topic which Palmer noted "the Swedish people [were] becoming more and more interested." ${ }^{" 354}$ On November 11 following the signing of the armistice, Palmer requested

\footnotetext{
${ }^{349}$ Eric H. Palmer to Committee on Public Information, July 23, 1918, entry 106, box 16, CPI.

${ }^{350}$ Ira Nelson Morris to George Creel, March 16, 1918, file 103.93/79, box 732, CDF.

${ }^{351}$ Edgar Sisson to Will Irwin, April 9, 1918, file 103.93/141, box 732, CDF.

${ }^{352}$ Eric H. Palmer, "Memorandum for Foreign News Bureau, Committee on Public Information," July 31, 1918, entry 106, box 16, CPI.

${ }^{353}$ Eric H. Palmer to Edgar Sisson, October 18, 1918, entry 106, box 16, CPI; Eric H. Palmer to Edgar Sisson, October 25, 1918, entry 106, box 16, CPI.

${ }^{354}$ Eric H. Palmer to Edgar Sisson, October 19, 1918, entry 106, box 16, CPI; Eric H. Palmer to George Creel, May 27,1919 , entry 106 , box 16 , CPI.
} 
buttons and postcards bearing Wilson's image. ${ }^{355}$ In his January report, Björkman stated that the Fourteen Points "received wider publicity in the Scandinavian countries than that granted to any other document of the war." ${ }^{356}$ Lastly, in Palmer's final report, he claimed that he had supplied "several hundred" photos to Wilson to "his Swedish admirers." 357

This general propaganda material featuring America's democratic institutions, military and industrial might, technological innovations, progress, and culture were common in the CPI's propaganda across the globe. What was unique about the Scandinavian Bureau's propaganda abroad in particular was the "special phase" of their work noted by Mock and Larson: its usage of Scandinavian-Americans as subjects of propaganda. ${ }^{358}$

\section{Scandinavian-American Propaganda}

From the beginning of the American propaganda effort in Scandinavia, foreign representatives believed that Scandinavian immigrants provided a unique means to influence Scandinavian public opinion in favor of the United States. Edward Robinette's memorandum of March 1918 noted this potential "great power" possessed by the United States' to shape Scandinavian public opinion. ${ }^{359}$ Through Edwin Björkman's early work with the John Ericsson League of Patriotic Service, he told local council leaders to encourage their patriotically active membership to write letters to family and friends back in Sweden. ${ }^{360}$ Additionally, Björkman's work with the Swedish-American press facilitated the publishing of articles commenting on the loyalty and patriotism of Swedish-Americans, stories which would make their way back to Sweden. The opening of Eric Palmer's office in Sweden provided an opportunity to disseminate

\footnotetext{
355 Eric H. Palmer to Paul Kennaday, October 15, 1918, entry 106, box 16, CPI.

${ }^{356}$ Edwin Björkman, "Memorandum for Mr. Poole: Final Report from Mr. Edwin Björkman, Scandinavian Countries," January 10, 1919, entry 105, box 4-5, CPI.

${ }^{357}$ Eric H. Palmer to George Creel, May 27, 1919, entry 106, box 16, CPI.

${ }^{358}$ Mock and Larson, Words That Won the War, 279.

${ }^{359}$ Edward B. Robinette, "Memorandum of Propaganda in Scandinavia," March 26, 1918, entry 110, box 7, CPI.

${ }^{360}$ Edwin Björkman to George Creel, March 14, 1918, entry 105, box 4-5, CPI.
} 
articles about Swedish-Americans in the Swedish press more effectively, something which Palmer was well aware of given that he requested from Björkman news on the Scandinavian Bureau's activities "and all other Swedish American material."361

While Palmer experienced some hostility from the Stockholm press after opening his office, the first friendly contacts he made were with provincial newspapers interested in publishing news about Scandinavian Americans. Palmer stated in his final report that the "biased" character of the Stockholm press made his work difficult, but he nonetheless made early success among the "not so biased" provincial press. ${ }^{362}$ Earlier in August, Edward V. Riis, the Scandinavian Bureau's representative in Copenhagen, communicated a similar sentiment to Björkman that Palmer had managed to get little material published in any Stockholm papers, however "about fifty papers were taking his service" which were "mostly provincial." These papers avoided any material with "too clear an intimation of propaganda," and did not want long articles "unless they have to do with the activities of Swedes in America," among a couple other topics. ${ }^{363}$ Agricultural topics were popular among the provincial press, especially from regions populated by their countrymen. Two letters from Palmer state this demand for agricultural news, "particularly [from] Wisconsin, Minnesota and Illinois" where there were high rates of Scandinavian settlement, as well as details on victory gardens, "with special relation to New York and the Central West, where so many Scandinavians live."364

Palmer noted that the provincial press published the Scandinavian Bureau's series on “letters from America." In late February 1919, Palmer sent Björkman several clippings of articles featuring these newsletters. Commenting on their distribution, he explained how they had

\footnotetext{
${ }^{361}$ Eric H. Palmer to Committee on Public Information, May 4, 1918, file 103.93/231, box 732, CDF.

${ }^{362}$ Eric H. Palmer to George Creel, May 27, 1919, entry 106, box 16, CPI.

${ }^{363}$ Eric H. Palmer to Edgar Sisson, August 8, 1918, entry 106, box 16, CPI.

${ }^{364}$ Eric H. Palmer to George Creel, May 7, 1918, entry 110, box 4, CPI.
} 
"been sent to provincial papers and used quite extensively.... When the whole letter could not be used, the various papers have used the most interesting items, especially those which have a special interest to the people of the respective sections." ${ }^{\text {365 }}$ Through this process, these news items "were used in about twenty papers and parts of these letters were used in from twenty to fifty others." ${ }^{366}$ Among the clippings sent were more general news topics that involved the Scandinavian nations, such as American coal production and export to the neutrals. ${ }^{367}$ Others were of more personal and public interest, such as the election of the Norwegian-American Kristine Skerve Evans as California's first female justice, the celebration of a couple's golden wedding anniversary fifty years after their marriage in Ölmstad, Jönköping, Sweden, and the passing of a Swedish-American pastor born in Harbo Parish. ${ }^{368}$ Some also detailed the unique contributions of Swedish immigrants in the American war effort, such as one that named American veterans who were descendants of the Finnish-Swedish folk hero of the Finnish War (1808-9), Sven Dufva. ${ }^{369}$ In his letter, Palmer noted the effectiveness of these newsletters, stating "by this method many hundred thousand words about America have appeared in the Swedish press which would otherwise not have been published." ${ }^{370}$

In terms of more obvious forms of propaganda, Palmer sought out information regarding Scandinavian Americans participating in the armed forces. Early in May 1918, Palmer requested "statistics regarding Scandinavians [in the] army and navy," including the "names of officers if advisable." ${ }^{371}$ Two months later, Björkman indicated that "every effort" was being made to

\footnotetext{
${ }^{365}$ Eric H. Palmer to Edwin Björkman, February 26, 1919, entry 106, box 16, CPI.

${ }^{366}$ Eric H. Palmer to Edwin Björkman, undated, entry 106, box 16, CPI.

367 “Nytt från Amerika," Södersköpings Tidning, February 7, 1919, entry 106, box 16, CPI.

368 "Amerika-nyheter," Blekinge Folkblad, February 9, 1919, entry 106, box 16, CPI; "Från Amerika," Västerås Dagblad, February 4, 1919, entry 106, box 16, CPI.

369 "Från Amerika," Västerås Dagblad, February 4, 1919, entry 106, box 16, CPI.

${ }^{370}$ Eric H. Palmer to Edwin Björkman, February 26, 1919, entry 106, box 16, CPI.

${ }^{371}$ Eric H. Palmer to Committee on Public Information, May 4, 1918, file 103.93/231, box 732, CDF.
} 
obtain such information for him, though they were having some difficulty in doing so. ${ }^{372}$ In addition to statistical information, Palmer requested "photographs of Swedish-Americans in war activities." ${ }^{373}$ Lastly, Björkman forwarded Palmer "a series of letters from ScandinavianAmerican soldiers at the front" prepared in his office. ${ }^{374}$

In order to show the success and public influence of Swedish immigrants in the United States, the Scandinavian Bureau distributed material on leading Swedish-Americans. In his May letter, Palmer requested from Björkman a report on "Swedes in office throughout [the] United States." ${ }^{375}$ Among this material later sent by Björkman was likely a story on Swedish-American Minnesota Governor Joseph A. A. Burnquist, which Palmer noted "was generously used" by the Swedish press. ${ }^{376}$ In July, Björkman also began preparing feature stories “of brief, snappy biographies of our leading Swedish-Americans, illustrated by photographs taken by us for the purpose. We shall, of course, begin with men like John Lind and Chief Justice Olson," as they were prominent figures at the forefront of Swedish America's patriotic activities through the John Ericsson League. ${ }^{377}$

While the potential utility of Scandinavian-American news for shaping Scandinavian public opinion was an initial assumption, it did not go unquestioned. At the end of July 1918, Palmer completed a memorandum discussing the types of material "readily accepted" by the Swedish press, including stories on Swedish-Americans, agriculture, labor, industry, and war preparations. As for the Swedish-American news, Palmer stated that there was "a special interest, as might naturally be expected, in anything which Swedish-Americans are doing," however some

\footnotetext{
372 Edwin Björkman to Eric H. Palmer, July 3, 1918, entry 106, box 16, CPI.

${ }^{373}$ Eric H. Palmer to Edgar Sisson, July 30, 1918, entry 106, box 16, CPI.

${ }^{374}$ Edwin Björkman to Eric H. Palmer, August 20, 1918, entry 106, box 16, CPI.

${ }^{375}$ Eric H. Palmer to Committee on Public Information, May 4, 1918, file 103.93/231, box 732, CDF; Edwin Björkman to Eric H. Palmer, July 3, 1918, entry 106, box 16, CPI.

${ }^{376}$ Eric H. Palmer, "Memorandum for Foreign News Bureau, Committee on Public Information,” July 31, 1918, entry 106 , box 16 , CPI.

${ }^{377}$ Edwin Björkman to Eric H. Palmer, July 30, 1918, entry 106, box 16, CPI.
} 
of this material forwarded to him from Björkman was "recognized as propaganda pure and simple, and only the most friendly papers will accept it." The Swedish press's fear of foreign propaganda which might undermine their neutrality prevented some papers from publishing stories of Swedish-American's loyalty and patriotic activities in the United States. This being said, the press was nonetheless "only too eager" to publish "milder" Swedish-American content without overt pro-American sentiments. ${ }^{378}$

Two weeks later, Edwin Björkman sent out a memorandum concerning American cable news in Scandinavia following his own survey of the Scandinavian press. He concluded that:

a) The Scandinavian press stands indifferent to news that are important to ScandinavianAmericans but to no others.

b) To be interesting over there, Scandinavian-American news must be of general interest here [in the United States].

c) The patriotic appeal of any given piece of news here is rather against it over there.

d) News of general interest is vitiated by any injection of our own patriotic sentiments. ${ }^{379}$

Björkman derived this conclusion from his perception that the kind of ScandinavianAmerican material sent abroad has been "regarded with indifference or even hostility...except when we happen to touch some purely local basis of interest." For example, a story about a Swedish-American military officer would be met with "absolute indifference," but if it mentioned that he was from the city of Kalmar, the local papers would "become interested at once.” While Björkman acknowledged that there was a demand for Scandinavian-American news, he recommended to only use it when of "commanding importance" or "exceptional value." 380

\footnotetext{
${ }^{378}$ Eric H. Palmer, "Memorandum for Foreign News Bureau, Committee on Public Information," July 31, 1918, entry 106 , box 16 , CPI.

${ }^{379}$ Edwin Björkman, "American Cable News in Scandinavia," August 16, 1918, entry 105, box 4-5, CPI.

${ }^{380}$ Edwin Björkman, “American Cable News in Scandinavia," August 16, 1918, entry 105, box 4-5, CPI.
} 
This being said, one week later, Björkman wrote a follow-up memorandum on American cable news in Scandinavia after going through an additional batch of Danish papers. His conclusions remained "practically unaffected," though he did "admit a somewhat greater interest in Scandinavian-American news than I previously thought existed."381

Perhaps the most explicit examples of the demand for Swedish-American news in Sweden comes from a letter to Björkman from Palmer in January 1919. This letter contained select quotations from Swedish editors telling Palmer which kinds of material they want to publish. J. Svensson of Hallands Posten wrote "there are many people in these parts who have relatives in the great country in the west and on that account the interest in news and pictures is very great." J. A. Henricsson of Blekinge Folkblad echoed this sentiment, writing "many people have emigrated from our section of Sweden and their old friends and relations take a great interest in reading about America.” Appearing again, E. Wikmark of Sörmlandeposten wrote, "naturally it is with great interest we receive material pertaining to Swedish-Americans." As a final example, John Hansen of Östgöten wrote, "as you know there are in Sweden thousands of homes which are connected to 'the free country in the west' by blood relationship and therefore many reasons concur to awaken our sympathy for it." ${ }^{382}$

The quotations from the Swedish editors reveal that news about the activities of Scandinavian-Americans was not merely propaganda employed among the Swedish people due to an American assumption that it would be useful for influencing public opinion. While this was an initial assumption by American propagandists, Björkman questioned its utility. Palmer’s experience on the ground in Sweden and his Swedish contacts reinforced his belief that such material was useful. A demand for Swedish-American news came from below-that is, from

\footnotetext{
381 Edwin Björkman, “American Cable News in Scandinavian: II,” August 22, 1918, entry 105, box 4-5, CPI.

382 Eric H. Palmer to Edwin Björkman, January 7, 1919, entry 106, box 16, CPI.
} 
Swedes themselves possessing a desire to learn about the conditions of their friends and relatives abroad. This desire for Swedish-American news is further evidence of the personal transnational ties maintained between emigrants and those who stayed behind.

Scandinavian-American propaganda was never viewed as just another piece of propaganda, but rather was recognized as something unique and differentiated from the other material. In Palmer's final report, he stated how by the end of the war, "each week fully 100 papers were supplied with articles covering the activities of Swedish-Americans and dealing with subjects in which the people of the Scandinavian countries were chiefly interested." ${ }^{383}$ It is important to notice how Palmer singled out Scandinavian-American material from other subjects of interest.

${ }^{383}$ Eric H. Palmer to George Creel, May 27, 1919, entry 106, box 16, CPI. 


\section{CHAPTER XI: CONCLUSION}

The signing of the armistice on November 11, 1918 curtailed the work of the Committee on Public Information as well as Edwin Björkman's efforts to Americanize Swedish Americans and propagandize their countrymen abroad. Björkman's first initiative, the John Ericsson League of Patriotic Service, succumbed to a silent death in early 1919. In October 1918, Björkman's attention shifted to domestic work among the Dutch and Finns and to the propaganda work abroad, and therefore the role of national organizer and secretary for the JELPS passed onto Rev. Dr. Julius Lincoln of Los Angeles, California. ${ }^{384}$ While Björkman stated in his report for the month of November that the future of the league "promise[d] very well," Lincoln fell ill and resigned from his position on February 22, 1919, effectively marking the end of the JELPS's activities. ${ }^{385}$ News of his resignation reached the Swedish-American press in early April. Around this time, the press commented how the League had seemingly "died quietly" following the war's end. ${ }^{386}$ In June, after the closing of the Danish-American Jacob A. Riis League of Patriotic Service, also devised within Björkman's Bureau, the Swedish-American press noted how their own league "went quiet and still a few months ago, without any announcements in the newspapers regarding its death." ${ }^{387}$ Though the JELPS itself failed to survive through the peace conference, some of its more established partner organizations continued in their activities, such as the John Ericsson Republican League of Illinois and the John Ericsson League of Iowa, both of which changed their names to fall in line with Björkman's organization.

\footnotetext{
384 “Nyheter från John Ericsson League," Nordstjernan, October 11, 1918, 3.

385 Edwin Björkman, "Report on the work of the Scandinavian Bureau, from October 31 to November 26," November 29, 1918, entry 105, box 4-5, CPI; Edwin Björkman, "Report on the work of the Scandinavian Bureau from January 31 to March 1, 1919," March 3, 1919, entry 105, box 4-5, CPI. 386 “John Ericsson League of Patriotic Service," Svenska Pacific tribune, April 3, 1919, 8.

387 “Äfven Jacob A. Riis-ligan har nu afsomnat," Omaha-posten, June 25, 1919, 7. The Executive Committee of the Jacob A. Riis League of Patriotic Service circulated a letter to their members asking if the league should continue or not. The majority of responders voted to end it.
} 
The signing of the armistice largely precipitated the end of the Scandinavian Bureau's domestic work. Björkman explained in his report for February and March 1919 that his domestic service distributed one-fourth of the material to the Scandinavian-, Dutch-, and FinnishAmerican press in February than in January "due to the fact that a rather strict line had been drawn limiting the material to purely reconstruction work." 388 Björkman's office continued to produce information to be sent abroad to publicize the United States' position at the Paris Peace Conference until the Scandinavian Bureau's offices in Stockholm and Copenhagen closed on March 1, 1919.

Björkman's office staff, though without Björkman himself, was subsumed into another government organization, the postwar Foreign Language Information Service (FLIS). The difference between the FLIS and the CPI's Division of Work with the Foreign Born was in name only; its director remained Josephine Roche and the managers of the Scandinavian press sections were the same men employed by Björkman: H. Gude Grinndal for Sweden, Harry SundbyHansen for Norway, and Viggo C. Eberlin for Denmark. The FLIS maintained the same methods and goals of Roche's division in the CPI - to work with the foreign-language press to aid immigrants in the process of assimilation. Rather than steer the usual course of Americanization, which "insists that the immigrant conform, take on a sameness of customs and manners," Roche's new organization continued in the CPI's mission to encourage the immigrant to "participate with the native born in a common purpose of effective national unity and progress" through the dissemination of information necessary to becoming an American citizen. This

\footnotetext{
${ }^{388}$ Edwin Björkman, "Report on the work of the Scandinavian Bureau from January 31 to March 1, 1919," March 3, 1919 , entry 105 , box $4-5$, CPI.
} 
information was presented in their native languages and adjusted to their "particular difficulties," while also communicating to the "native born" their "contributions and needs." 389

The Scandinavian Bureau's foreign operations continued for the first two months of the Paris Peace Conference as "the means of interpreting views" of the United States for the Scandinavian press. ${ }^{390}$ The work was "gradually tapered down," "closely limited," and operated on a reduced budget. ${ }^{391}$ Björkman's orders were to close his Bureau's offices in Stockholm and Copenhagen on March $1 .{ }^{392}$ Palmer wrote to his superiors how the Scandinavian press "regretted the closing" of his office "at a time when it was greatly efficient and becoming increasingly strong" as well as when the Swedish press had entered a particularly "receptive mood" as a result of the Allied victory. ${ }^{393}$ In his final report, he quoted statements from Swedish American papers which "lauded the Committee for its work which the editors held had strengthened the bonds between the United States and Sweden.” Nya Dagliga Allehanda wrote how the CPI's articles had been printed to a "great extent" and had "served to dispel many of the old Swedish prejudices against the great country where so many of our fellow countrymen are so successfully laboring.” The conservative and pro-German paper Svenska Dagbladet wrote how the CPI had challenged the Germans in their distribution of "information and propaganda in foreign countries," but unlike that of Germany, "the American propaganda is quite open... The intention has been to develop and strengthen the connections between" Sweden and the United States. ${ }^{394}$

\footnotetext{
${ }^{389}$ Foreign Language Information Service, The Work of the Foreign Language Information Service: A Summary and Survey (New York: Foreign Language Information Service, 1921), 5-6.

${ }^{390}$ Edgar Sisson to Eric H. Palmer, November 5, 1918, entry 105, box 16-17, CPI.

${ }^{391}$ Edwin Björkman to Eric H. Palmer, January 3, 1918, file 103.93/1466L, box 735, CDF; Edwin Björkman to H. N. Rickey, January 25, 1919, entry 105, box 4-5, CPI.

392 Edwin Björkman, "Report on the work of the Scandinavian Bureau from January 31 to March 1, 1919," March 3, 1919 , entry 105, box 4-5, CPI.

${ }^{393}$ Eric H. Palmer to Edgar Sisson, April 1, 1919, entry 106, box 16-17, CPI; Eric H. Palmer to George Creel, May 27, 1919, entry 106, box 16-17, CPI.

${ }^{394}$ Eric H. Palmer to Edgar Sisson, April 1, 1919, entry 106, box 16-17, CPI; Eric H. Palmer to George Creel, May 27, 1919, entry 106, box 16-17, CPI.
} 
Palmer left Stockholm in mid-March to return to the United States, however he spent the journey in the ship's hospital, suffering from the Spanish flu. ${ }^{395} \mathrm{He}$ remarked in a letter to Sisson how he had had "but two days rest in a period covering almost a year, and I assure that during the stress of excitement that nervous strain was a considerable 'pull' on the system." ${ }^{\prime 396}$ Palmer reached American soil on March 31 in poor health and experienced further complications which plagued him for over two months. By mid-June Palmer entered a healthier state, "resuming some of his former activity, although twenty pounds lighter in weight." ${ }^{397}$

Both Edwin Björkman and Eric Palmer expressed how they regarded the Scandinavian Bureau's work abroad as a success. In January 1919, Björkman wrote how although it was perhaps too early to judge, he believed:

that the work of the Bureau has been distinctly successful. When the Bureau started, friendly and intelligent news items and articles relating to America were so scarce in the Scandinavian press as to be almost negligible in quantity. Months before the armistice was finally signed this situation had been completely changed and the United States was receiving an attention in the Scandinavian press that approached what we would regard as satisfactory. ${ }^{398}$

In a bold statement which George Creel would quote in his complete report, Björkman boasted that "To-day [sic] it is almost impossible to pick up a Scandinavian publication of any kind without finding references to America indicating an eager desire to understand what this country stands for and what it intends to do hereafter." 399

In May, Palmer became well enough to draft the final report of his activities in Scandinavia. In a preliminary letter to H. N Rickey, Palmer stated that he was "firmly convinced

\footnotetext{
395 “Mr. Eric H. Palmer sjuk,” Nordstjernan, April 25, 1919, 11.

${ }^{396}$ Eric H. Palmer to Edgar Sisson, April 1, 1919, entry 106, box 16-17, CPI

${ }^{397}$ The Chat (Brooklyn, New York), June 14, 1919, 73.

${ }^{398}$ Edwin Björkman, "Memorandum for Mr. Poole: Final Report from Mr. Edwin Björkman, Scandinavian Countries," January 10, 1919, entry 105, box 4-5, CPI.

${ }^{399}$ Edwin Björkman, "Memorandum for Mr. Poole: Final Report from Mr. Edwin Björkman, Scandinavian Countries," January 10, 1919, entry 105, box 4-5, CPI; United States Committee on Public Information and George Creel, The Creel Report, 133.
} 
that the Committee's work was of permanent value in establishing pleasant relationships between Sweden and the United States. ${ }^{400}$ In his final report a week later on May 27, 1919, Palmer explained the nature of the Scandinavian Bureau's success further. When his work began in early April 1918, American news in Scandinavia was limited, distorted, and came nearly exclusively via the German Wolff Telegraphic Bureau. According to his assessments, only three percent of news items in April discussed the United States, "and needless to say a good proportion were derogatory in their tone." Over time, especially "when the tide of battle turned" in the late summer, the previously hostile Swedish press began to use "column after column" of American news, "even of articles the character of which was pure propaganda could hardly be denied." By the time of the armistice, the German monopoly over the press, pictures, and film had been broken and Palmer's service "grew to striking importance," supplying some 100 papers each week. Judging from the nature of the material requested and published, Palmer believed that "early in the fall there was an increasing appreciation of the idealism of the President and the American people." ${ }^{\prime 401}$

This study of Edwin Björkman's work among Swedish Americans has illuminated the nature of the Committee on Public Information's work with immigrants. The CPI held a distinct liberal Progressive understanding of Americanization articulated by George Creel, Josephine Roche, and Edwin Björkman through their words and actions - speeches, writings, the structure of their organizations, and their activities. A central component of this understanding was a distinction between ethnic identity and political identity. To simply call Björkman and the CPI proponents of one hundred percent Americanism obscures this important distinction which

\footnotetext{
${ }^{400}$ Eric H. Palmer to H. N. Rickey, May 20, 1919, entry 106, box 16-17, CPI.

${ }^{401}$ Eric H. Palmer to Edgar Sisson, April 1, 1919, entry 106, box 16-17, CPI; Eric H. Palmer to George Creel, May 27, 1919, entry 106, box 16-17, CPI.
} 
separates them from the larger group of assimilationists. The CPI did not seek to erode ethnic affiliation, rather their actions consistently reinforced it by operating through existing ethnic leadership, organizations, using their native languages, emphasizing their contributions to the building of the United States, and encouraging contact with the Old Country. For the CPI, political loyalty to the United States—its government, democratic institutions, and ideals—did not necessitate abandoning one's cultural heritage and fully assimilating into the dominant Anglo-American culture. In fact, it was through the immigrant's native language, ethnic institutions, and leaders that they would most effectively come to integrate into American society and learn the duties of the citizen. By no means did an undivided loyalty imply the abandonment of Old World customs, traditions, or language. It is through this lens of cultural pluralism that Edwin Björkman's work under the Committee on Public Information must be understood. Björkman consistently conducted his work with an eye to the transnational relationships between Swedish-Americans and Swedes in Sweden. When the United States declared war on Germany in April 1917, the loyalties of Swedish Americans were suspect partially due to the pro-German sympathies of Sweden's conservative bureaucracy-there was a question of how Swedish Americans would react if Sweden joined the war on the side of Germany. It was therefore Björkman's mission to sever a political identification with the Swedish state and organize intense patriotic activity among Swedish Americans. News coming from Sweden held the pro-German biases built into the existing system of global communications, the German propaganda apparatus in Sweden, and the personal sympathies of Swedish editors. Because Swedish Americans maintained personal and emotional ties to Sweden, their opinions could be swayed by such news. Björkman took steps to control the flow of information coming from 
Scandinavia to the Scandinavian-American press by getting Scandinavian news first and providing a "correct" interpretation of events.

Swedish Americans were not only subjected to the CPI's Americanizing efforts, but also became subjects of propaganda sent abroad in stories of both their patriotic activities and everyday life. Björkman believed that just as Swedish Americans were influenced by social and political events in Sweden, Swedish Americans could influence public opinion in Sweden. This aspect of the CPI's work relied on transnational ties maintained between immigrants and the homeland. News stories, photos, and letters communicated Swedish Americans' loyalty to the United States, their support for its war aims, and the superiority of American ideals and democratic institutions to their friends and relatives in the Old Country. In this way, immigrants themselves were the channel through which the CPI disseminated Americanism. The purpose of this foreign work was to strengthen the relationship between Sweden and the United States, something in which immigrants were uniquely positioned to facilitate as a result of their hybrid Swedish-American identity. Revealing the salience of this transnational relationship, the Scandinavian Bureau's propaganda was not merely imposed upon Swedes in Sweden but was eagerly requested and consumed as they were interested in the lives and conditions of their emigrant countrymen.

While the Committee on Public Information attempted to promote cultural pluralism, in some capacities they fell short. One objective of the CPI's Division of Work with the Foreign Born was not only to Americanize immigrants, but also to educate native-born Americans about immigrants, their cultures, and their "gifts" to the United States. It is this aspect of the CPI's work with immigrants that even George Creel recognized as a failure. Attempts at such work included the dissemination of articles about immigrants in the English-language press and the 
Fourth of July celebration in New York, their largest public event which showcased immigrant cultures, songs, folk dress, sacrifices for the war effort, and contributions to the building of America. Despite these efforts, tolerance and an embrace of cultural pluralism failed to take root. In his memoir Rebel at Large, George Creel commented on this failure in the chapter "High Priest of Hate," a reference to the chauvinistic and nativist patriotic organizations the CPI stood against during the war. "The problem remains unsolved," he wrote, "there are still ghettos and foreign colonies walled off from their communities and viewed with either indifference or dislike. ... intolerance is far from dead in the land. ${ }^{402}$

Regarding the Scandinavian Bureau itself, a "Loyal Swedish-American" wrote a letter to the editor of Svea in September 1918 regarding the nature of Björkman's work. In response to articles written "'expressly' for the Swedish press in America," they asked, "Why not 'expressly' for the American press. ... The Swedish people have been roundly criticized as pro-Germans, and often by prejudiced editors, totally ignorant about the true conditions in Sweden." 403 Continuing their critique, they asked:

Is this "Scandinavian Bureau, Committee on Public Information" exclusively organized for the purpose of feeding the Scandinavian Press with what is considered the proper dope, or is it within their field or power to also provide the American Press with some truth in regard to the position that the Swedish people is taking in this world war? ${ }^{404}$

The anonymous author wrote that the Bureau had failed to accurately present the positions of Swedish Americans, dubbing it rather as a "Bureau of Public Misrepresentation." They then suggested that a "Scandinavian-American Bureau of Public Information" be created "to see that

\footnotetext{
${ }^{402}$ Creel, Rebel at Large, 201-2.

403 “Fria Uttalanden," Svea, September 11, 1918, 4.

404 “Fria Uttalanden," Svea, September 11, 1918, 4.
} 
the names of the Swedes abroad and on this side were not soiled unfairly and without recourse to justice and self-defense."405

It is possible to see Edwin Björkman's crusade for an undivided political loyalty among Swedish Americans as negatively impacting Swedish-American cultural identity, as some scholars of Scandinavian-American history have argued. Björkman participated in the antihyphenism of the period, claiming that Swedish Americans across the nation "hate the hyphen" and wanted to be known rather as "Americans of Swedish descent." ${ }^{406}$ He attacked the use of the Swedish flag, seeing it as a symbol of the Swedish state, and cancelled the Midsummer 1918 celebration due to its politicization.

There were cases where Swedish Americans reacted negatively to Björkman's work and perceived it as an unwarranted attack against their ethnic group. As Björkman was organizing local chapters of the JELPS, he received pushback from the Swedish Americans of Sioux City, IA, who thought that a mass meeting and patriotic organization in their city would imply disloyalty among them. Similarly, Svea reported poorly on Björkman's speech in Worcester, MA after he stated the fact that there were pro-German sentiments among some Swedish Americans. It is quite understandable that in a hostile nativist environment that Swedish Americans would become defensive in response to insinuations of their disloyalty.

This being said, Björkman cannot be framed solely as an Americanizer, seeking to expedite the assimilation of Swedish Americans into Anglo-American culture. He rather promoted a hybrid Swedish-American identity that put an American political identity first and Swedish cultural identity second. His work invoked Swedish-American homemaking myths of the heroic engineer John Ericsson and the colony of New Sweden. Swedish language, customs,

\footnotetext{
405 “Fria Uttalanden," Svea, September 11, 1918, 4.

406 "Predicts Sudden German Collapse Will Finish War,” Des Moines Register, March 13, 1918, 1.
} 
song, and dress were acceptable as long as one was an American citizen, spoke English, and examined world affairs as an American rather than a Swede. For the average Swedish American living in a period hostile to ethnic affiliation, however, the distinction between Björkman's work and the larger, less tolerant nationwide Americanization campaign could perhaps be lost.

The work of Edwin Björkman among Swedish Americans is but one case study regarding the Committee on Public Information's work among immigrants. The CPI had numerous bureaus working with other immigrant communities which have yet to be fully investigated, alongside the role immigrants played in the CPI's foreign propaganda to strengthen the relationship between the United States and the nations of the world. The full scope of the CPI's work in this capacity, its impact on ethnic identity in America, and its impact on wartime and interwar diplomacy have yet to be fully explored. 


\title{
BIBLIOGRAPHY
}

\author{
Abbreviations \\ CDF: Department of State, Decimal File, 1910-1929. Record Group 59, National Archives at \\ College Park, College Park, Maryland, United States \\ CPI: Committee on Public Information; Records of the Committee on Public Information, 1917- \\ 1919, Record Group 63, National Archives at College Park, College Park, Maryland, \\ United States
}

FLIS: Foreign Language Information Service

JELPS: John Ericsson League of Patriotic Service

NACP: National Archives, College Park, MD

NARA: National Archives and Records Administration

NPC: Nordiska Presscentralen (Nordic Press Center)

RG 111: Records of the Office of the Chief Signal Officer, 1860-1985, Record Group 111, National Archives at College Park, College Park, Maryland, United States

RG 165: Records of the War Department General and Special Staffs, 1860-1952, Record Group 165, National Archives at College Park, College Park, Maryland, United States

SvT: Svenska Telegrambyrån (Swedish Telegram Bureau)

\section{Primary Sources}

\section{Archival Collections}

Department of State, Decimal File, 1910-1929. Record Group 59. National Archives at College Park, College Park, Maryland, United States.

Edwin Björkman Papers, 1855-1954. \#3070. Southern Historical Collection, The Wilson Library, University of North Carolina at Chapel Hill. 
Gustav Andreen and Family Papers, MSS 4. Swenson Swedish Immigration Research Center Archives, Rock Island, Illinois.

Jules G. U. Mauritzson Papers, MSS 123. Swenson Swedish Immigration Research Center Archives, Rock Island, Illinois.

Nicolay Andreas Grevstad Papers, P 553. Norwegian American Historical Association Archives, Northfield, Minnesota.

Records of the Committee on Public Information, 1917-1919. Record Group 63. National Archives at College Park, College Park, Maryland, United States.

\section{Published Sources}

Björkman, Edwin. Gleams: A fragmentary Interpretation of Man and His World. New York: Mitchell Kennerley, 1912.

Björkman, Edwin. Gates of Life. New York: Alfred A. Knopf, 1923.

Björkman, Edwin. Is There Anything New Under the Sun? New York: Mitchell Kennerley, 1911.

Björkman, Edwin. “The New Swedish Cabinet.” American-Scandinavian Review 6, no. 1 (January-February 1918): 25-27.

Björkman, Edwin. Scandinavia and the War. London: Oxford University Press, 1914.

Björkman, Edwin. "Scandinavian Nations Against the Germans.” The Sun, January 3, 1915.

Björkman, Edwin. “Sweden's Position in the War.” In Scribner's Magazine, vol. 63, edited by Edward Livermore Burlingame, Robert Bridges, Alfred Sheppard Dashiell, and Harlan Logan, 213-218. New York City: Charles Scribner’s Sons, 1918.

Björkman, Edwin. “What is the Matter With Sweden?” In Everybody's Magazine 68, no. 4 (April 1918): 42-46. 
Björkman, Edwin. "What it Means to be a Small Neutral." In The World's Work 35, edited by Arthur W. Page, 437-447. Garden City, NY: Doubleday, Page \& Company, 1918. Björkman, Edwin. Voices of To-Morrow: Critical Studies of the New Spirit in Literature. New York: Mitchell Kennerley, 1913.

Creel, George. How We Advertised America; The First Telling of the Amazing Story of the Committee on Public Information that Carried the Gospel of Americanism to Every Corner of the Globe. New York and London: Harper \& Brothers, 1920.

Creel, George. Rebel at Large: Recollections of Fifty Crowded Years. New York: G.P. Putnam's Sons, 1947.

Link, Arthur S., ed. The Papers of Woodrow Wilson. Vols. 45-50. Princeton: Princeton University Press, 1984-85.

United States Committee on Public Information and George Creel. The Creel Report: Complete Report of the Chairman of the Committee on Public Information, 1917: 1918: 1919. Civil Liberties in American History. New York: Da Capo Press, 1972.

\section{Secondary Sources}

\section{Books}

Ahlund, Claes, ed. Scandinavia in the First World War: Studies in the War Experience of the Northern Neutrals. Lund: Nordic Academic Press, 2013.

Barton, H. Arnold. A Folk Divided: Homeland Swedes and Swedish Americans, 1840-1940. Carbondale: Southern Illinois University Press, 1994.

Blanck, Dag. The Creation of an Ethnic Identity: Being Swedish American in the Augustana Synod, 1860-1917. Carbondale: Southern Illinois University Press, 2006. 
Brøndal, Jørn. Ethnic Leadership and Midwestern Politics: Scandinavian Americans and the Progressive Movement in Wisconsin, 1890-1914. Northfield, MN: Norwegian-American Historical Association, 2004.

Chrislock, Carl Henry. Ethnicity Challenged: The Upper Midwest Norwegian-American Experience in World War I. Topical Studies 3. Northfield, MN: Norwegian-American Historical Association, 1981.

Hamilton, John Maxwell. Manipulating the Masses: Woodrow Wilson and the Birth of American Propaganda. Baton Rouge: Louisiana State University Press, 2020.

Higham, John, ed. Ethnic Leadership in America. Baltimore: John Hopkins University Press, 1978.

Higham, John. Strangers in the Land: Patterns of American Nativism, 1860-1925. New Brunswick: Rutgers University Press, 1988.

Jackson, Erika K. Scandinavians in Chicago: The Origins of White Privilege in Modern America. Urbana: University of Illinois Press, 2019.

Kennedy, David M. Over Here: The First World War and American Society. New York: Oxford University Press, 1980.

King, Desmond. Making Americans: Immigration, Race, and the Origins of the Diverse Democracy. Cambridge: Harvard University Press, 2000.

Lal, Barbara Ballis. The Romance of Culture in an Urban Civilization: Robert E. Park on race and ethnic relations in cities. New York: Routledge, 1990.

Lindmark, Sture. Swedish America, 1914-1932: Studies in Ethnicity with Emphasis on Illinois and Minnesota. Stockholm: Läromedelsförlaget, 1971. 
Mock, James R., and Cedric Larson. Words That Won the War: The Story of the Committee on Public Information, 1917-1919. Princeton: Princeton University Press, 1939.

Muncy, Robyn. Relentless Reformer: Josephine Roche and Progressivism in Twentieth-Century America. Princeton: Princeton University Press, 2014.

Nigro, Louis John, Jr.. The New Diplomacy in Italy: American Propaganda and U.S.-Italian Relations, 1917-1919. Studies in Modern European History 28. New York: Peter Lang, 1999.

Olson, Daron. Vikings Across the Atlantic: Emigration and the Building of a Greater Norway, 1860-1945. Minneapolis: University of Minnesota Press, 2013.

Riste, Olav. The Neutral Ally: Norway's Relations with Belligerent Powers in the First World War. Oslo, Universitetsforlaget, 1965.

Rossini, Daniela. Woodrow Wilson and the American Myth in Italy : Culture, Diplomacy, and War Propaganda. Harvard Historical Studies, 161. Cambridge: Harvard University Press, 2008.

Salmon, Patrick. Scandinavia and the Great Powers, 1890-1940. New York, N.Y., Cambridge University Press, 1997.

Vaughn, Stephen Holding Fast the Inner Lines: Democracy, Nationalism, and the Committee on Public Information. Chapel Hill: University of North Carolina Press, 1980.

Zeidel, Robert F. Immigrants, Progressives, and Exclusion Politics: The Dillingham Commission, 1900-1927. DeKalb: Northern Illinois University Press, 2004.

Øverland, Orm. Immigrant Minds, American Identities: Making the United States Home, 18701930. Urbana: University of Illinois Press, 2000. 


\section{Unpublished Dissertation}

Wolper, Gregg. "The Origins of Public Diplomacy: Woodrow Wilson, George Creel, and the Committee on Public Information.” PhD diss., University of Chicago, 1991.

\section{Articles and Chapters}

Blanck, Dag. "Constructing and Ethnic Identity: The Case of the Swedish-Americans." In The Ethnic Enigma: The Salience of Ethnicity for European-Origin Groups. Edited by Peter Kivisto. Philadelphia: The Balch Institute Press, 1989.

Blanck, Dag. "Scholars across the Seas: The American-Scandinavian Foundation and the Sweden America Foundation in the Trans-Atlantic Exchange of Knowledge.” American Studies in Scandinavia 40, no. 1-2 (2008): 110-125.

Blanck, Dag. "The Transnational Viking: The Role of the Viking in Sweden, the United States, and Swedish America." Journal of Transnational American Studies 7, no. 1 (2016): 1-19.

Blanck, Dag and Adam Hjorthén. "Transnationalizing Swedish-American Relations: An Introduction to the Special Forum." Journal of Transnational American Studies 7, no. 1 (2016)

Faist, Thomas. "Diaspora and Transnationalism: What Kind of Dance Partners?" In Diaspora and Transnationalism: Concepts, Theories, and Methods. Edited by Rainer Bauböck and Thomas Faist. Amsterdam: Amsterdam University Press, 2010.

Gjerde, Jon. "The Scandinavian Migration from Local and Transnational Perspectives." Journal of American Ethnic History 27, no. 2 (Winter, 2008): 85-90.

Hughes, Richard L. "Propaganda: Wilson and the Committee on Public Information." In $A$ Companion to Woodrow Wilson. Edited by Ross A. Kennedy. Chichester, West Sussex: Wiley-Blackwell, 2013. 
Kivisto, Peter. "Historians and Sociologists Debate Transnationalism." In The Oxford Handbook of American Immigration History. Edited by Ronald H. Bayor. New York: Oxford University Press, 2016.

Kivisto, Peter. "Theorizing transnational immigration: a critical review of current efforts." Ethnic and Racial Studies 24, no. 4 (July 2001): 549-577.

Olson, Daron W. "Norwegian-American Historians and the Creation of an Ethnic Identity." Scandinavian Studies 79, no. 1 (2007): 41-56.

Portes, Alejandro. "Introduction: The Debates and Significance of Immigrant Transnationalism." Global Networks 1, no. 3 (2001): 181-193.

Portes, Aejandro, Luis E. Guarnizo, and Patricia Landolt. "The Study of Transnationalism: Pitfalls and Promise of an Emergent Research Field.” Ethnic and Racial Studies 22, no. 2 (1999): 217-237.

Portes, Aejandro, Luis E. Guarnizo, and Patricia Landolt. “A Response to Janine Dahinden; Commentary on the Study of Transnationalism: Pitfalls and Promise of an Emergent Research Field.” Ethnic and Racial Studies 40, no. 9 (2017): 1486-1491.

Schiller, Nina Glick, Linda Basch, and Cristina Blanc-Szanton. "Transnationalism: A New Analytic Framework for Understanding Migration. Annals of the New York Academy of Sciences 645, no. 1 (July 1992): 1-24.

Thaler, Peter. "Concepts of Ethnicity in Early Twentieth-Century Norwegian America." Scandinavian Studies 69, no. 1 (1997): 85-103.

Wolper, Gregg. "Wilsonian Public Diplomacy: The Committee on Public Information in Spain." Diplomatic History 17, no. 1 (Winter 1993): 17-34. 